Prepared in collaboration with Ameren United Electric Company

\title{
Effects of the Upper Taum Sauk Reservoir Embankment Breach on the Surface-Water Quality and Sediments of the East Fork Black River and the Black River, Southeastern Missouri-2006-07
}

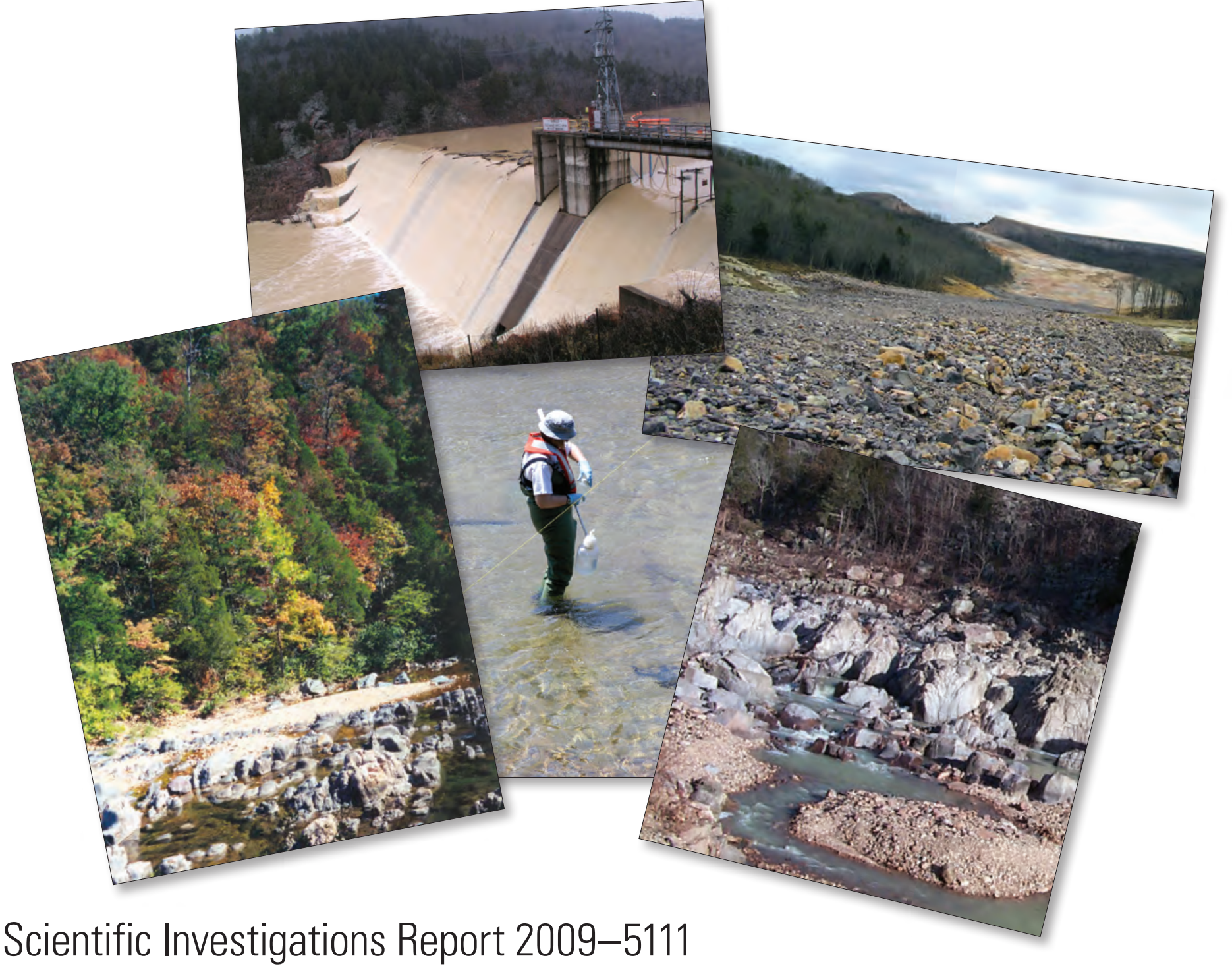

U.S. Department of the Interior

U.S. Geological Survey 


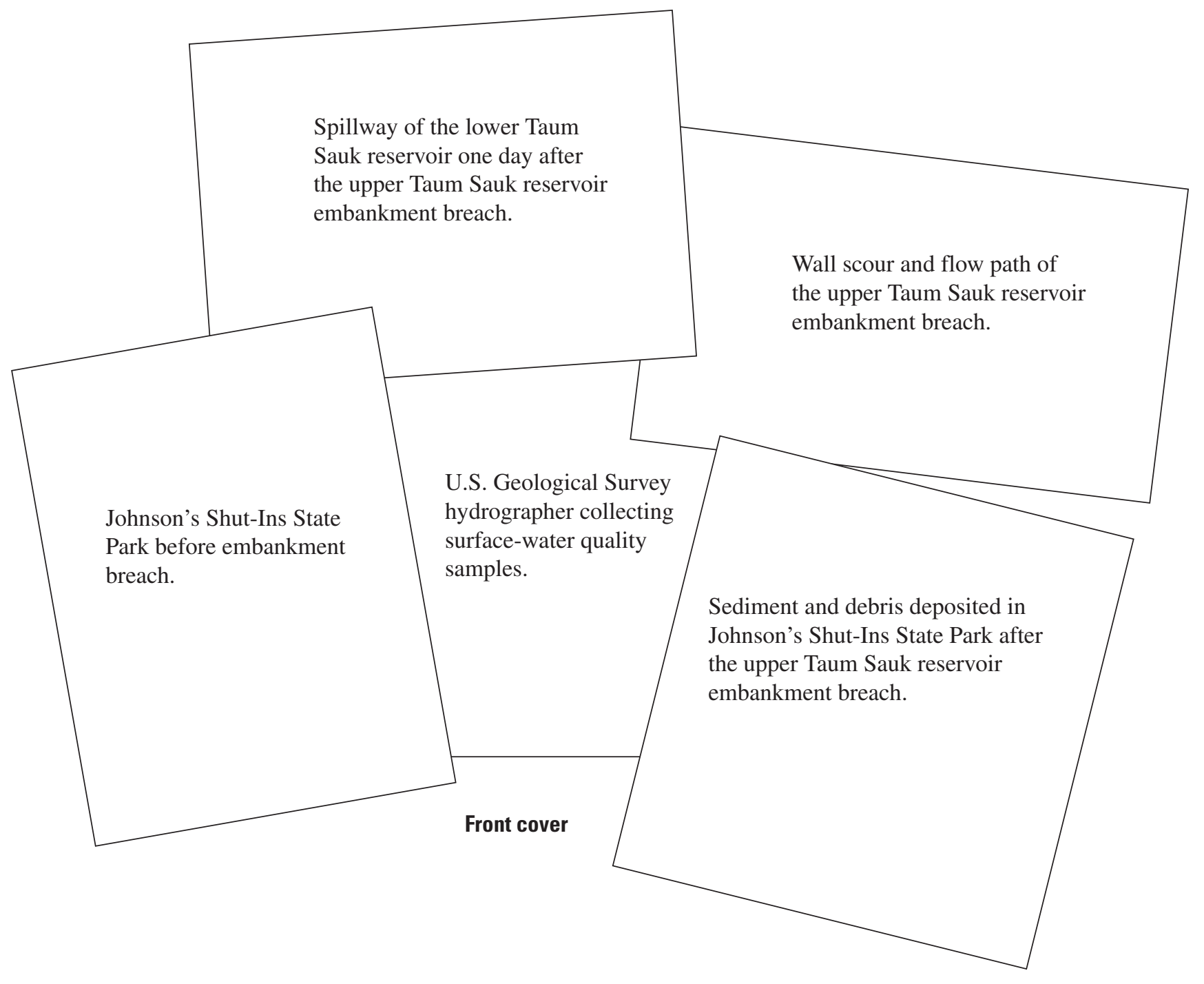




\section{Effects of the Upper Taum Sauk Reservoir Embankment Breach on the Surface- Water Quality and Sediments of the East Fork Black River and the Black River, Southeastern Missouri-2006-07}

By Miya N. Barr

Prepared in collaboration with Ameren United Electric Company

Scientific Investigations Report 2009-5111 


\title{
U.S. Department of the Interior \\ KEN SALAZAR, Secretary
}

\author{
U.S. Geological Survey \\ Suzette M. Kimball, Acting Director
}

U.S. Geological Survey, Reston, Virginia: 2009

For more information on the USGS - the Federal source for science about the Earth, its natural and living resources, natural hazards, and the environment, visit http://www.usgs.gov or call 1-888-ASK-USGS

For an overview of USGS information products, including maps, imagery, and publications, visit http://www.usgs.gov/pubprod

To order this and other USGS information products, visit http://store.usgs.gov

Any use of trade, product, or firm names is for descriptive purposes only and does not imply endorsement by the U.S. Government.

Although this report is in the public domain, permission must be secured from the individual copyright owners to reproduce any copyrighted materials contained within this report.

Suggested citation:

Barr, M.N., 2009, Effects of the Upper Taum Sauk reservoir embankment breach on the surface-water quality and sediments of the East Fork Black River and the Black River, southeastern Missouri-2006-07: U.S. Geological Survey Scientific Investigation Report 2009-5111, 59 p. 


\section{Contents}

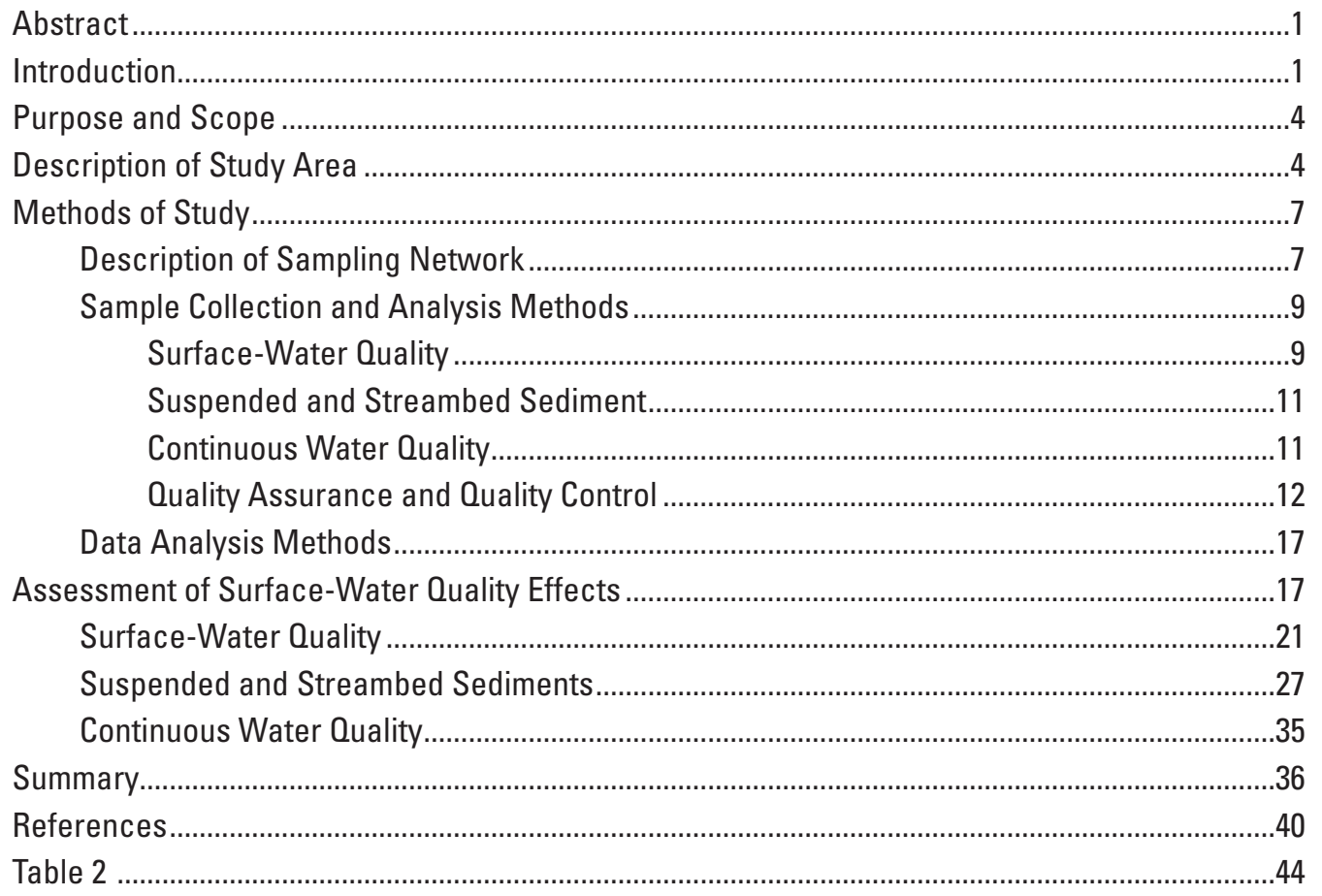

\section{Figures}

1. Map showing location of study area............................................................................

2. Aerial photograph showing location of Johnson's Shut-Ins State Park boundary and Taum Sauk pump-storage hydroelectric power plant facility .....................................

3-5. Photographs showing-

3. Rhyolite formations in Johnson's Shut-Ins State Park..............................................

4. Flood damage and flow path during upper Taum Sauk reservoir embankment

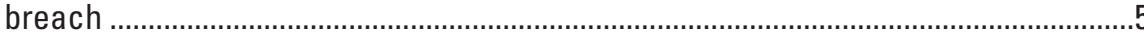

5. Damage to the western slope of Proffit Mountain during the upper Taum Sauk reservoir embankment breach

6-7. Graphs showing-

6. Departure from average monthly precipitation, January 2006 through December 2007

7. Daily precipitation recorded at two U.S. Geological Survey streamflow-gaging stations, January 2006 through December 2007

8-10. Photographs showing-

8. A U.S. Geological Survey hydrographer collecting a discrete surface-water quality sample using the equal-width increment (EWI) method

9. U.S. Geological Survey hydrographers collecting daily suspended-sediment samples from automatic sampler

10. Water-quality monitor used to measure field properties. 
11-13. Graphs showing-

11. Comparison of continuous data, cross-section measurements, and streamflow from East Fork Black River near Lesterville, Missouri, January 2006 through December 2007

12. Comparison of continuous data, cross-section measurements, and streamflow from East Fork Black River at Lesterville, Missouri, January 2006 through December 2007

13. Comparison of continuous data, cross-section measurements, and streamflow from Black River below Annapolis, Missouri, January 2006 through December 2007

14. Example of a boxplot.

15-16. Box plots showing-

15. Streamflow, general water-quality, trace elements, and suspendedsediment concentrations for three sampling sites, January 2006 through December 2007

16. Seasonal trends of discrete surface-water quality cross-section data for turbidity, dissolved and total recoverable aluminum, and suspendedsediment concentrations at sites 1 and 2, January 2006 through December 2007

17-19. Graphs showing-

17. Correlation plots of various surface-water quality constituents

18. Comparison of surface-water quality constituents with streamflow, January 2006 through December 2007

19. Suspended-sediment discharge in relation to daily mean streamflow, January 2006 through December 2007.

20-21. Box plots showing-

20. Streamflow, suspended-sediment concentration, and suspendedsediment discharge from Black River below Annapolis, Missouri, 1993-95 and 2006-07.

21. Suspended-sediment concentration data from Black River below Annapolis, Missouri, May 1993 through December 2007.

22. Photographs of selected stream reaches

23. Box plot showing monthly median values for streamflow, continuous waterquality constituents, and suspended-sediment concentrations 


\section{Tables}

1. Analytical methods and method reporting levels used by the U.S. Geological Survey National Water Quality Laboratory .. 10

2. Surface-water quality data, January 2006 through December 2007

3. Calibration criteria, correction criteria, maximum allowable limits, and ratings of accuracy for continuous water-quality monitor data .

4. Cross-section physical property measurements, continuous water-quality monitor (CWOM) data, and automatic sampler data collected within the same hour, January 2006 through December 2007

5. Summary statistics for selected physical properties, inorganic constituents, nutrients, and trace metals in the East Fork Black River and Black River, January 2006 through December 2007

6. Results of inductively coupled argon plasma-mass spectrometry of suspended sediment collected during storm events and streambed sediment collected during low-flow periods.

7. Results of sediment particle-size analyses of streambed sediments used in inductively coupled argon plasma-mass spectrometry analyses 


\section{Conversion Factors and Datums}

\begin{tabular}{lcl}
\hline \multicolumn{1}{c}{ Multiply } & By & \multicolumn{1}{c}{ To obtain } \\
\hline foot $(\mathrm{ft})$ & Length & \\
mile (mi) & 0.3048 & meter $(\mathrm{m})$ \\
& 1.609 & kilometer $(\mathrm{km})$ \\
\hline acre & Area & \\
square mile $\left(\mathrm{mi}^{2}\right)$ & 4,047 & square meter $\left(\mathrm{m}^{2}\right)$ \\
& 2.590 & square kilometer $\left(\mathrm{km}^{2}\right)$ \\
\hline gallon $($ gal) & Volume & \\
acre-foot $($ acre-ft) & 3.785 & liter $(\mathrm{L})$ \\
\hline & 1,233 & cubic meter $\left(\mathrm{m}^{3}\right)$ \\
\hline inch per year $(\mathrm{in} / \mathrm{yr})$ & Flow rate & \\
cubic foot per second $\left(\mathrm{ft}^{3} / \mathrm{s}\right)$ & 25.4 & millimeter per year $(\mathrm{mm} / \mathrm{yr})$ \\
\hline & 0.02832 & cubic meter per second $\left(\mathrm{m}^{3} / \mathrm{s}\right)$ \\
\hline ton per day (ton/d) & Mass & \\
\hline
\end{tabular}

Temperature in degrees Celsius $\left({ }^{\circ} \mathrm{C}\right)$ may be converted to degrees Fahrenheit $\left({ }^{\circ} \mathrm{F}\right)$ as follows:

$$
{ }^{\circ} \mathrm{F}=\left(1.8 x^{\circ} \mathrm{C}\right)+32
$$

Temperature in degrees Fahrenheit $\left({ }^{\circ} \mathrm{F}\right)$ may be converted to degrees Celsius $\left({ }^{\circ} \mathrm{C}\right)$ as follows:

$$
{ }^{\circ} \mathrm{C}=\left({ }^{\circ} \mathrm{F}-32\right) / 1.8
$$

Vertical coordinate information is referenced to the North American Vertical Datum of 1988 (NAVD 88).

Horizontal coordinate information is referenced to the North American Datum of 1983 (NAD 83).

Specific conductance is given in microsiemens per centimeter at 25 degrees Celsius $(\mu \mathrm{S} / \mathrm{cm}$ at $\left.25^{\circ} \mathrm{C}\right)$.

Concentrations of chemical constituents in water are given either in milligrams per liter (mg/L) or micrograms per liter $(\mu \mathrm{g} / \mathrm{L})$.

Water year in U.S. Geological Survey reports dealing with surface-water supply is the 12 -month period October 1 through September 30 . The water year is designated by the calendar year in which it ends and which includes 9 of the 12 months. Thus, the year ending September 30, 2007, is called the "2007 water year". 


\title{
Effects of the Upper Taum Sauk Reservoir Embankment Breach on the Surface-Water Quality and Sediments of the East Fork Black River and the Black River, Southeastern Missouri-2006-07
}

\author{
By Miya N. Barr
}

\section{Abstract}

On December 14, 2005, a 680-foot wide section of the upper reservoir embankment of the Taum Sauk pump-storage hydroelectric powerplant located in Reynolds County, Missouri, suddenly failed. This catastrophic event sent approximately 1.5 billion gallons of water into the Johnson's Shut-Ins State Park and into the East Fork Black River, and deposited enormous quantities of rock, soil, and vegetation in the flooded areas. Water-quality data were collected within and below the impacted area to study and document the changes to the riverene system. Data collection included routine, eventbased, and continuous surface-water quality monitoring as well as suspended- and streambed-sediment sampling. Surface water-quality samples were collected and analyzed for a suite of physical and chemical constituents including: turbidity; nutrients; major ions such as calcium, magnesium, and potassium; total suspended solids; total dissolved solids; trace metals such as aluminum, iron, and lead; and suspended-sediment concentrations. Suspended-sediment concentrations were used to calculate daily sediment discharge. A peculiar blue-green coloration on the water surface of the East Fork Black River and Black River was evident downstream from the lower reservoir during the first year of the study. It is possible that this phenomenon was the result of "rock flour" occurring when the upper reservoir embankment was breached, scouring the mountainside and producing extremely fine sediment particles, or from the alum-based flocculent used to reduce turbidity in the lower reservoir. It also was determined that no long-term effects of the reservoir embankment breach are expected as the turbidity and concentrations of trace metals such as total recoverable aluminum, dissolved aluminum, dissolved iron, and suspended-sediment concentration graphically decreased over time. Larger concentrations of these constituents during the beginning of the study also could be a direct result of the alum-based flocculent used in the lower reservoir. Suspendedsediment concentrations and turbidity measurements were largest at the site downstream from the lower reservoir. This is because of the large amounts of debris deposited in the lower reservoir from the breach, which in turn were redeposited into the East Fork Black River during releases. When these constituents were plotted over time, the concentrations decreased and were similar to the other two sites in the study. Trend analyses were studied at one site with historical data. No major trends were discovered for streamflow, turbidity, suspended-sediment concentrations, or suspended-sediment discharges before or after the event. Although long-term effects of the elevated turbidity, major trace metals, and suspended sediments in the study area as a result of the reservoir embankment breach are not expected, there could possibly be other effects not measured during this study that could potentially affect the surface-water quality, such as loss of riparian habitat, changes in biological ecosystems, and large-scale reworking of sediments.

\section{Introduction}

The Taum Sauk pump-storage hydroelectric powerplant, owned and operated by Ameren United Electric (UE) Company, was completed in July 1963 and went into commercial operation in December 1963. The powerplant, named "Taum Sauk" after an Indian chief who once ruled tribes in the area, utilized reversible turbines that operated as pumps and hydroelectric generators. The turbines used power from other electric powerplants to pump water from a lower reservoir to an upper reservoir on top of 1,590-foot (ft) high Proffit Mountain during "off-peak" hours such as nights and weekends. When electricity demand was high, the pumping process was reversed and the pumps became turbine-generators as water was released from the upper reservoir to the lower reservoir through a 7,000-ft tunnel, producing electricity in the same manner as a conventional hydroelectric powerplant (Rydlund, 2006).

Johnson's Shut-Ins State Park, managed by the Missouri Department of Natural Resources (MDNR), is located along the East Fork Black River adjacent to Proffit Mountain (figs. 1, 2). The "shut-ins" within the State park boundary are approximately 1 mile (mi) downstream from State Highway N. The term "shut-ins" is used to describe narrow, steep-sided gorges 


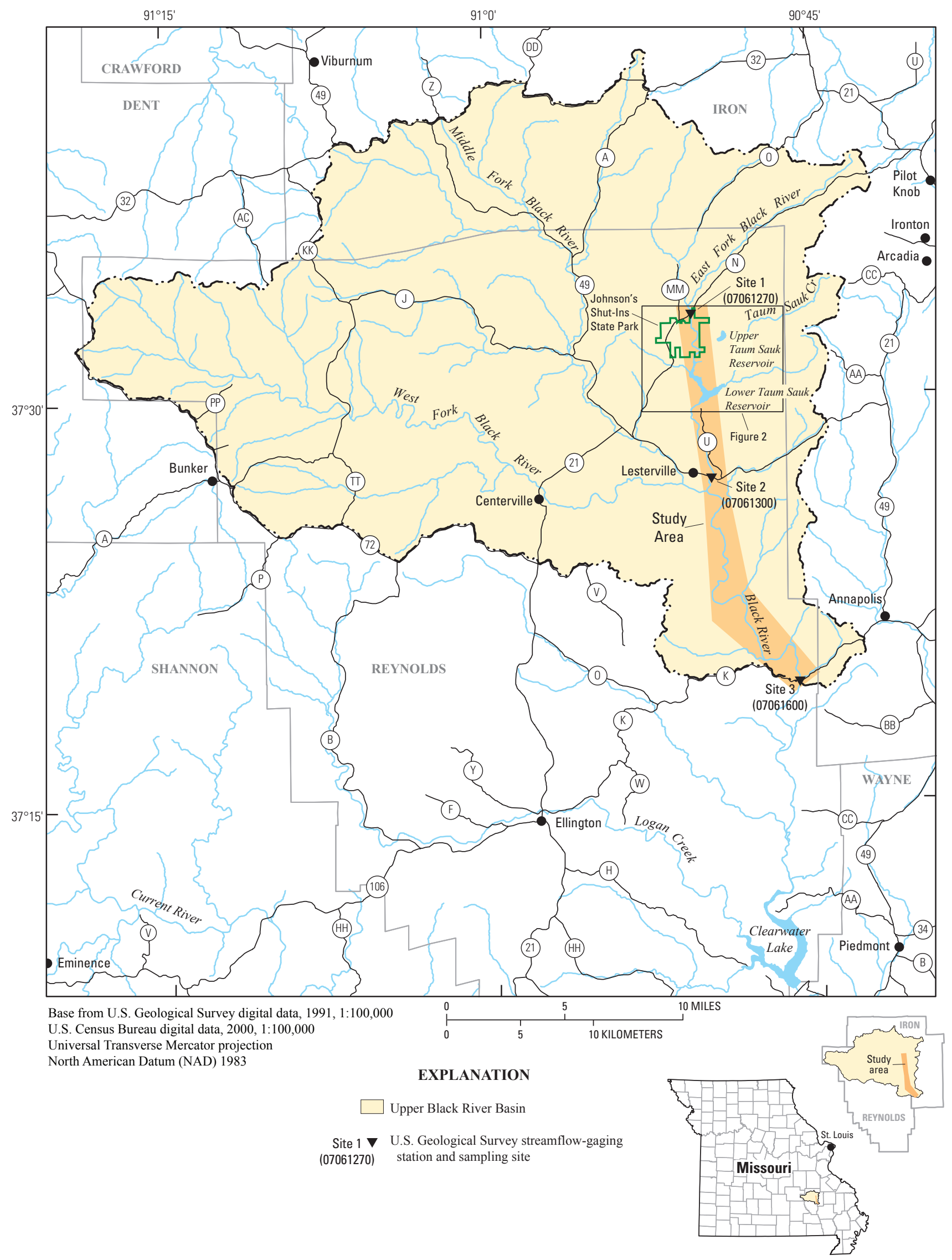

Figure 1. Location of study area. 


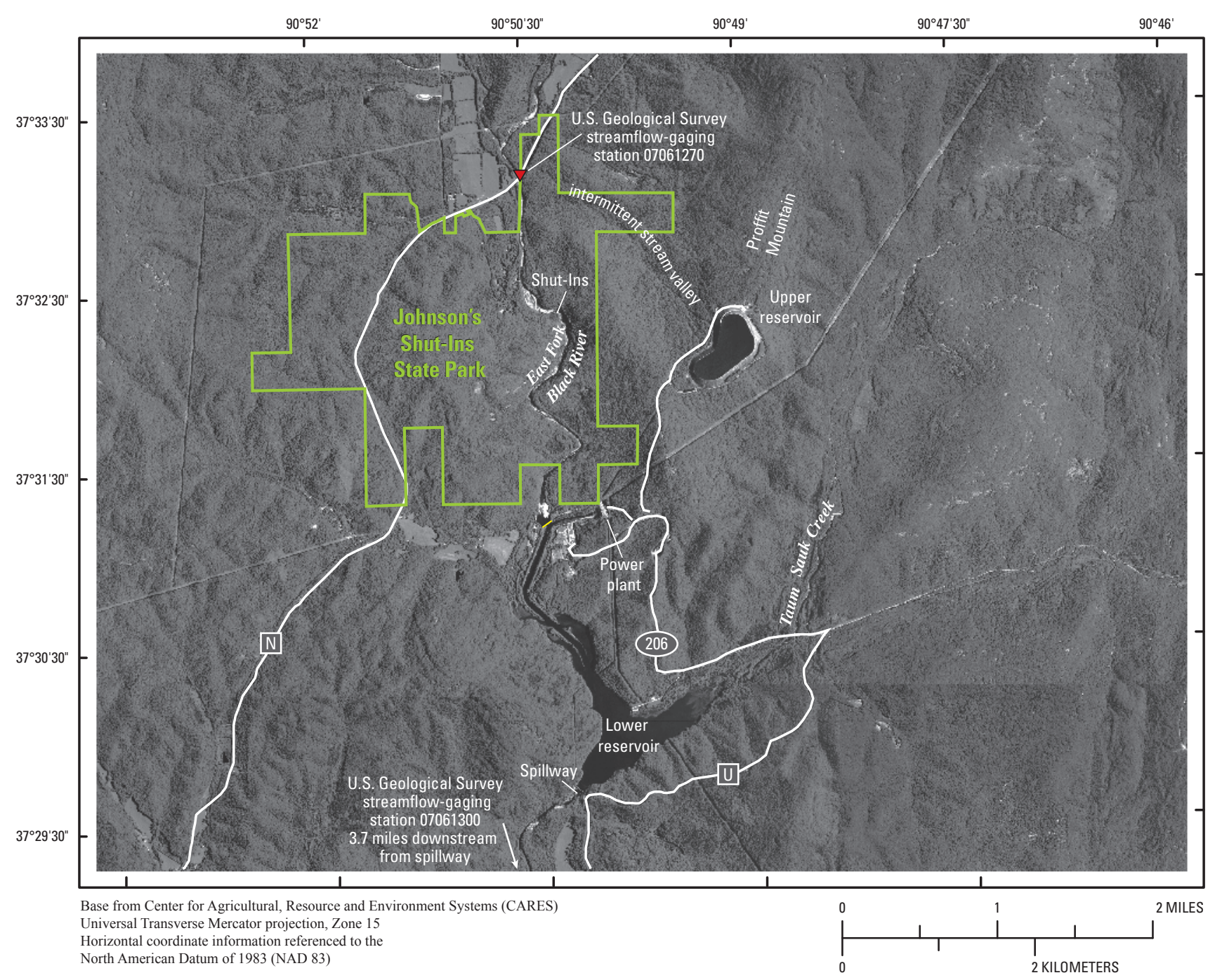

Figure 2. Location of Johnson's Shut-Ins State Park boundary and Taum Sauk pump-storage hydroelectric power plant facility.

along the course of an otherwise wide and shallow stream valley where a river becomes confined, or "shut-in," to a narrow channel. Erosion of the exposed rhyolite bedrock produced unique formations such as gorges, chutes, and potholes throughout the state park (fig. 3). Johnson's Shut-Ins is one of the most popular parks in Missouri, with nearly 250,000 annual visitors (River Valley Region Association, 2008).

At 5:16 a.m. on December 14, 2005, the embankment of the 55-acre upper reservoir failed. Overfilling during the "off peak" pumping cycle resulted in a 680 -ft wide embankment breach, which caused approximately 1.5 billion gallons of water to spill down a steep intermittent stream valley along the western side of Proffit Mountain into and across the East Fork Black River (fig. 2). The flood wave occurred within 25 minutes of the embankment breach (Hendron and others, 2006).

At the base of Proffit Mountain, the flood wave parted when it impacted the western valley wall of the East Fork Black River. The flood wave, which flowed upstream, removed a residential structure from the foundation, washed a tractor-trailer truck off State Highway N, and damaged a U.S. Geological Survey
(USGS) streamflow-gaging station (hereinafter referred to as gaging station) located at the State Highway N crossing of East Fork Black River (fig. 4). The gaging station recorded the last stage measurement at 5:15 a.m. on December 14, 2005. The force of the flood wave stripped overburden from the western slope of Proffit Mountain, exposed bedrock (fig. 5) and deposited clay, silt, sand, gravel, and woody debris along the East Fork Black River from State Highway N to the lower reservoir. The deposited sediments ranged from approximately 0.5 to $3 \mathrm{ft}$ thick. The volume of area affected by the flood deposits ranged from approximately 133,000 to $2,700,000$ acre-ft (Rydlund, 2006).

Floods of large magnitude, such as the one produced by the embankment failure, disrupt ecological and fluvial systems by altering channel configurations, substrate, and sediment discharge and present unique opportunities to analyze and document flood effects on water quality within the surrounding watershed. To address this opportunity, the USGS in collaboration with Ameren United Electric Company conducted a study in 2006 and 2007 on the East Fork Black River and a 


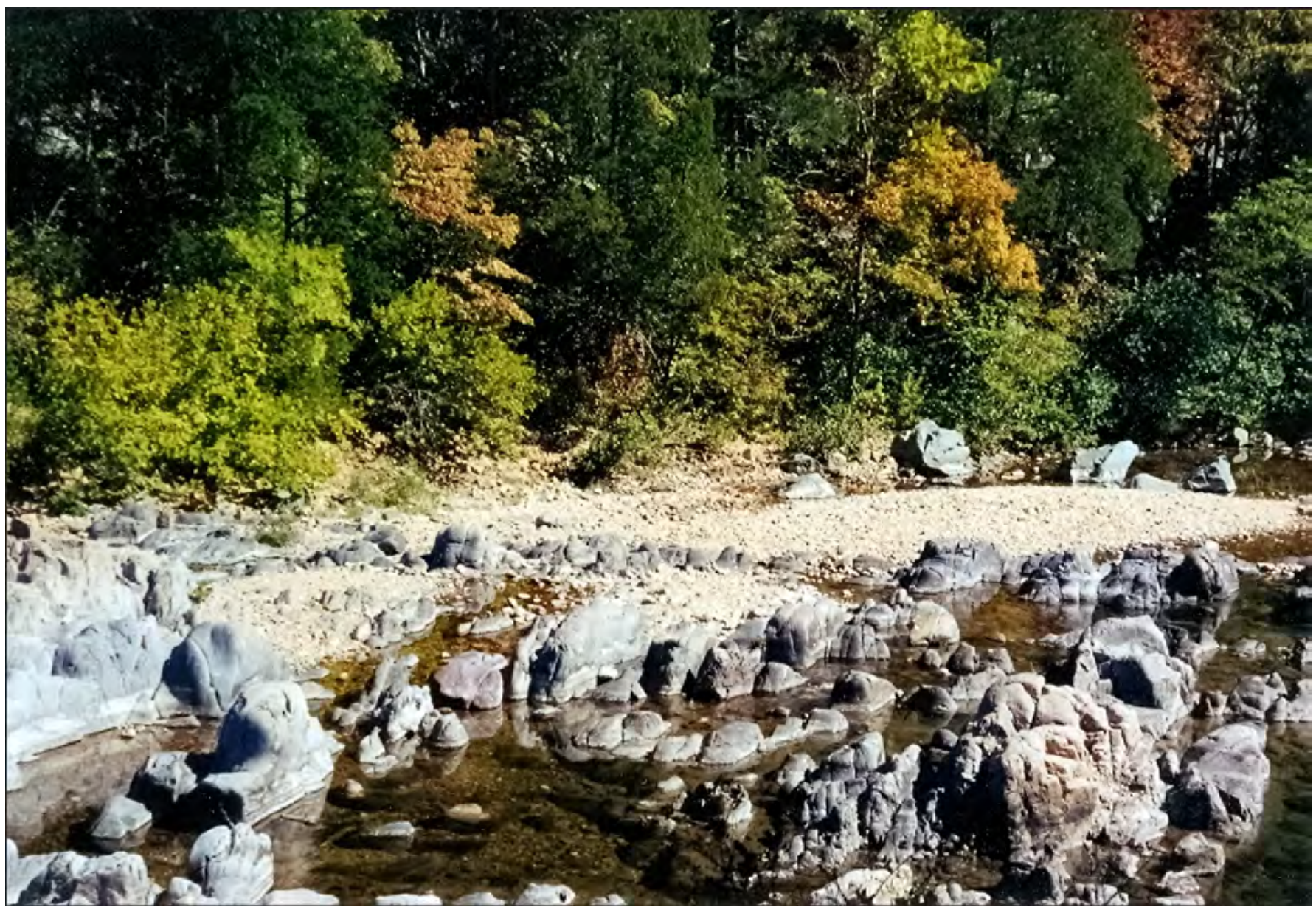

Figure 3. Rhyolite formations in Johnson's Shut-Ins State Park.

downstream Black River site to monitor the changes in water quality resulting from the embankment failure.

\section{Purpose and Scope}

The purpose of this report is to evaluate environmental effects that occurred in the East Fork Black River and the Black River in response to the breach of the upper Taum Sauk reservoir embankment. Surface-water quality, continuous water-quality, and sediment data were collected from January 2006 through December 2007. Physical properties were collected every 15 minutes, transmitted hourly, and displayed publically by the National Water Information System website (NWISWeb, http://waterdata.usgs.gov/nwis).

\section{Description of Study Area}

The Taum Sauk pump-storage hydroelectric powerplant is located in Reynolds County, Missouri, approximately $5 \mathrm{mi}$ north of Lesterville and approximately $90 \mathrm{mi}$ southwest of St. Louis (fig. 1). The study area is located in the Ozark Plateaus physiographic province (Fenneman, 1938). The study area is heavily wooded, and has steep, rugged topography with narrow valleys, dendritic drainages, and main channel gradients steeper than most channels in Missouri. Elevations in this region range from about 800 to $1,700 \mathrm{ft}$ (Alexander and Wilson, 1995). The upper reservoir, on top of Proffit Mountain, has an average basin bottom elevation of approximately 1,505 $\mathrm{ft}$. The lower reservoir is at the junction of the East Fork Black River and Taum Sauk Creek (fig. 2; Rydlund, 2006).

The northern part of the study area is in the St. Francois Mountains. The St. Francois Mountains are an area of about 1,000 square miles $\left(\mathrm{mi}^{2}\right)$ composed of exposed Precambrian igneous knobs and valleys underlain by Paleozoic sedimentary rocks, such as dolomite and sandstone (Fenneman, 1938).

Many streams in the St. Francois Mountains flow on Paleozoic rocks in valleys between the igneous knobs. At Johnson's Shut-Ins State Park, however, the East Fork Black River flows on and has eroded the harder exposed Precambrian granite and rhyolite, creating the canyon-like gorges known as "shut-ins" or "narrows" (Hayes and Beveridge, 1961).

Population in the study area is sparse, approximately 25 persons per square mile (University of Missouri, 2001). Land use is primarily forested with some grazing pastures for livestock (Missouri Spatial Data Information Service, 2005). 


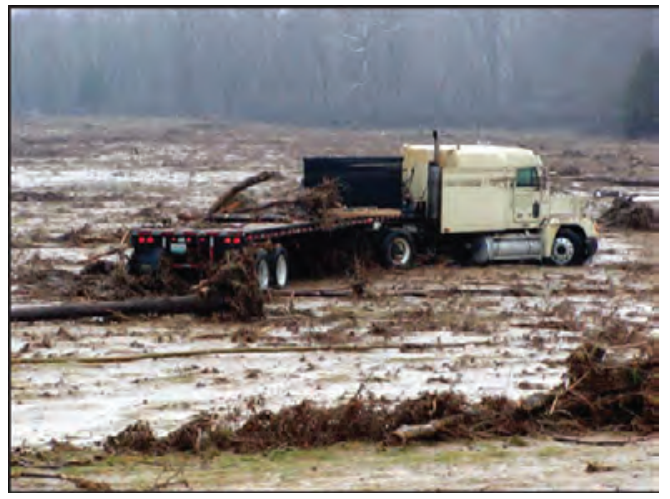

Tractor-trailer truck washed off State Highway N (photograph courtesy of Ken Beck, Reynolds County Courier, 2005).

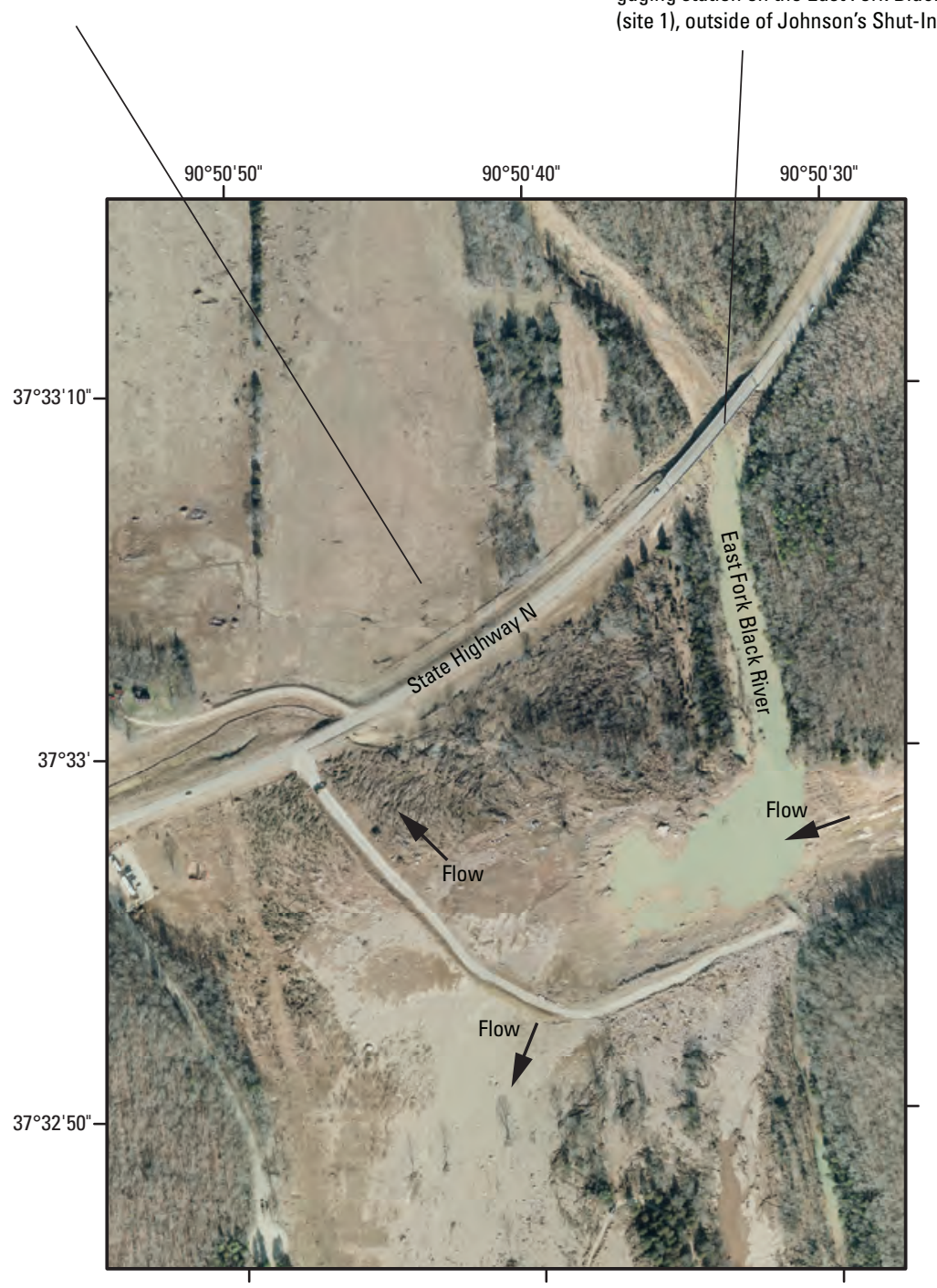

Base from Surdex Inc, proprietary to MacTec Engineering and Consulting Inc.

One-half foot pixel resolution, January 2006

Universal Transverse Mercator projection, Zone 15

Horizontal coordinate information referenced to the

North American Datum of 1983 (NAD 83)

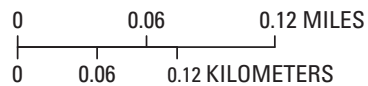

Figure 4. Flood damage and flow path during upper Taum Sauk reservoir embankment breach. 


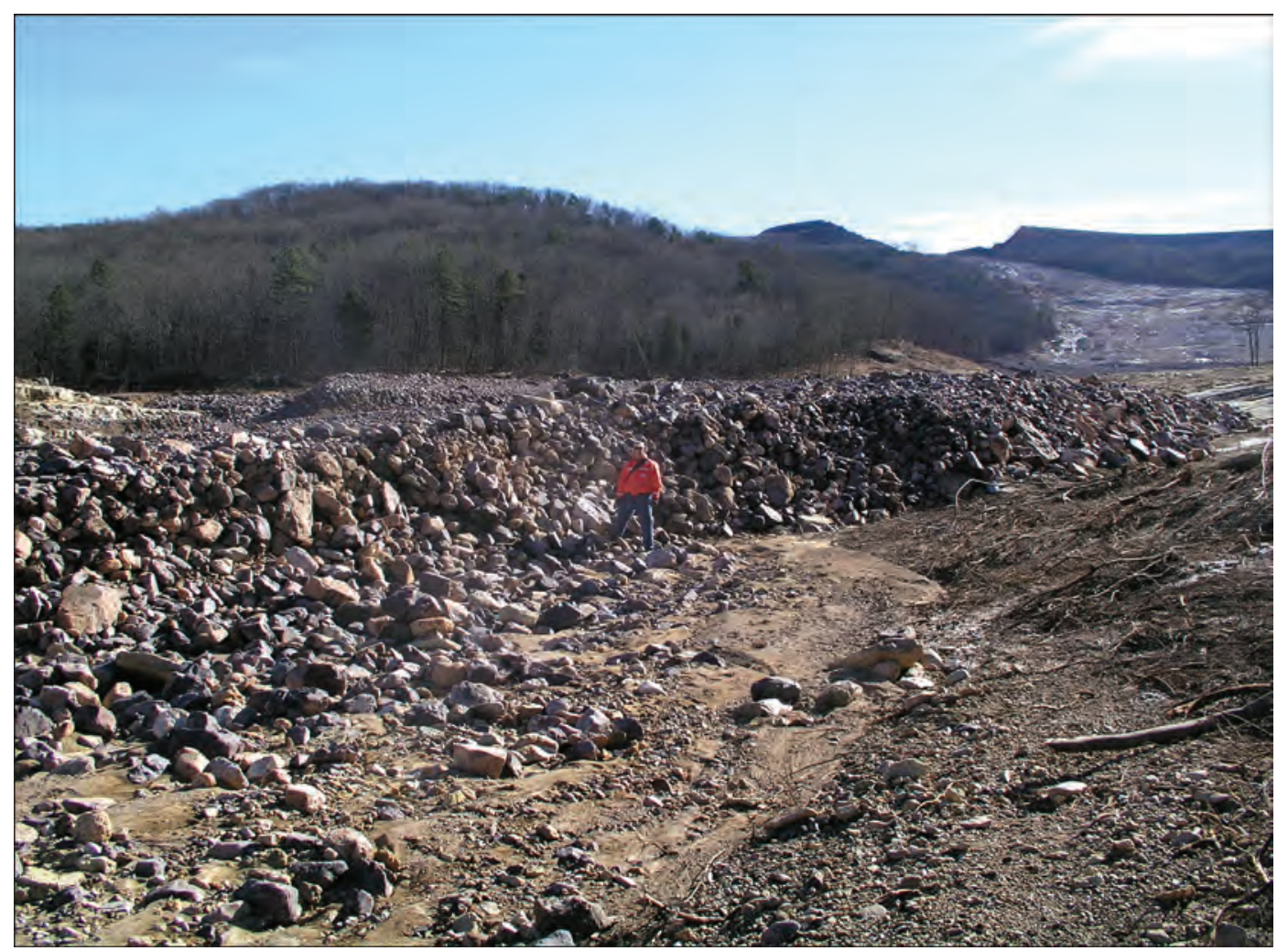

View looking upstream from the flood path towards the upper reservoir.

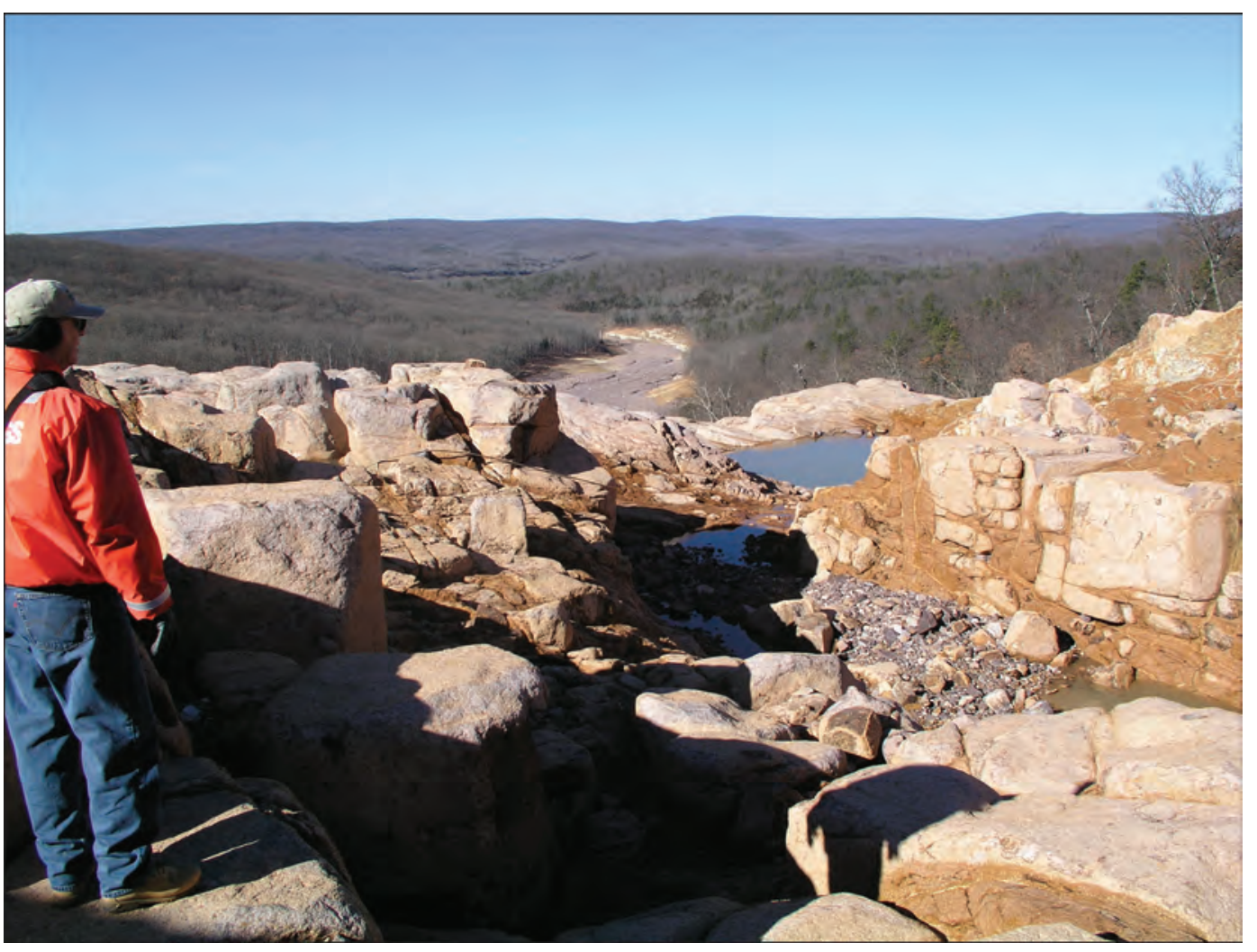

View from upper reservoir looking downstream along the flood path.

Figure 5. Damage to the western slope of Proffit Mountain during the upper Taum Sauk reservoir embankment breach. 
The study area has a temperate climate with average annual precipitation of approximately 40 inches per year (in/ yr) and a mean annual air temperature of 60 degrees Fahrenheit ( ${ }^{\circ} \mathrm{F}$; National Oceanic and Atmospheric Administration, 2006, 2007). Bunker, Missouri, approximately $30 \mathrm{mi}$ west of the study area, and Arcadia, Missouri, approximately 15 mi east of the study area, are the two nearest climatological stations (fig. 1). Monthly precipitation during the study period (January 2006 through December 2007), generally was below average at Bunker and Arcadia (fig. 6; National Oceanic and Atmospheric Administration, 2006, 2007). Average monthly precipitation values for the study area were calculated from monthly precipitation data available for the two climatological stations. Daily precipitation data were recorded at two USGS gaging stations during the study period (USGS identifiers 07061300 and 07061600 ; fig. 7).

\section{Methods of Study}

To determine the effects of the Taum Sauk reservoir embankment breach on surface-water quality, a network of three sampling sites were established at the USGS gaging stations. The sampling network included discrete surface-waterquality samples, suspended-sediment and streambed-sediment samples, and continuous surface-water quality monitoring.

\section{Description of Sampling Network}

An existing gaging station, East Fork Black River near Lesterville at State Highway N (USGS identifier 07061270; fig. 1), was used to provide baseline data for the East Fork Black River. The gage is located upstream from Johnson ShutIns State Park, approximately 1/8 mi outside the park entrance, and has been in operation from October 2001 to September 2002, and from October 2003 to the current year (2008). The maximum recorded water-surface elevation of 838.6 $\mathrm{ft}$ occurred May 12, 2002, and the mean annual streamflow recorded for the period of record is 70.4 cubic feet per second $\left(\mathrm{ft}^{3} / \mathrm{s}\right)$ (U.S. Geological Survey, 2007).

Construction was ongoing during the study period in Johnson's Shut-Ins State Park to repair damages from the embankment breach. Extensive construction was performed to repair the East Fork Black River stream reach that flows through the park. MDNR began restoring the East Fork Black River in early 2007 to its original flow path by constructing point bars, high stream banks, and stream bends, to recreate typical eastern Ozark stream features (Missouri Department of Natural Resources, 2008).

To monitor effects of the flood on the lower Taum Sauk reservoir after the embankment failure, a discontinued gaging station was reactivated in January 2006 on the East Fork Black River at Lesterville (USGS identifier 07061300; fig. 1) on State Route 21. This site previously was operated as a gaging station from January 1960 through September 1990.

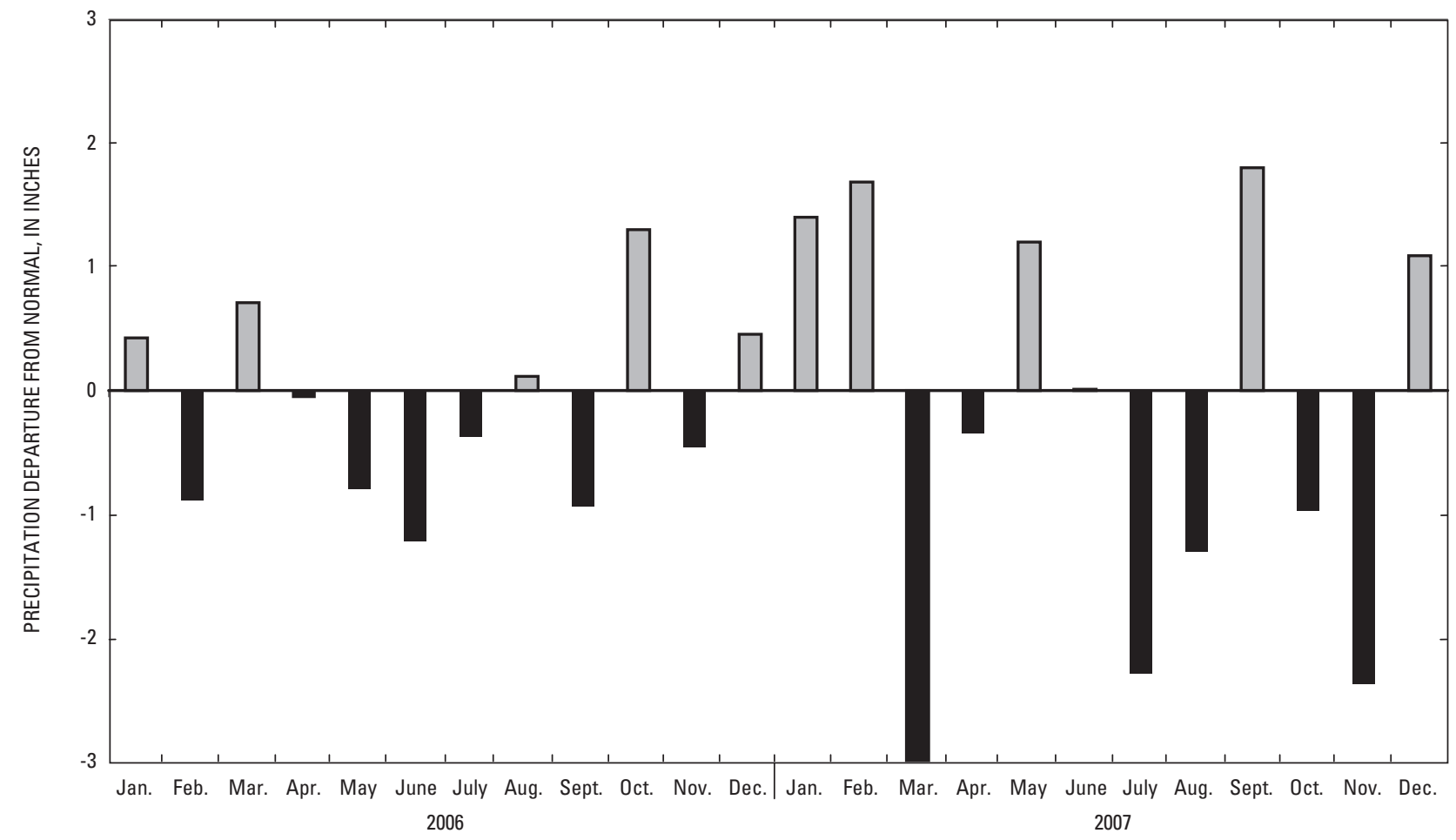

Figure 6. Departure from average monthly precipitation, January 2006 through December 2007. 


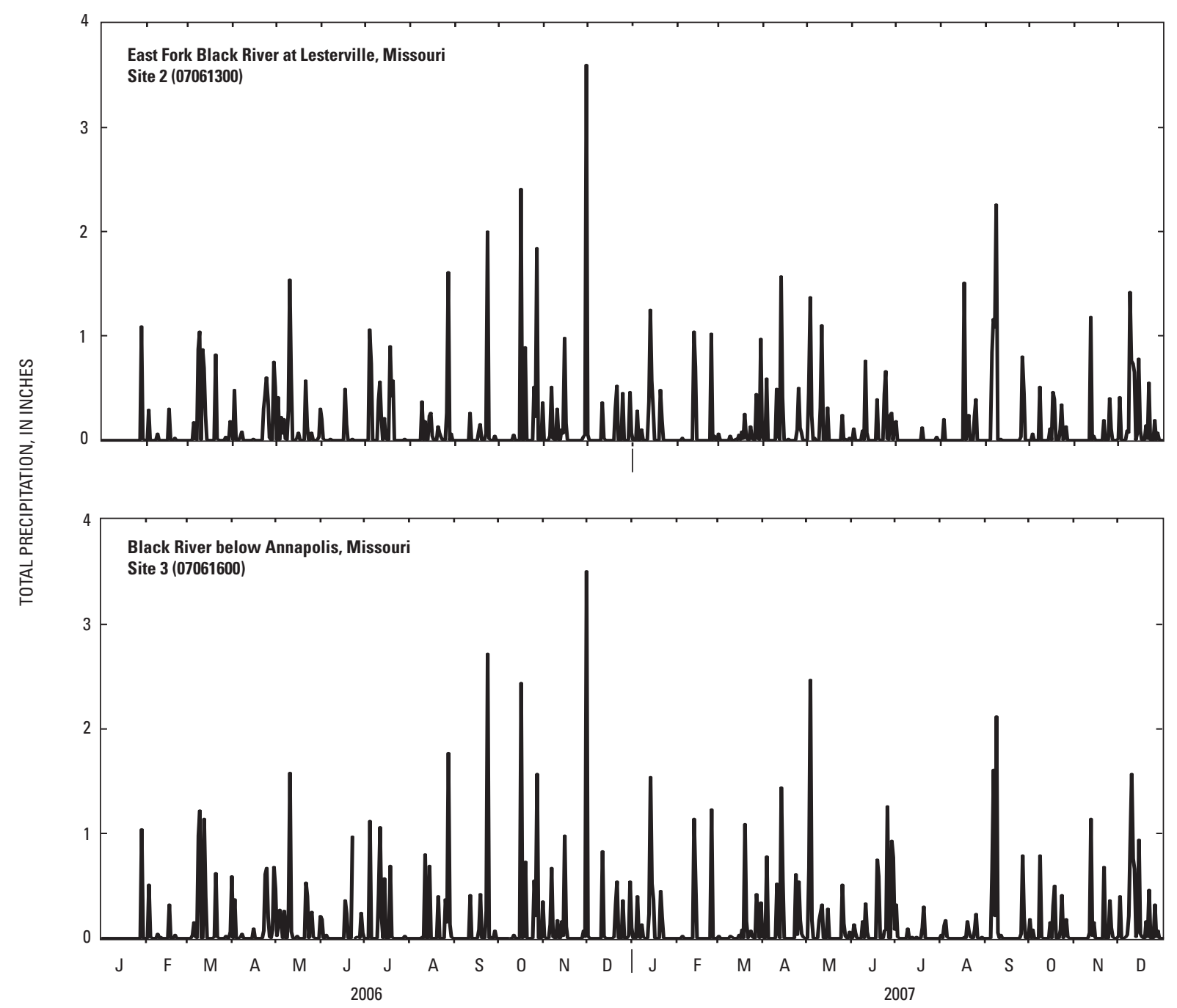

Figure 7. Daily precipitation recorded at two U.S. Geological Survey streamflow-gaging stations, January 2006 through December 2007.

Five surface-water quality samples were collected at the site from June 1963 through June 1964. The constituents sampled included $\mathrm{pH}$, specific conductance, major ions, total dissolved solids (TDS), whole-water alkalinity (acid-neutralizing capacity), dissolved nitrate, total iron, and dissolved manganese. The maximum recorded water-surface elevation of $667.68 \mathrm{ft}$ occurred on November 19, 1985. The mean annual streamflow for the period of record is $120 \mathrm{ft}^{3} / \mathrm{s}$ (U.S. Geological Survey, 2007).

Construction also occurred at the lower Taum Sauk reservoir during the study period. Because the lower reservoir captured much of the sediments transported during the upper reservoir embankment breach, the lower reservoir became very turbid with suspended particles. An alum-based flocculent was added to the lower reservoir by Ameren UE to aid in the settling of the finer clay particles. The flocculent removed the electrostatic charge of the particles, which caused the particles to group together and once large enough, fall from suspension. The alum-based flocculent used to reduce turbidity in the lower reservoir primarily is used for drinking-water treatment
(Federal Energy Regulatory Commission, 2006), and was composed of aluminum sulfate $\left(\mathrm{Al}_{2} \mathrm{O}_{12} \mathrm{~S}_{3}\right)$. During the flocculation period, excess water was released from the lower reservoir to reduce the water level to the normal pool elevation, which resulted in the release of some flocculent into the East Fork Black River. Removal of the settled sediments from the bottom of the lower reservoir by dredging also occurred during the study period. Much of the water in the lower reservoir was released into the East Fork Black River before dredging began. Water was released through the sluice rather than over the spillway prior to dredging. After dredging, limited releases of water took place in order to restore the lower reservoir back to its normal pool.

The lower part of the study area is located on the main stem of the Black River. A gaging station was installed along State Highway K (USGS identifier 07061600; fig. 1) downstream from Annapolis on the main stem of the Black River, downstream from the junction with the East, Middle, and West Forks Black River, and upstream from Clearwater Lake (fig 1). The mean annual streamflow for the period of record (January 
2006 to September 2007) is $639 \mathrm{ft}^{3} / \mathrm{s}$ (U.S. Geological Survey, 2007). The USGS has been collecting water-quality data bimonthly at the State Highway K sampling site as part of the Missouri ambient stream water-quality monitoring program since November 1999 (U.S. Geological Survey, 1999). Water-quality data were first collected at this site as part of the National Water-Quality Assessment (NAWQA) program, Ozark Plateaus study unit from May 1993 through September 1995 (Davis and others, 1995). This sampling site was used in the current study because of its historical dataset and to observe the effects of the East Fork Black River on the main stem of the Black River after it joined the West and Middle Forks.

Continuous water-quality monitors (CWQM) were installed at each gaging station to measure physical properties (specific conductance, $\mathrm{pH}$, water temperature, dissolved oxygen, and turbidity). The CWQM measured the physical properties every 15 minutes and transmitted the data every hour by satellite telemetry to the USGS National Water Information System (NWIS) database. Each water-quality sampling site also was equipped with an automatic pumping sampler to collect daily suspended-sediment samples. Surface-water quality samples were collected monthly at each site during the first year of the study. Storm event water-quality samples also were collected at each site. During the second year, the frequency of sampling decreased to bimonthly. Constituents analyzed included the physical properties listed above, indicator bacteria [fecal coliform and Escherichia coli (E. coli)], chemical oxygen demand (COD), nutrients such as nitrogen and phosphorous, major ions such as calcium and magnesium, and select trace metals such as aluminum, iron, and lead. Streambed-sediment samples also were collected four times during the first year of the study. These samples were sieved for size analyses and the fine-grained fractions less than 0.063 millimeters $(\mathrm{mm})$ were analyzed for major ions and trace metals by inductively coupled argon plasma-mass spectrometry (ICP-MS).

\section{Sample Collection and Analysis Methods}

Data for this study were collected by many different techniques described further in the following sections. Surfacewater and suspended-sediment samples were collected to evaluate changes in the water quality during the study period. Streambed sediments were collected to evaluate the chemical composition and transport of sediments during and after the embankment breach. In addition, CWQMs were placed at each sampling site to measure physical properties in realtime.

Hereinafter, the three sampling sites will be referred to in their downstream order, therefore, East Fork Black River near Lesterville (07061270) will be referred to as site 1, East Fork Black River at Lesterville (07061300) as site 2, and Black River below Annapolis (07061600) as site 3 (fig. 1).

\section{Surface-Water Quality}

Discrete surface-water quality sampling was performed monthly during 2006 and bimonthly during 2007. Storm event sampling also was performed during 2006. Field properties were measured and indicator bacteria samples were collected and analyzed by standard USGS methods as described in Wilde (variously dated). Water-quality samples also were collected according to standard USGS sample collection and processing protocols described by Wilde and others (2004). All chemical analyses were performed by the USGS National Water Quality Laboratory (NWQL) in Lakewood, Colorado, according to established procedures (table 1).

Water-quality samples were collected by the equal-width increments (EWI) method. This method is used to collect samples representative of the entire stream width in a fixed location because the streams have relatively uniform depth and streamflow velocities (U.S. Geological Survey, 2006a). The water samples consisted of approximately 10 subsamples collected within the designated cross section. During low- to medium-flow conditions, samples were collected with a handheld DH-81 isokinetic sampler (fig. 8). During high flows, such as during storm events when wading was not possible, samples were collected from the bridge by the EWI method using either a D-95 sampler or a D-96 collapsible bag sampler (U.S. Geological Survey, 2006a). All subsamples were composited in a polypropylene churn before processing.

Dissolved oxygen, specific conductance, and water temperature were measured in-situ at three equally spaced sections in the stream to acquire a median value representative of the sampling cross section. An additional specific conductance measurement was performed on an aliquot from the churn to account for any degradation that may have occurred after collection. Measurements of $\mathrm{pH}$ and acid-neutralizing capacity (ANC) also were performed on aliquots from the churn. Indicator bacteria samples were collected in a separate 500 -milliliter $(\mathrm{mL})$ polypropylene bottle at the centroid of the stream and chilled until processed by the membrane filtration method described in Myers and others (2007). All constituents listed in table 1 were extracted from the churn, processed, and prepared for shipment to the NWQL for chemical analysis. Water-quality results were published in the USGS annual water data reports for 2006 and 2007 (U.S. Geological Survey, 2006b, 2007) and also are available in table 2 (at the back of the report).

Both suspended-sediment concentrations (SSC) and total suspended solids (TSS) concentrations were collected during the study period and are mentioned in this report extensively. However, there is a difference between these constituents and may not be considered comparable because of collection and analytical differences. SSC data are calculated by measuring the dry weight of all sediment from a known volume of a water and sediment sample. A TSS analysis is performed by measuring the dry weight of sediment from a known volume of a subsample of a composited sample (Gray and others, 2000). Organic particles are removed from suspended- 
Table 1. Analytical methods and method reporting levels used by the U.S. Geological Survey National Water Quality Laboratory.

[NTRU, nephelometric turbidity ratio unit; ICP, inductively coupled argon plasma; mg/L, milligram per liter; AES, atomic emission spectroscopy; IC, ion chromatography; ASF, automated-segmented flow; N, nitrogen; P, phosphorous; MS, mass spectrometry; $\mu \mathrm{g} / \mathrm{L}$, microgram per liter; AF, atomic fluorescence]

\begin{tabular}{|c|c|c|c|}
\hline Analyte & Analytical method & $\begin{array}{l}\text { Method } \\
\text { number }\end{array}$ & $\begin{array}{c}\text { Method reporting } \\
\text { level }\end{array}$ \\
\hline Turbidity & Broad band light $\mathrm{t}^{\mathrm{a}}$ & 2130 & 2 NTRU \\
\hline Calcium, dissolved & $\mathrm{ICP}^{\mathrm{b}}$ & I-147287 & $0.04 \mathrm{mg} / \mathrm{L}$ \\
\hline Magnesium, dissolved & ICP-AES & I-147287 & $.008 \mathrm{mg} / \mathrm{L}$ \\
\hline Potassium, dissolved & ICP-AES ${ }^{\mathrm{a}}$ & 3210-ICP & $.16 \mathrm{mg} / \mathrm{L}$ \\
\hline Sodium, dissolved & ICP-AES ${ }^{b}$ & I-147287 & $.1 \mathrm{mg} / \mathrm{L}$ \\
\hline Chloride, dissolved & $\mathrm{IC}^{\mathrm{c}}$ & I-205785 & $.2 \mathrm{mg} / \mathrm{L}$ \\
\hline Fluoride, dissolved & ASF Ion-selective Electrode ${ }^{c}$ & I-232789 & $.1 \mathrm{mg} / \mathrm{L}$ \\
\hline Sulfate, dissolved & $\mathrm{IC}^{\mathrm{c}}$ & I-205785 & $.18 \mathrm{mg} / \mathrm{L}$ \\
\hline Residue, total suspended solids (TSS) & Gravimetric $^{c}$ & I-376589 & $10 \mathrm{mg} / \mathrm{L}$ \\
\hline Residue, total dissolved solids (TDS) & Gravimetric $^{c}$ & I-175089 & $10 \mathrm{mg} / \mathrm{L}$ \\
\hline Ammonia + organic nitrogen, total as $\mathrm{N}$ & Colorimetry, ASF, Microkjeldahl $^{\mathrm{d}}$ & I-451591 & $.1 \mathrm{mg} / \mathrm{L}$ \\
\hline Ammonia, dissolved as $\mathrm{N}$ & Colorimetry ${ }^{\mathrm{b}}$ & I-252290 & $.04 \mathrm{mg} / \mathrm{L}$ \\
\hline Nitrate + nitrite, dissolved as $\mathrm{N}$ & Colorimetry, $\mathrm{ASF}^{\mathrm{b}}$ & $\mathrm{I}-254590$ & $.06 \mathrm{mg} / \mathrm{L}$ \\
\hline Nitrite, dissolved as $\mathrm{N}$ & Colorimetry $^{\mathrm{b}}$ & $\mathrm{I}-254090$ & $.008 \mathrm{mg} / \mathrm{L}$ \\
\hline Orthophosphate, dissolved as $\mathrm{P}$ & Colorimetry $^{\mathrm{b}}$ & I-269190 & $.018 \mathrm{mg} / \mathrm{L}$ \\
\hline Phosphorous, dissolved as P & Colorimetry, ASF, Microkjeldahl $^{\mathrm{d}}$ & I-261099 & $.04 \mathrm{mg} / \mathrm{L}$ \\
\hline Phosphorous, total as $\mathrm{P}$ & Colorimetry, ASF, Microkjeldahl $^{\mathrm{d}}$ & I-261099 & $.04 \mathrm{mg} / \mathrm{L}$ \\
\hline Chemical Oxygen Demand (COD) & Colorimetry $^{\mathrm{c}}$ & I-356189 & $10 \mathrm{mg} / \mathrm{L}$ \\
\hline Aluminum, dissolved & ICP-MS & $\mathrm{I}-247792$ & $1.6 \mu \mathrm{g} / \mathrm{L}$ \\
\hline Aluminum, total & $\mathrm{ICP}_{-\mathrm{MS}^{\mathrm{g}}}$ & $\mathrm{I}-447197$ & $2 \mu \mathrm{g} / \mathrm{L}$ \\
\hline Arsenic, dissolved & ${\mathrm{ICP}-M S^{\mathrm{h}}}$ & I-202005 & $.06 \mu \mathrm{g} / \mathrm{L}$ \\
\hline Boron, dissolved & ICP-AES ${ }^{\mathrm{i}}$ & I-147295 & $1.2 \mu \mathrm{g} / \mathrm{L}$ \\
\hline Cadmium, dissolved & ICP-MS & I-447197 & $.04 \mu \mathrm{g} / \mathrm{L}$ \\
\hline Cadmium, total & $\mathrm{ICP}_{-M S^{\mathrm{f}}}$ & I-247792 & $.014 \mu \mathrm{g} / \mathrm{L}$ \\
\hline Copper, dissolved & ICP-MS & I-202005 & $.04 \mu \mathrm{g} / \mathrm{L}$ \\
\hline Iron, dissolved & $\mathrm{ICP}_{\mathrm{AES}}^{\mathrm{b}}$ & I-147287 & $6 \mu \mathrm{g} / \mathrm{L}$ \\
\hline Lead, dissolved & ICP-MS & I-247792 & $.08 \mu \mathrm{g} / \mathrm{L}$ \\
\hline Lead, total & ICP-MSg & I-447197 & $.06 \mu \mathrm{g} / \mathrm{L}$ \\
\hline Lithium, dissolved & ICP-AES $^{\mathrm{b}}$ & I-147287 & $.04 \mu \mathrm{g} / \mathrm{L}$ \\
\hline Manganese, dissolved & ICP-AES ${ }^{b}$ & I-147287 & $.6 \mu \mathrm{g} / \mathrm{L}$ \\
\hline Mercury, total & AF, Cold Vapor ${ }^{\mathrm{h}}$ & I-446401 & $.01 \mu \mathrm{g} / \mathrm{L}$ \\
\hline Selenium, dissolved & $\mathrm{ICP}_{-\mathrm{MS}^{\mathrm{h}}}$ & I-202005 & $.04 \mu \mathrm{g} / \mathrm{L}$ \\
\hline Strontium, dissolved & ICP-AES & I-147287 & $1 \mu \mathrm{g} / \mathrm{L}$ \\
\hline Zinc, dissolved & ${\mathrm{ICP}-\mathrm{MS}^{\mathrm{h}}}$ & I-202005 & $.6 \mu \mathrm{g} / \mathrm{L}$ \\
\hline Zinc, total & $\mathrm{ICP}^{-\mathrm{MS}^{\mathrm{h}}}$ & I-402005 & $2 \mu \mathrm{g} / \mathrm{L}$ \\
\hline
\end{tabular}

${ }^{a}$ American Public Health Association and others, 1998.

${ }^{\mathrm{b} F i s h m a n,} 1993$.

${ }^{\mathrm{c}}$ Fishman and Friedman, 1989.

'Patton and Truitt, 2000.

${ }^{\mathrm{e}}$ Faires, 1993.

${ }^{\mathrm{f}}$ Garabino and Struzeski, 1998.

${ }^{\mathrm{g}}$ Garbarino and others, 2006.

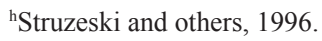

${ }^{\mathrm{i}}$ Garabino and Damrau, 2001. 


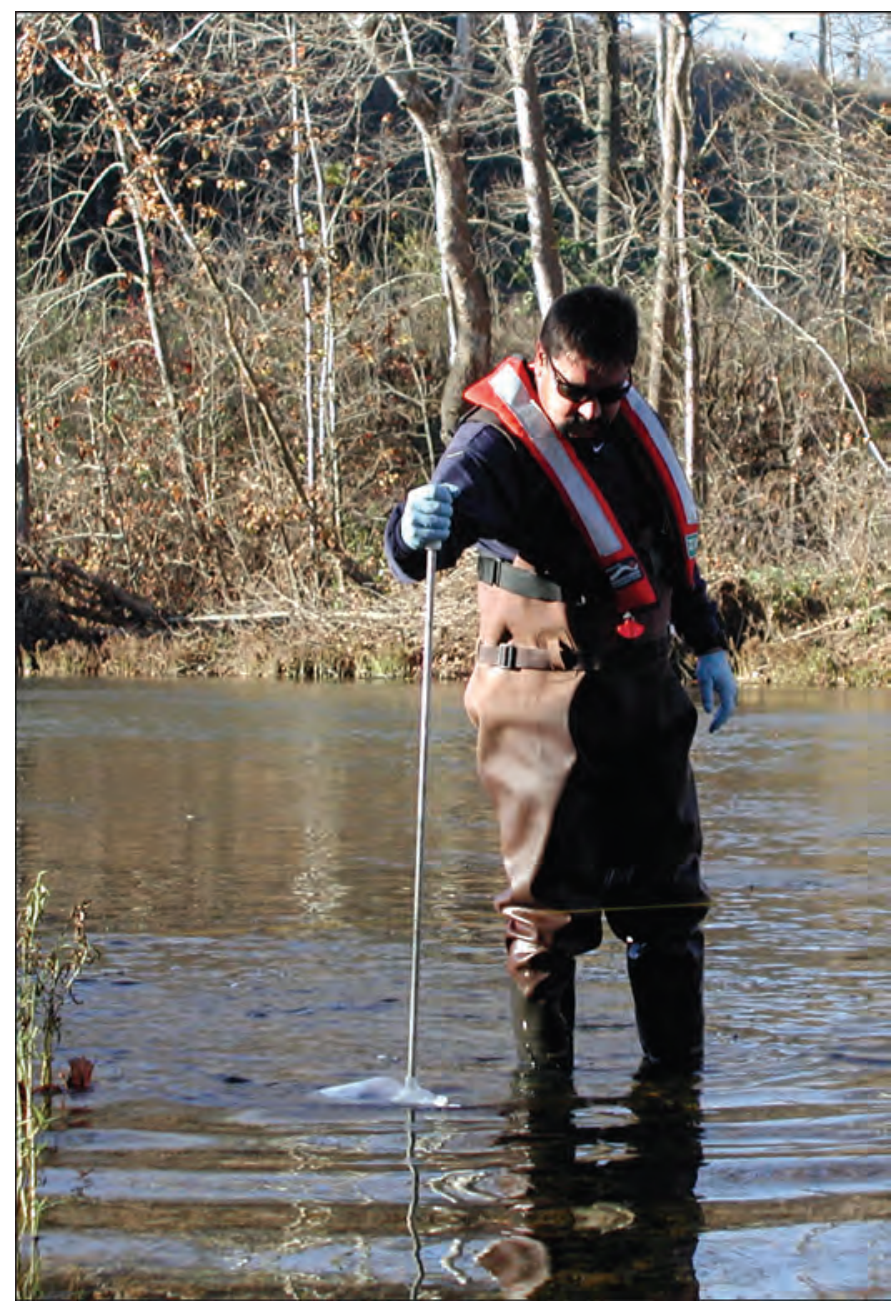

Figure 8. A U.S. Geological Survey hydrographer collecting a discrete surface-water quality sample using the equal-width increment (EWI) method.

sediment samples prior to analysis, while suspended-solids concentrations can include organics. SSC are considered the most accurate measurement of the actual stream-sediment concentrations because of the representative sampling and analytical techniques used (Davis and others, 1995). Although SSC is more accurate, TSS concentrations also were collected during this study because the State standards for Missouri are based on suspended-solids concentrations.

\section{Suspended and Streambed Sediment}

Suspended-sediment samples also were collected during monthly and bimonthly water-quality sampling. Collection techniques were designed to obtain a cross-sectional representation of the SSC using standard USGS protocols as described in Edwards and Glysson (1999). During wadeable stream conditions, suspended-sediment samples were collected by the EWI method at approximately 10 subsections in the cross section using a DH-48 sediment sampler. Suspended-sediment samples also were collected on the rise, peak, and fall of storm events to define the SSC to streamflow relation. Storm event samples typically were collected from the bridge by EWI method using either a D-74 or D-95 sampler.

Daily suspended-sediment samples also were collected at each site during the study using a programmable automatic sampler (fig. 9). In an effort to determine the large sediment fluxes that occurred as a result of the reservoir embankment breach, automatic samplers were programmed to collect a single sample twice daily during the first 3 months of the study. After the 3-month period, the automatic samplers were programmed to collect one sample per day. Twenty-four samples could be stored in the automatic sampler, which were removed from the sampler during CWQM calibration visits. All cross-section suspended-sediment samples and daily suspended-sediment samples were analyzed by the Missouri Water Science Center Sediment Laboratory in Rolla, Missouri, using standard USGS procedures as described in Guy (1969). Mean daily suspended-sediment discharges and concentrations were published in the USGS annual water data reports for 2006 and 2007 (U.S. Geological Survey, 2006b, 2007).

Streambed-sediment samples were collected during the first year to analyze sediment-size distribution and trace metal content. Monthly streambed-sediment samples were collected from May through August 2006. Samples were collected from approximately 10 to 20 subsamples in the wadeable stream reach surrounding the cross-section location using a sterile Nalgene cup. The subsamples were composited into one large plastic zip-lock bag and shipped to the USGS Mineral Resource Laboratory in Lakewood, Colorado, for size and chemical analysis of trace metals by ICP-MS.

\section{Continuous Water Quality}

The CWQM's were placed at all three sampling sites to measure field properties and supply the public with real-time stream conditions by the internet. The CWQM's were cleaned and calibrated following USGS standard methods and procedures as described in Wagner and others (2006). Sites were visited approximately every 2 weeks to maintain calibrations

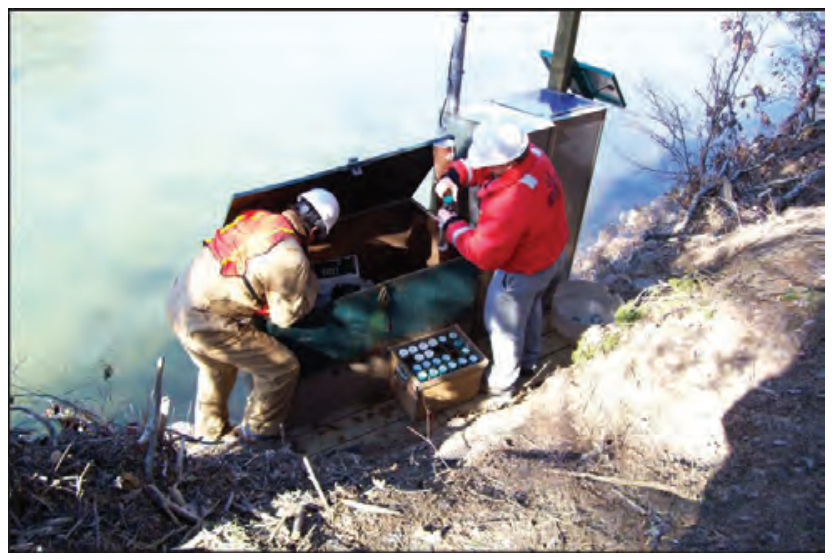

Figure 9. U.S. Geological Survey hydrographers collecting daily suspended-sediment samples from automatic sampler. 
and service equipment. Fouling and drift corrections were applied to the recorded data based on standard criteria as noted in table 3. These field calibration data are on file at the USGS Missouri Water Science Center in Rolla, Missouri.

Each CWQM sensor measures a different property: specific conductance, $\mathrm{pH}$, water temperature, dissolved oxygen, and turbidity (fig. 10). The sensors also have individual ranges of operation, but none were exceeded during the study. The CWQM's were deployed at each site through a 4-inch PVC pipe near the gaging station orifice line to protect from damage and to keep the monitor in a fixed location during the study period.

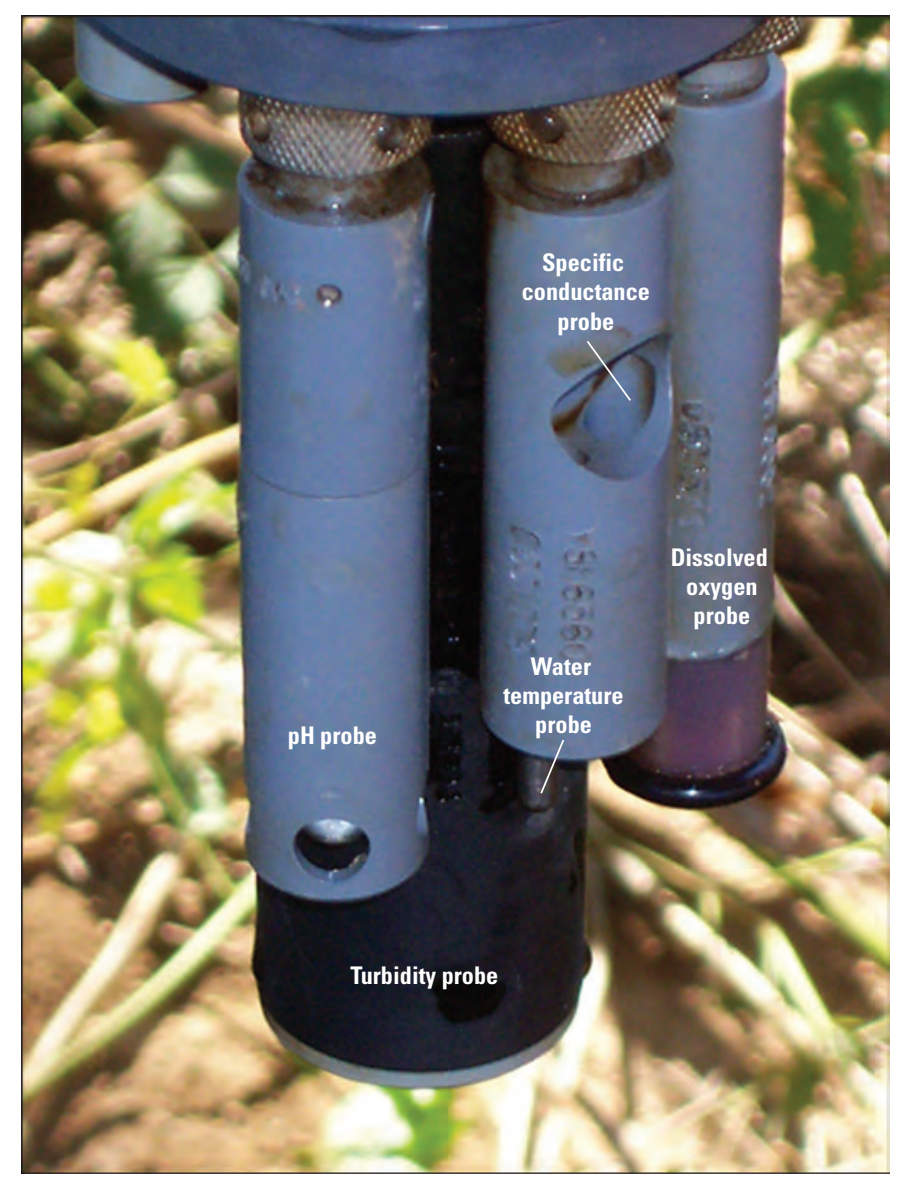

Figure 10. Water-quality monitor used to measure field properties.

The CWQM data for each property were processed after each site visit. Corrections based on sensor fouling and calibration drift were calculated and applied when necessary to correct data between site visits. If the data exceeded the maximum allowable correction limits as listed in table 3, the data were not published. Other reasons for missing data also included equipment failure, interference with aquatic biota, low flow conditions causing monitors to be out of the water, and ice conditions. Corrections were applied to the data as soon after the site visit as possible to keep accurate data available on the NWISweb. No data were estimated. Missing data or data not published were minimal for all properties, accounting for only 13 percent or less of the total days data were collected from January 2006 to December 2007 at all sites. Publication procedures were followed as described in Wagner and others (2006). Daily mean values for each physical property (median values for $\mathrm{pH}$ ) were published in the USGS annual water data reports for 2006 and 2007 (U.S. Geological Survey, 2006b and 2007).

\section{Quality Assurance and Quality Control}

Surface-water quality-assurance samples were collected at all three sampling sites during the study period. A total of five samples were collected; three replicate samples and two field blank samples. The replicate samples were collected to determine the laboratory precision of the environmental data. Field blank samples were collected to detect any contamination of equipment between sites. All blank constituent concentrations were at or below the reporting level used by each analytical method as listed in table 1. Differences between replicate and environmental sample concentrations were within the laboratory analytical error. Field blank and replicate data were published in the USGS annual water data reports for 2006 and 2007 (U.S. Geological Survey, 2006b and 2007) and also are available in table 2.

Quality control procedures also were applied to the physical properties collected by cross-sectional samples and the CWQM to ensure both datasets were comparable. Table 4 shows cross-section measurements and the CWQM recordings of physical properties collected within the same hour. The relative percent difference (RPD) between cross-section and continuous data also are shown in the table. RPD is a measure of precision for two different collection methods of the same constituent. RPD was calculated as the absolute difference between the cross-section and CWQM data divided by the average of the two values and expressed as a percentage. A RPD of 162 percent is noted for turbidity measurements on January 29, 2006, at site 2. The CWQM became silted inside the deployment pipe on this date during the release of water from the lower reservoir and did not function properly. The CWQM data were rated poor, but were not deleted from the dataset. The SSC for the January 29, 2006, collection have a RPD of only 1 percent, indicating an error only in the turbidity measurements from the CWQM.

The average RPDs for $\mathrm{pH}$, specific conductance, and water temperature were less than 10 percent at all sites, and the median RPDs were also less than 10 percent. Average dissolved oxygen RPDs were 12 percent except site 3, which was 6 percent. The median RPD for dissolved oxygen was 11 percent or less for all three sites. The average and median RPDs for turbidity and SSC varied between sites. The turbidity RPD between cross-section samples and the CWQM readings were not calculated for samples at or below the reporting level because the analytical methods vary between the two datasets. The average turbidity RPD at site 1 (when crosssection measurements were greater than the reporting level) was 88 percent and the median was 27 percent, site 2 had an 


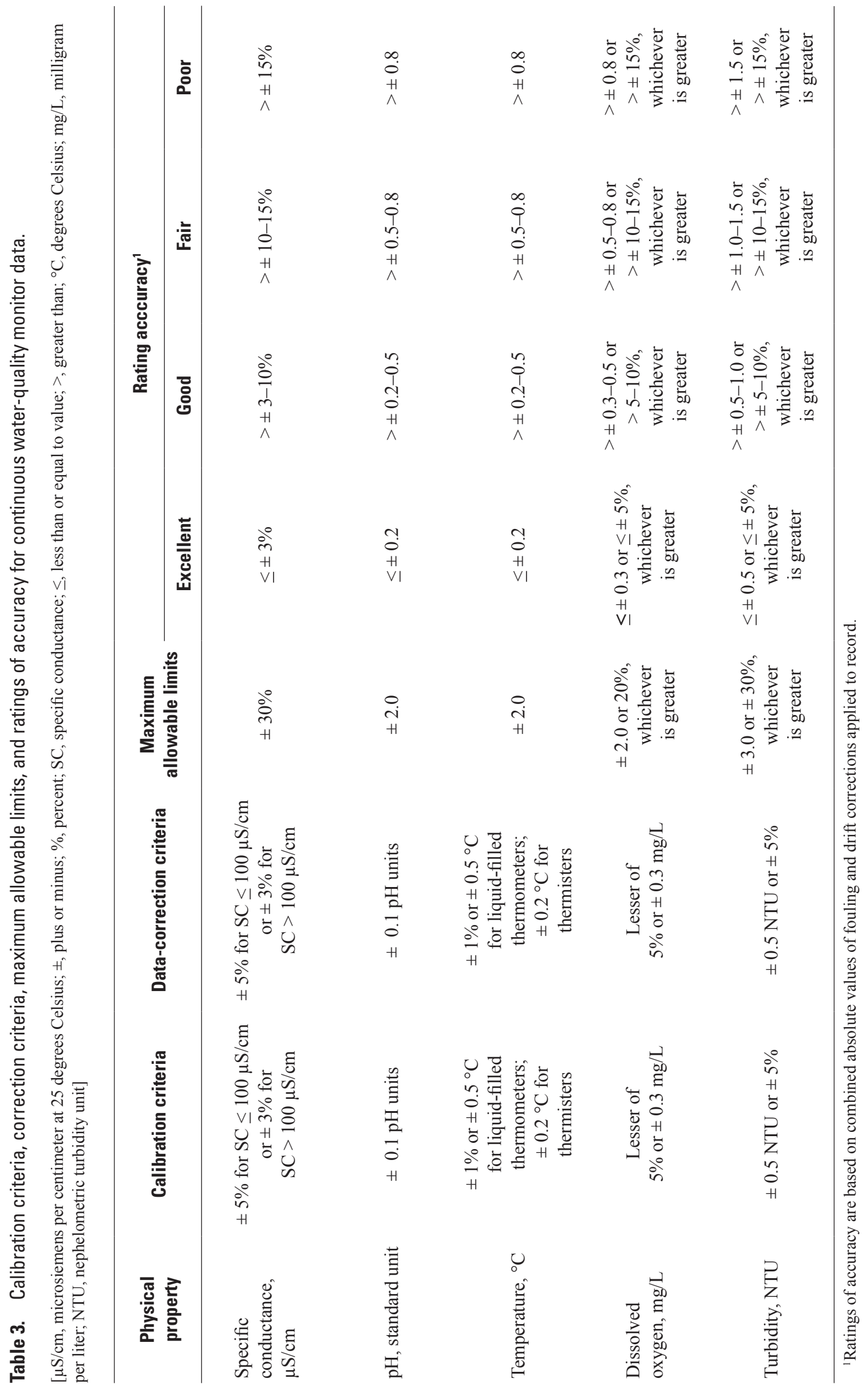




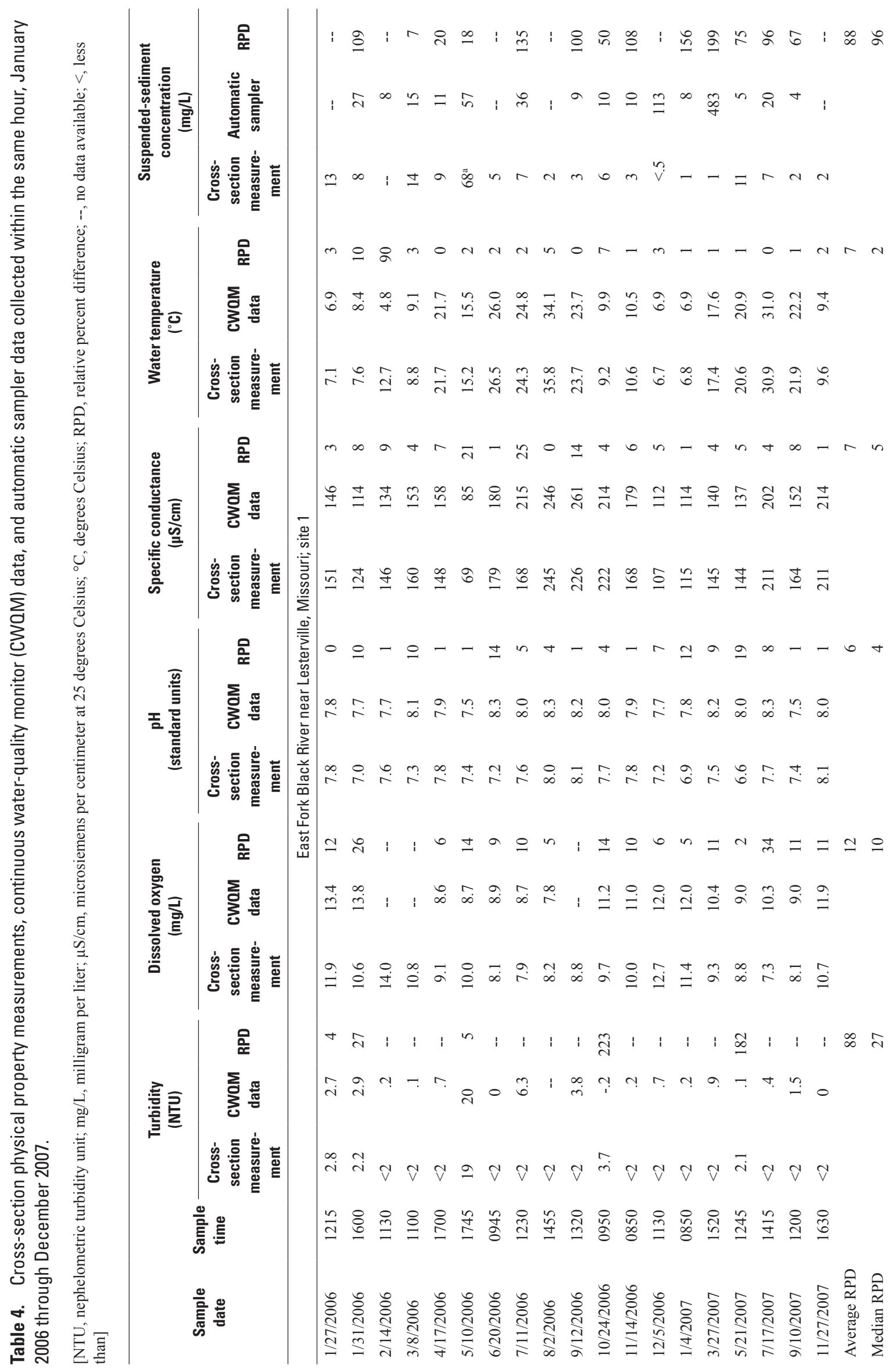




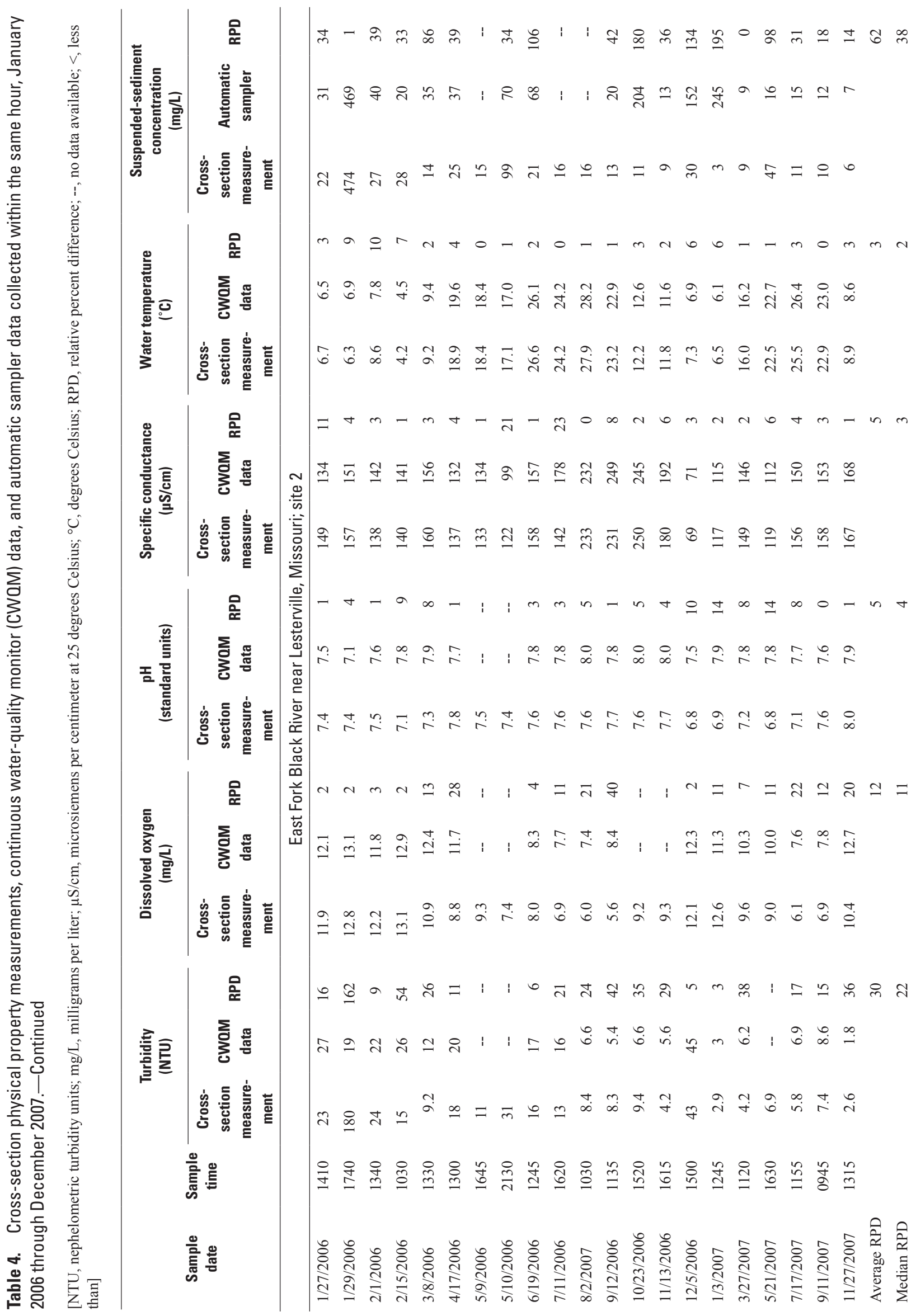




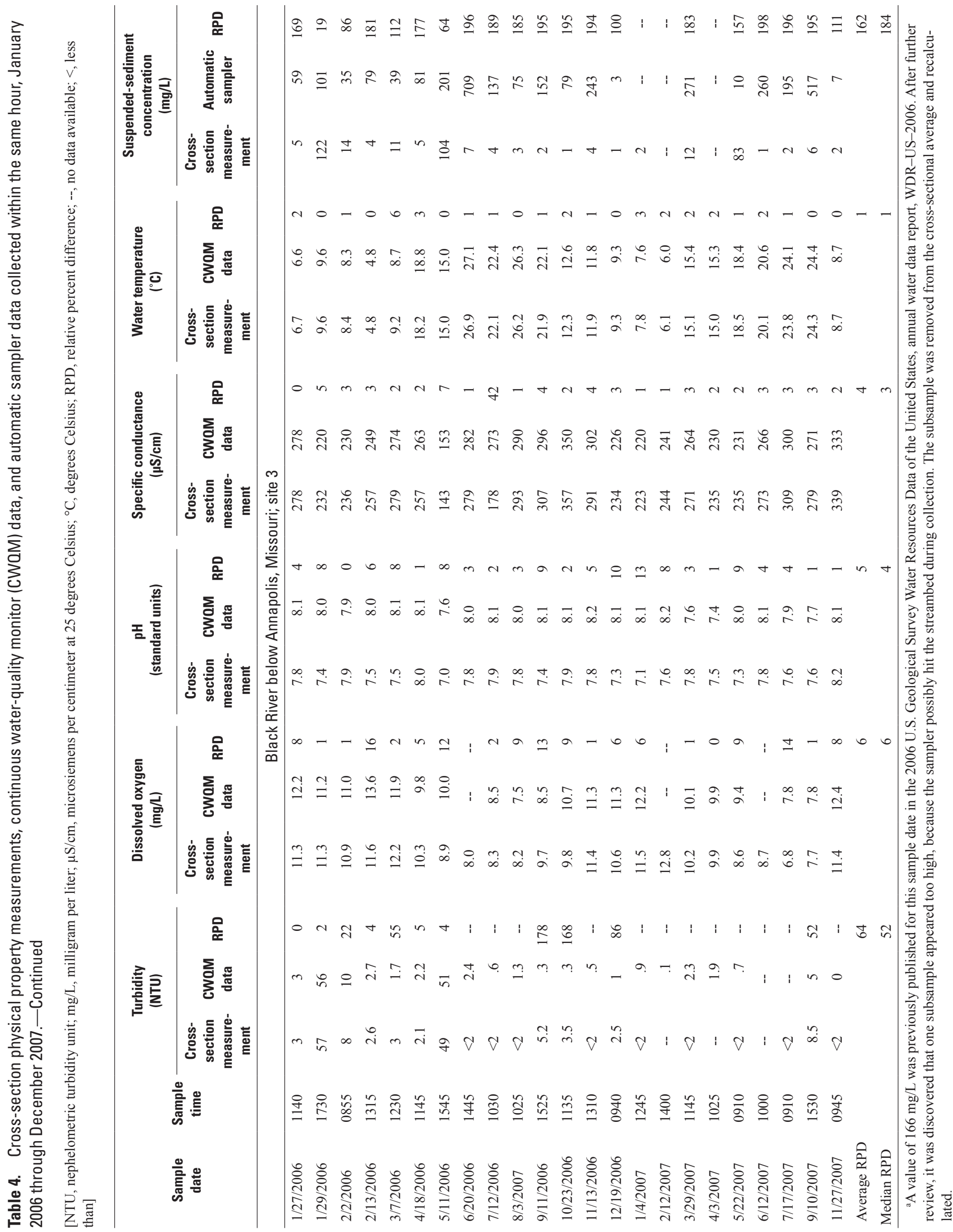


average turbidity RPD of 30 percent and median of 22 percent, and site 3 had an average RPD of 64 percent and median of 52 percent. The average SSC RPD at site 1 was 88 percent and the median RPD was 96 percent. Site 2 had an average RPD of 62 percent and a median RPD of 38 percent for SSC, while site 3 had an average RPD of 162 percent and a median RPD of 184 percent. The large RPDs of the SSC samples could have been caused by the location of the automatic sampler at each site. The automatic samplers were placed on a streambank approximately $1 \mathrm{ft}$ from the edge of water at each site. It is possible that sediments were more concentrated along these streambanks where the stream velocity is typically less than in the centroid of the stream.

Differences between the average and median RPDs for dissolved oxygen, $\mathrm{pH}$, specific conductance, and water temperature were 5 percent or less for all sites. Differences between the average and median turbidity RPDs were 61 percent at site 1,8 percent at site 2 , and 12 percent at site 3 . Differences in average and median RPDs for SSC were 8 percent at site 1,24 percent at site 2 , and 22 percent at site 3 .

Figures 11 through 13 show the physical property measurements for the cross-section samples plotted with the daily mean CWQM data and daily mean streamflow. Most CWQM measurements show a good relation with the corresponding field property. The $\mathrm{pH}$ data from the cross-section samples do not appear to have a good relation with the CWQM data. This is because the cross-section samples represent a single $\mathrm{pH}$ value collected from the churn while the CWQM data are a daily median value.

\section{Data Analysis Methods}

Data collected at each site were analyzed for statistical significance using a variety of methods. Cross-section waterquality samples were tested for correlation between parameters using Kendall's tau. The correlations measure the strength of association between two constituents (Helsel and Hirsch, 1992). A nonparametric test known as the Kruskal-Wallis t-test was performed on all constituents to test for significant differences in distributions. Constituents were determined to be significantly different when the "attained significance level" ( $p$-value) was less than 0.05 . If significant differences were noted, the Tukey's multiple comparison test was performed on the rank-transformed data to identify similarities between the three sites (Helsel and Hirsch, 1992). A two-way analysis of variance test (ANOVA) also was performed on the rank-transformed data of selected parameters to determine the relation between sites as well as seasonal differences.

Boxplots are used to graphically display the distribution of a selected constituent at multiple sites (Helsel and Hirsch, 1992). Boxplots provide a visual summary of the $25^{\text {th }}, 50^{\text {th }}$, and $75^{\text {th }}$ percentiles and any extreme values in the distribution (fig. 14). The boxplots consists of the median value $\left(50^{\text {th }}\right.$ percentile $)$ plotted as a horizontal line, and a box is drawn from the $25^{\text {th }}$ percentile to the $75^{\text {th }}$ percentile. The box length, also known as the interquartile range (IQR), represents one-half of the data values. The IQR is insensitive to the presence of extreme values in the distribution. If a median value does not divide the box into two equal parts, it indicates asymmetry in the data distribution. Adjacent values are located outside the box and, if within 1.5 times the IQR, are shown as whisker lines. The length of the whisker connected to the $75^{\text {th }}$ percentile represents the value of the largest adjacent point; the length of the whisker connected to the $25^{\text {th }}$ percentile represents the smallest adjacent value. Values which are more extreme in either direction than the adjacent values are plotted individually. The values equal to 1.5 to 3.0 times the IQR are called "farout values" and are represented by an ' $x$ ' (D.R. Helsel, U.S. Geological Survey, written comm., 1989). Values greater than the "far-out values" are represented by a circle. If the median data equals the $25^{\text {th }}$ percentile, no center line is shown. If the median of the data equals both the $25^{\text {th }}$ and $75^{\text {th }}$ percentiles, the box will be plotted as a single line. Any boxplots made with censored data (data reported as less than a given value) were modified by making the lower limit of the box equal to the reported value.

All SSC determined by daily sediment samples were used to calculate the suspended-sediment discharge in tons per day (tons/d) using the USGS Graphical Constituent Loading Analysis System (GCLAS) following methods described in Porterfield (1972) and Koltun and others (2006). Daily mean SSC and daily suspended-sediment discharges were published in the USGS annual water data report (U.S. Geological Survey, 2006b, 2007). SSC for missing days were estimated when applicable by using a transport curve to best-fit estimated data. The SSC determined from cross-section suspended-sediment samples were used to calibrate the SSC of the daily samples by applying a coefficient. A coefficient is the ratio of the crosssection SSC to the daily SSC. Coefficients were applied by time between cross-section collections and also were adjusted by the streamflow. During 2006, coefficients ranged from 0.1 to 1.09 at site $1,0.07$ to 1.38 at site 2 , and 0.01 to 1.08 at site 3. Coefficients applied to daily samples during 2007 ranged from 0.12 to 3 at site $1,0.13$ to 2.94 at site 2 , and 0.01 to 0.33 at site 3 .

\section{Assessment of Surface-Water Quality Effects}

Statistical analyses were performed on the data obtained from water-quality sampling, suspended-sediment samples, and CWQMs. This section describes results of statistical tests applied to historical and current data used to identify trends in surface-water quality data from before and after the upper reservoir embankment breach. Statistical summaries also were computed for the CWQM data from each site. 

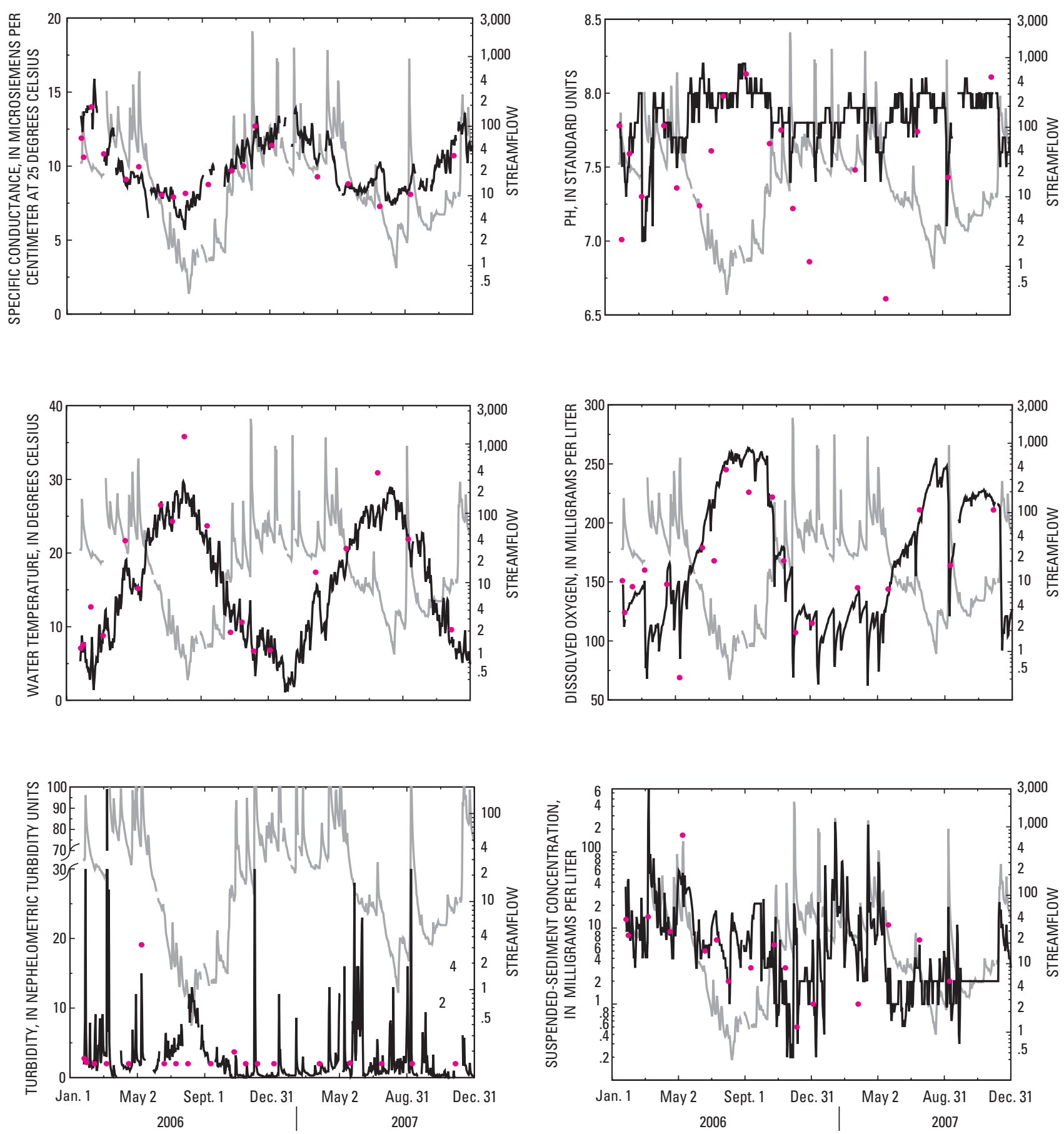

EXPLANATION

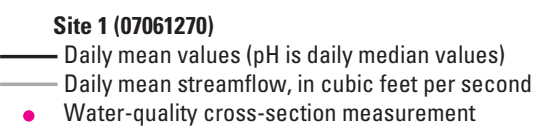

Figure 11. Comparison of continuous data, cross-section measurements, and streamflow from East Fork Black River near Lesterville, Missouri, January 2006 through December 2007. 

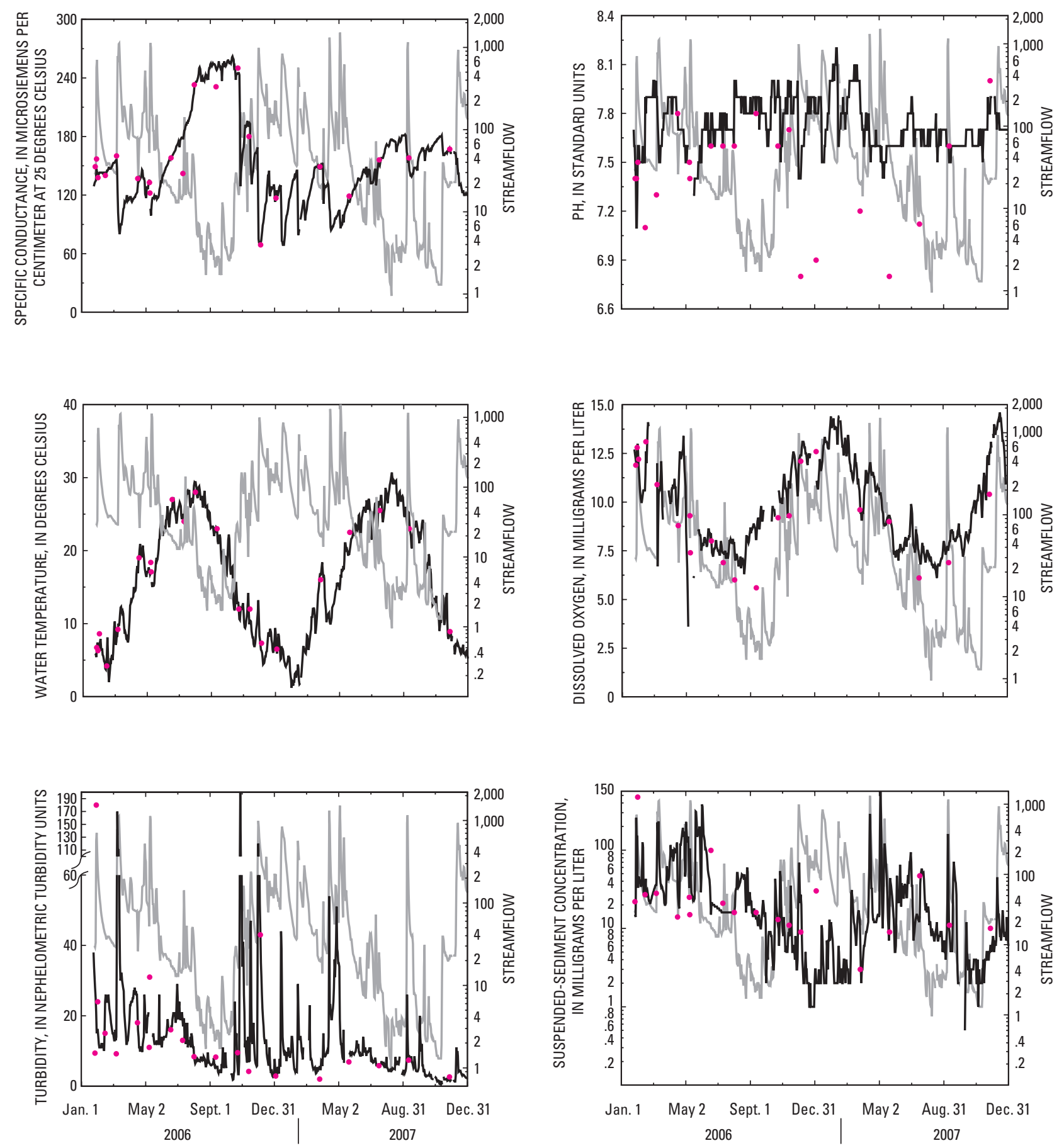

\section{EXPLANATION}

Site 2 (07061300)

- Daily mean values ( $\mathrm{pH}$ is daily median values)

_ Daily mean streamflow, in cubic feet per second

- Water-quality cross-section measurement

Figure 12. Comparison of continuous data, cross-section measurements, and streamflow from East Fork Black River at Lesterville, Missouri, January 2006 through December 2007. 

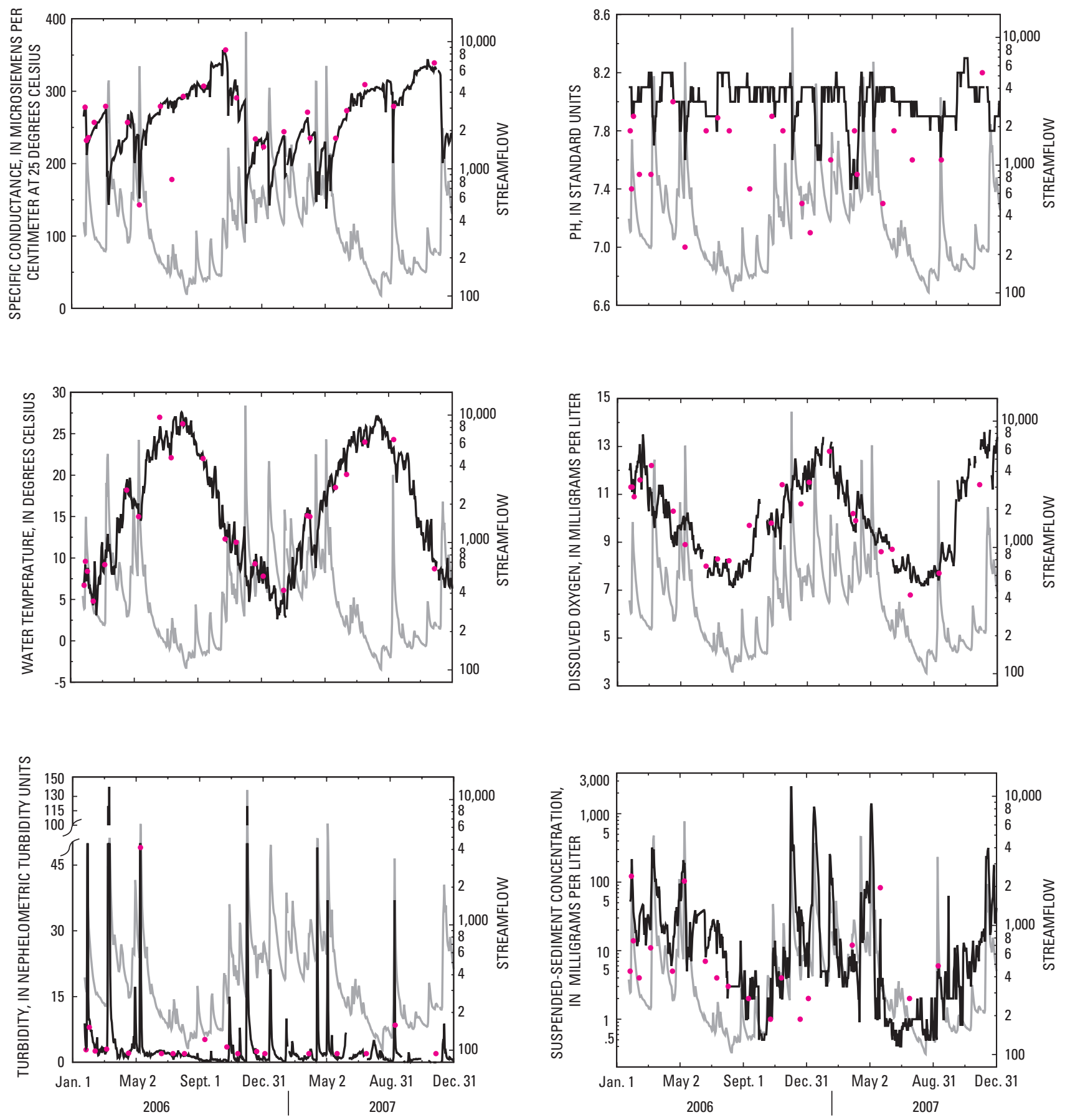

EXPLANATION

Site 3 (07061600)

- Continuous daily mean values ( $\mathrm{pH}$ is daily median values)

- Daily mean streamflow, in cubic feet per second

- Water-quality cross-section measurement

Figure 13. Comparison of continuous data, cross-section measurements, and streamflow from Black River below Annapolis, Missouri, January 2006 through December 2007. 


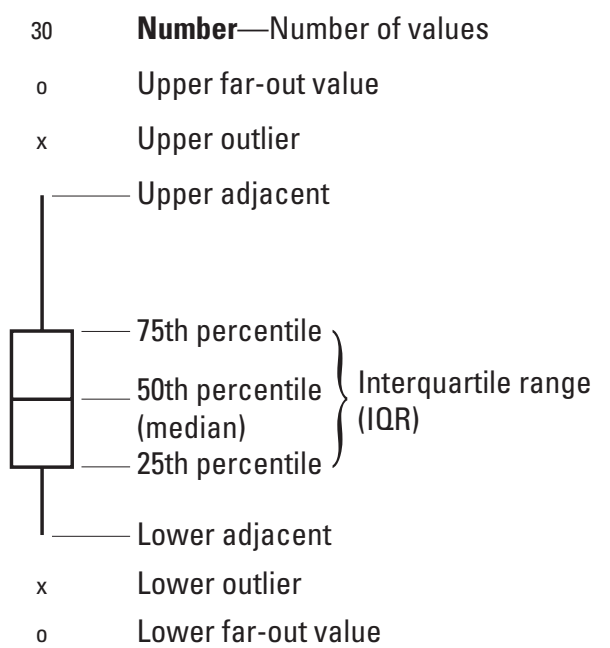

Figure 14. Example of a boxplot.

\section{Surface-Water Quality}

Summary statistics for selected water-quality constituents are found in table 5. The non-parametric Kruskal-Wallis t-test indicated that several constituents were significantly different between sites ( $\mathrm{p}$-value $<0.05$ ). To better define these differences, the multiple comparison Tukey test was performed.

Streamflow and turbidity were significantly different at each of the three sites (p-value $<0.05$; fig. 15). These findings were expected because all three sites have different streambed characteristics and upstream influences such as land use, drainage area, and the lower reservoir for sites 2 and 3 . There were no significant differences between sites 1 and 3 and between sites 2 and 3 for TSS and SSC. However, the TSS and SSC were statistically different between sites 1 and 2 . The differences in TSS and SSC between sites 1 and 2 could be caused by the presence of the lower reservoir between the two sites. Because the lower reservoir was drained to remove sediments captured from the upper reservoir embankment breach during the early months of the study, a large amount of suspended sediments likely was introduced into the East Fork Black River. Additionally, dredging of sediment that had settled out during the flocculation process also may have influenced concentration values during the first year. It is likely that site 3 also would have been influenced by the release of suspended solids from the lower reservoir, though the data would not have equivalent concentrations as site 2 because of the larger drainage area for site 3. Historical TSS and SSC data available for site 3 also were compared to data collected during 2006-07 at site 1. It was determined that data from both datasets were statistically similar $(\mathrm{SSC}$ p-value $=0.51$, TSS p-value $=0.40$ ).

Cross-section water-quality data from sites 1 and 2 were similar in hardness, sulfate, total dissolved solids, and nitrate plus nitrite concentrations. The similarities in the dissolved constituents seem reasonable because sites 1 and 2 are along the same stream reach, and these constituents would not be expected to change as rapidly as suspended solids. Site 3 has additional influences of dissolved constituents from the West and Middle Fork Black Rivers.

In addition to determining similarities between sites, seasonal trends also were investigated. The seasons were defined as four 3-month periods for winter, spring, summer, and fall. Winter months were December through February, spring months were March through May, summer months were June through August, and the fall months were September through November. A two-way ANOVA test was used to identify differences between sites and seasons simultaneously on the ranked data. Few constituents showed statistically similar seasonal trends for all sites. However, a significant seasonal decrease from winter to fall was observed for turbidity and dissolved and total recoverable aluminum at sites 1 and 2 . The decrease in turbidity and dissolved and total recoverable aluminum, especially at site 2 , could be attributed to the alum flocculent used to reduce turbidity from suspended sediments in the lower reservoir during January 2006. The alum flocculent was made of aluminum sulfate, and as the flocculent was removed from the lower reservoir and diluted in the East Fork Black River, the concentrations of aluminum and sulfate would also be expected to decrease. Another possible source of the larger concentrations during the study period could be the upper reservoir embankment breach itself. Because aluminum occurs as aluminosilicate clay minerals in the soils of the study area, the embankment breach would have released aluminum to the East Fork Black River, which over time would have moved through the study area. A seasonal decrease from winter to fall in suspended sediments was observed for site 2, while an increase was observed for site 1 (fig. 16). The increase in SSC at site 1 is thought to be caused by the river reconstruction that took place during the spring and summer months. The river reconstruction involved the removal and stabilization of streambank material. Heavy equipment also was observed crossing the East Fork Black River just downstream from site 1 during base-flow conditions. The reconstruction efforts caused backflow and the deposition of point bars, affecting the water quality at site 1 during the summer and fall months of the study.

Linear correlation analyses were performed on several constituents at each site using Kendall's tau. The correlation measures the strength of association between two constituents (Helsel and Hirsch, 1992). All sites had coefficients $\left(\mathrm{R}^{2}\right)$ greater than 0.70 between dissolved oxygen and water temperature, specific conductance and water hardness, specific conductance and TDS, and turbidity and SSC, indicating good correlation. Correlations between turbidity and TSS and TSS and SSC had large coefficients $\left(\mathrm{R}^{2}>0.70\right)$ indicating strong correlation, but because of a limited data set and numerous TSS concentrations at the detection limit, the correlation coefficients could be skewed. Data collected at site 1 had larger correlation coefficients $\left(\mathrm{R}^{2}=0.80\right.$ to 0.99$)$ than the data collected at the other two sites. Site 3, the most downstream site and largest drainage area, had the smallest correlation coefficients $\left(\mathrm{R}^{2}=0.70\right.$ to 0.98$)$. 


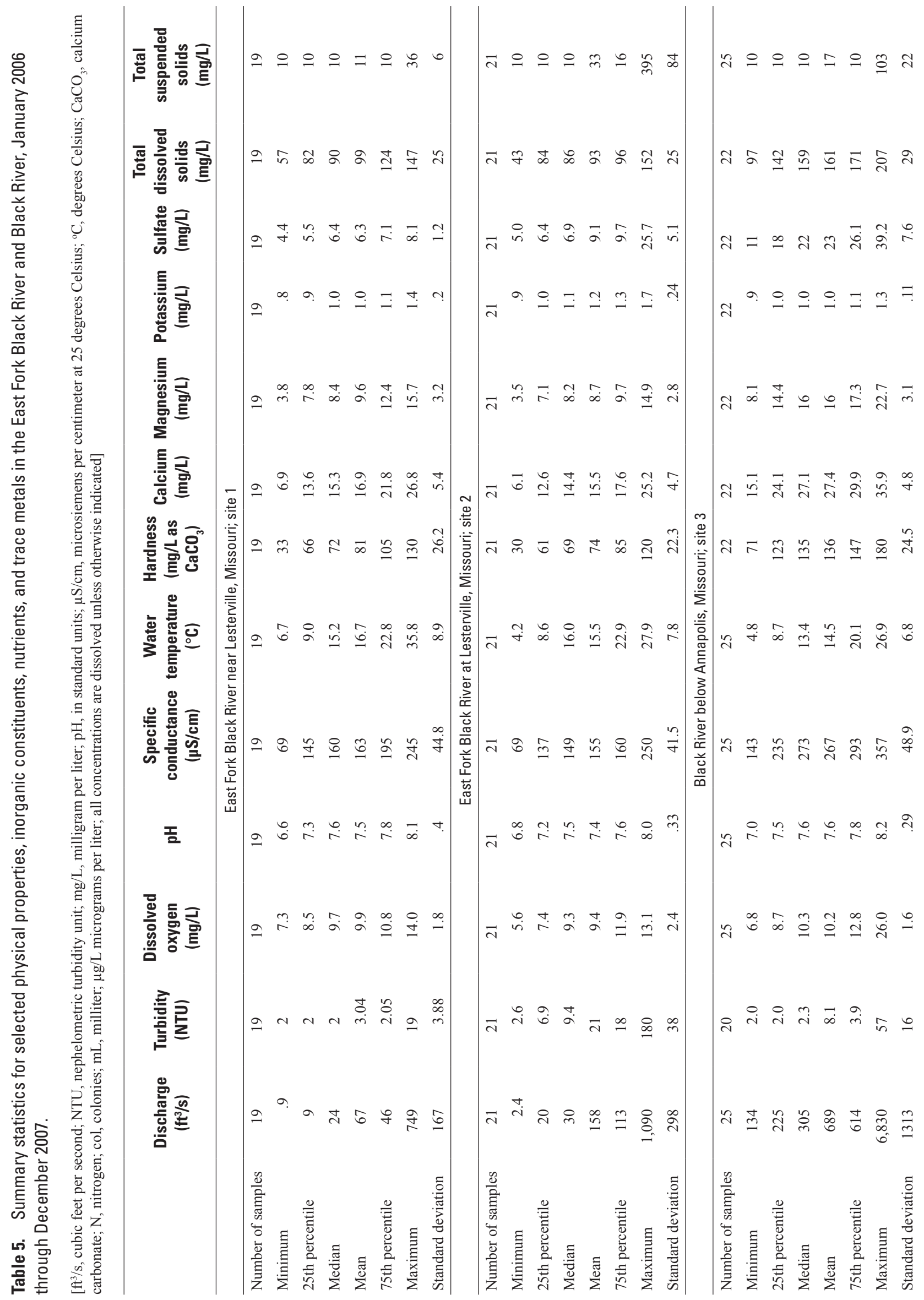




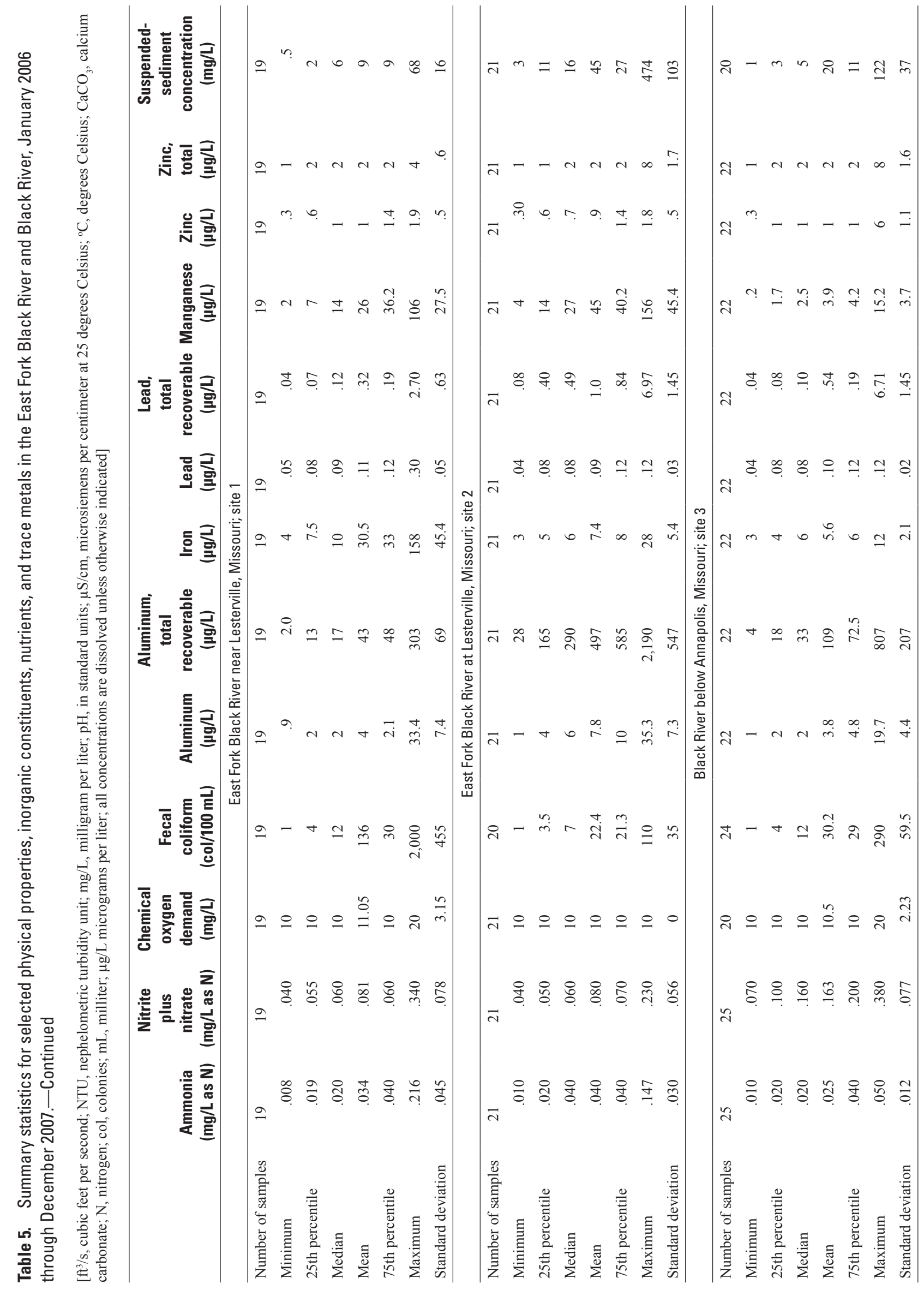



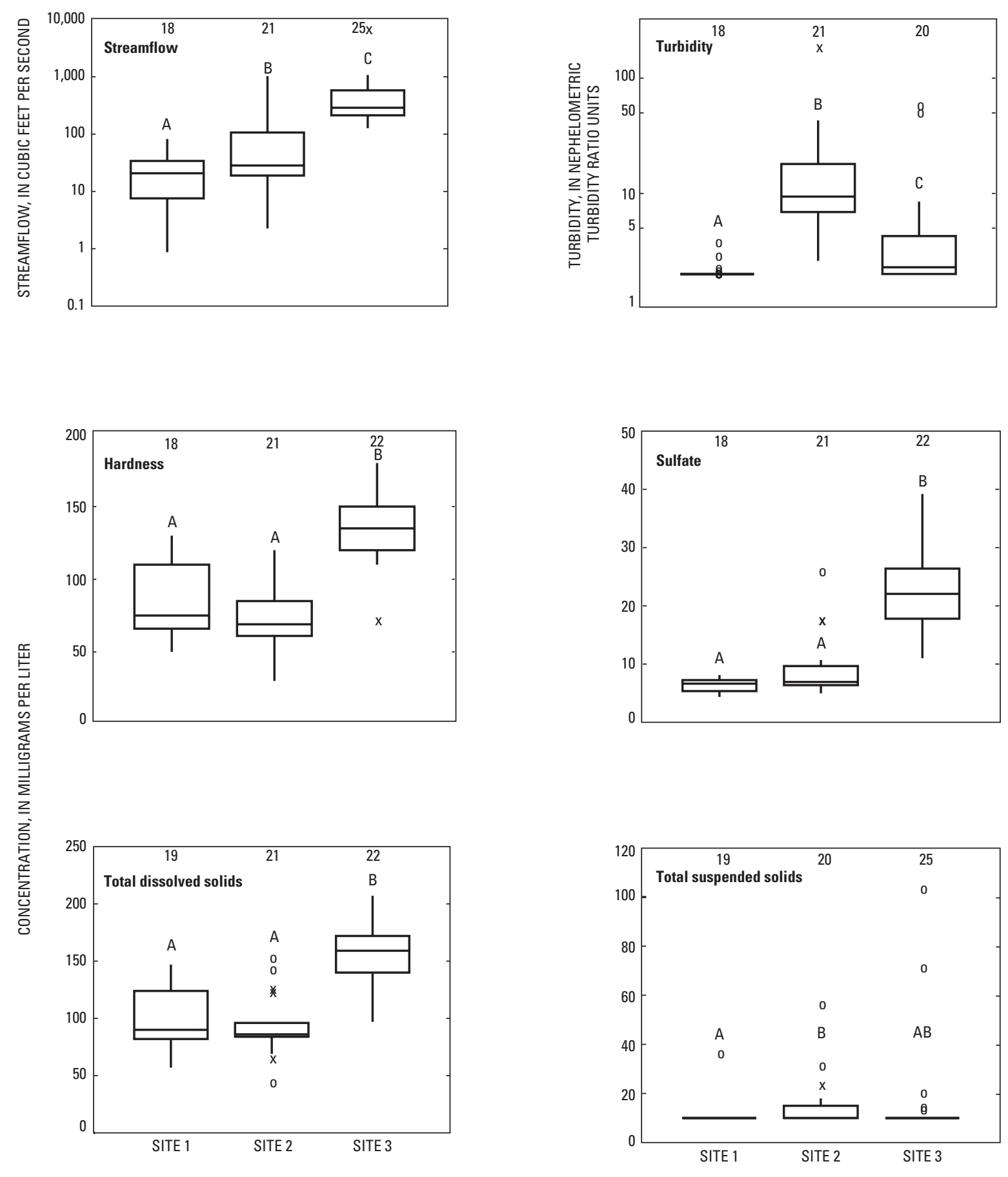

Figure 15. Streamflow, general water-quality, trace elements, and suspended-sediment concentrations for three sampling sites, January 2006 through December 2007. 

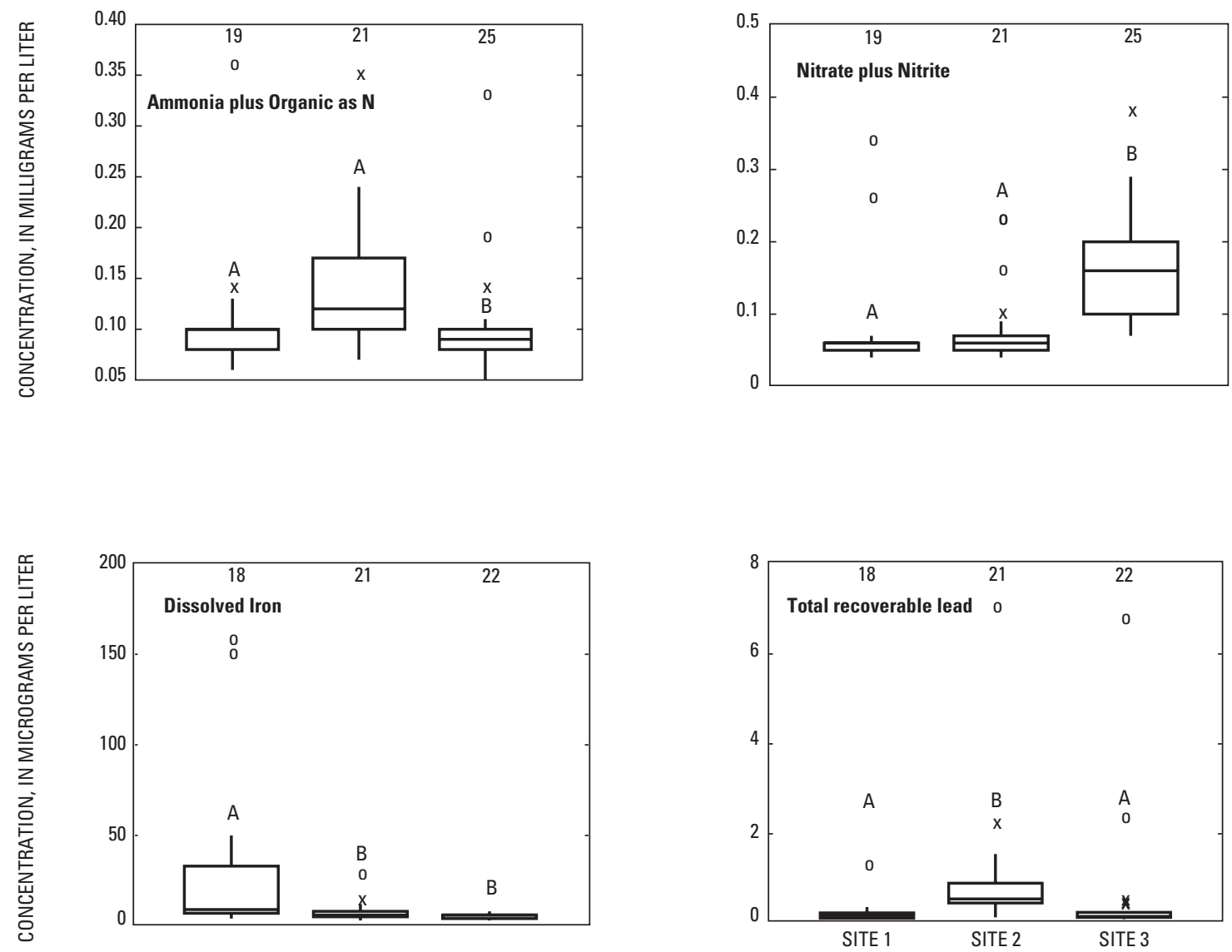

EXPLANATION
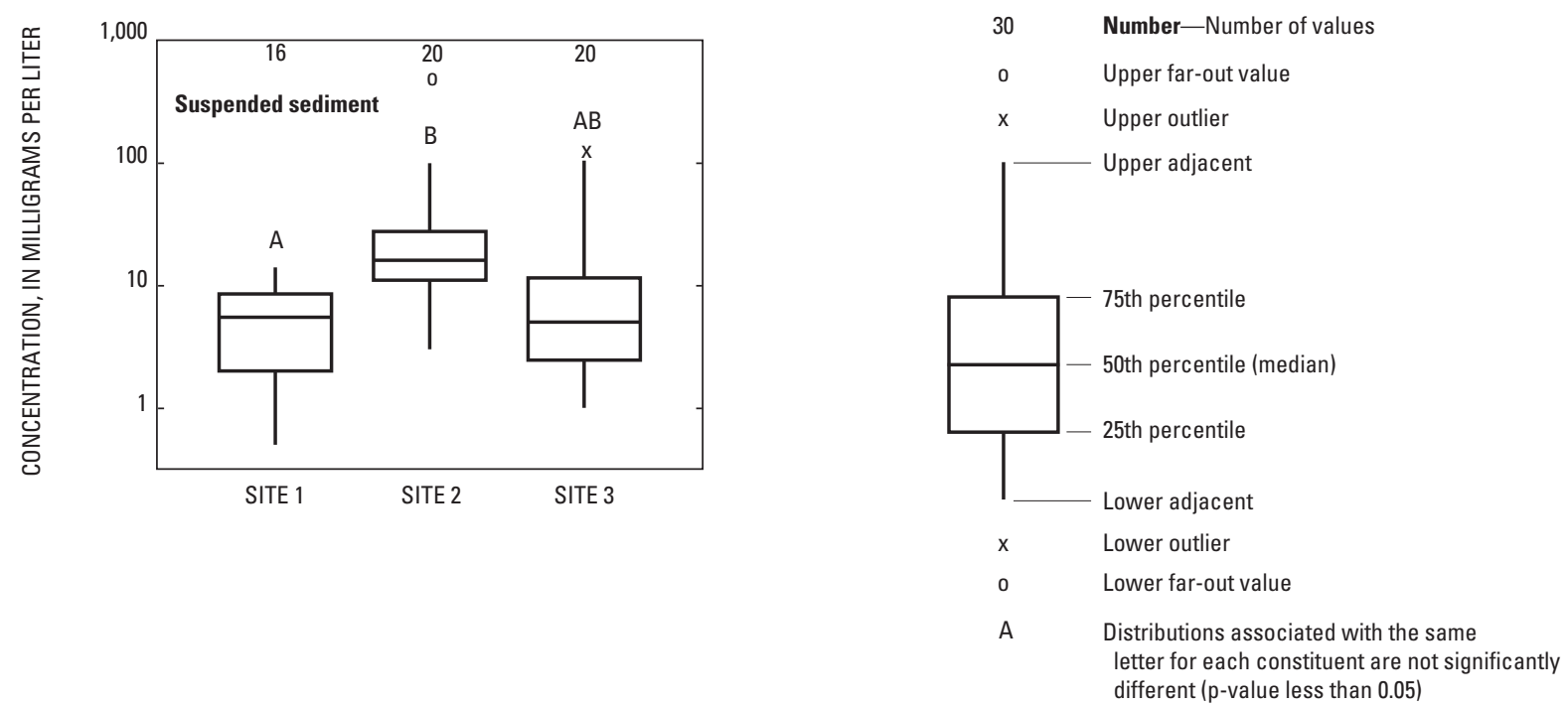

Figure 15. Streamflow, general water quality, trace elements, and suspended-sediment concentrations for three sampling sites, January 2006 through December 2007.-Continued 

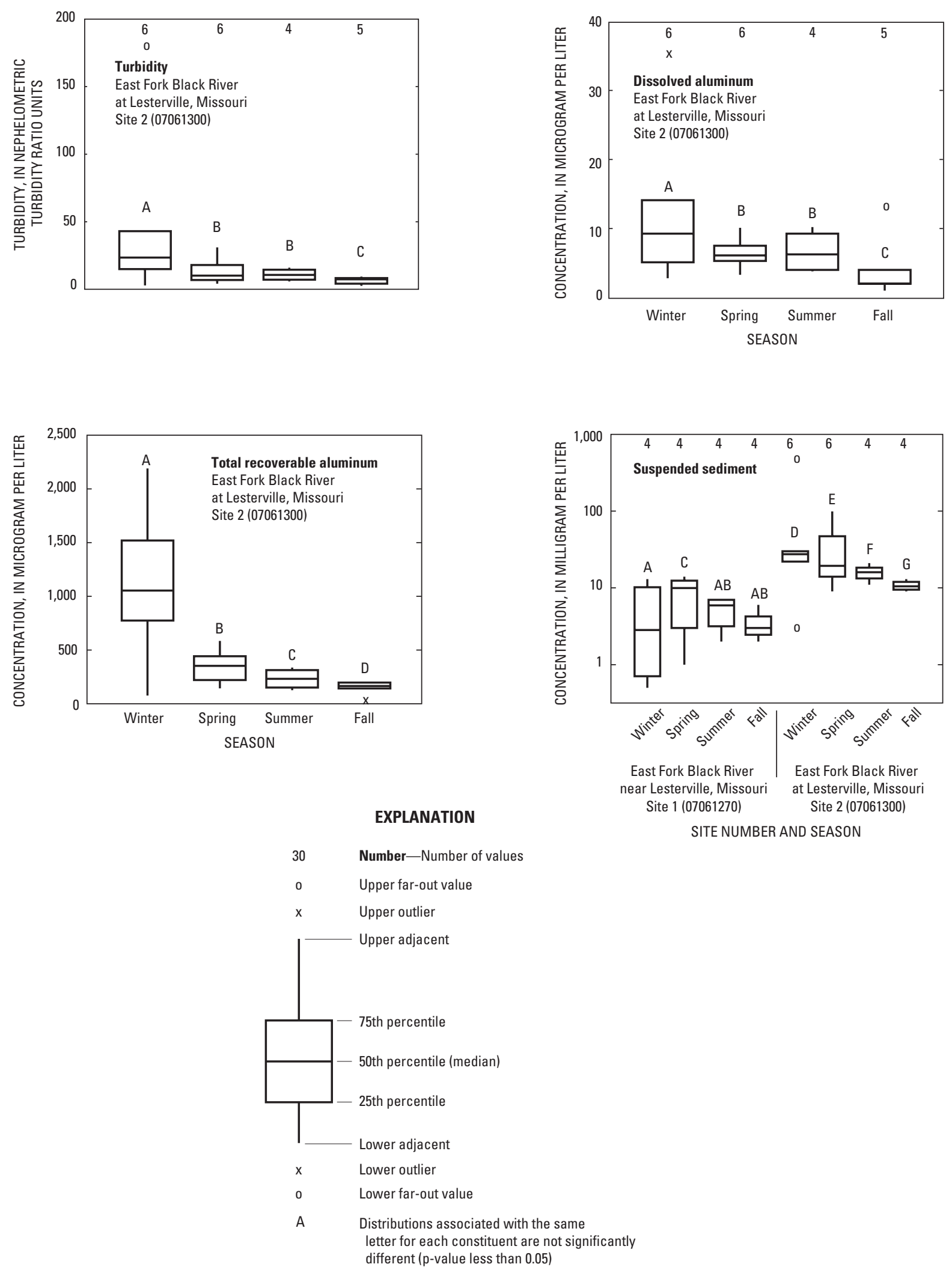

Figure 16. Seasonal trends of discrete surface-water quality cross-section data for turbidity, dissolved and total recoverable aluminum, and suspended-sediment concentrations at sites 1 and 2, January 2006 through December 2007. 
Dissolved and total recoverable aluminum had strong correlation at site $1\left(\mathrm{R}^{2}=0.91\right)$ and site $3\left(\mathrm{R}^{2}=0.78\right)$. The correlation coefficient between dissolved and total aluminum at site 2 was only 0.39 . However, a good correlation was observed between sulfate and total recoverable aluminum $\left(\mathrm{R}^{2}=0.73\right)$ at site 2 (fig. 17). It is possible that the alum-based flocculent used in the lower reservoir was introduced to the East Fork Black River during water releases. If the flocculent was released into the river, it may have been diluted when it reached the main stem of the Black River as there was no correlation between sulfate and total recoverable aluminum at site $3\left(R^{2}=-0.17\right)$. Correlation analyses also were performed between the daily mean turbidity data and the cross-section SSC for each site (fig. 17). The correlation coefficient for site 1 was largest $\left(\mathrm{R}^{2}=0.95\right)$, and the correlation coefficient for site 2 was smallest $\left(R^{2}=0.72\right)$. One data point was removed from the dataset for the correlation analysis for site 2 , which made the $\mathrm{R}^{2}$ value more representative of the entire dataset. Before this data point was removed, the correlation was poor $\left(\mathrm{R}^{2}=0.04\right)$.

Water hardness, TDS, TSS, and SSC were graphically compared to instantaneous streamflow during the study (fig. 18). Generally all three sites show a decrease in water hardness and TDS as the streamflow increased. TSS and SSC increased at sites 2 and 3 as streamflow increased, with the higher concentrations measured during storm events in January and May 2006. Concentrations of $395 \mathrm{mg} / \mathrm{L}$ for TSS and $474 \mathrm{mg} / \mathrm{L}$ for suspended sediment were measured at site 2 in January 2006. No large concentration for either constituent was measured upstream at site 1 in January 2006. The high concentrations for these constituents at site 2 are likely caused by the large amounts of water released from the lower reservoir which tended to cause particles to resuspend in the stream, especially early in the study period, when water was released from the lower sluice. The released water would have carried a large amount of the sediments and debris that flowed downstream into the lower reservoir from the upper reservoir during the embankment breach. Site 3 downstream from site 2 on the Black River had approximately 30 percent less TSS concentration (103 mg/L) and SSC (122 mg/L) than were present at site 2 in January 2006; the East Fork Black River is likely the primary source of these constituents to the main stem of the Black River but become diluted by the influence of the Middle and West Forks.

During the May 2006 event, the SSC at site 1 was approximately 8 times greater than the average SSC of the cross-section samples during the entire study period. The TSS concentration collected during the same event at site 1 was only three times greater than the average concentration during the study period. SSC and TSS concentrations collected at sites 2 and 3 during the same storm event in May 2006 are similar. The large difference in the concentrations of these constituents at site 1 may be because of the difference between analytical methods. It is also possible that the SSC was biased if the sampler touched the streambed at one or more of the subsections causing streambed sediment to enter the sampler nozzle.

\section{Suspended and Streambed Sediments}

The SSC and suspended-sediment discharge data varied during the study period. During the 2006 water year (October 2005 through September 2006), the cross-section SSC ranged from 2 to $68 \mathrm{mg} / \mathrm{L}$ at site 1 and decreased to a range of less than 0.5 to $11 \mathrm{mg} / \mathrm{L}$ during the 2007 water year (October 2006 through September 2007; tables 2, 4, and 5). The total annual sediment discharge for the 2006 water year was 1,240 tons/ yr with a maximum monthly discharge of 870 tons/month in March and a minimum monthly discharge of 0.51 tons/month in August. In water year 2007, the total annual sediment discharge increased to 3,100 tons/yr with a maximum monthly discharge of 1,400 tons/month in February and a minimum monthly discharge of 0.49 tons/month in August (U.S. Geological Survey, 2006b, 2007; fig. 19).

At site 2, the 2006 water year cross-section SSC ranged from 2 to $166 \mathrm{mg} / \mathrm{L}$ and decreased during the 2007 water year, ranging from 3 to $47 \mathrm{mg} / \mathrm{L}$. (tables 2, 4, and 5). The total annual sediment discharge for water year 2006 was 6,100 tons/ yr with a maximum monthly discharge of 2,300 tons/month in March and a minimum monthly discharge of 5.39 tons/month in September. During water year 2007, the total annual sediment discharge increased to 8,100 tons/yr with a maximum monthly discharge of 4,600 tons/month in May and a minimum discharge of 0.61 tons/month in October (U.S. Geological Survey 2006b, 2007; fig. 19).

The mean annual (average of both water years) sediment discharge at site 3 was 15 times greater than site 2 and 40 times greater than the mean annual sediment discharge at site 1 . It is likely that sediment discharges at site 3 are larger because of the influence of the Middle and West Forks of the Black River. The 2006 water year total annual sediment discharge was 29,300 tons/yr with a maximum monthly discharge of 16,000 tons/month in March and a minimum monthly discharge of 39 tons/month in September. For water year 2007, the total annual sediment discharge increased to 174,000 tons/ yr with a maximum monthly discharge of 64,000 tons/month in December and a minimum monthly discharge of 11 tons/ month in August (U.S. Geological Survey, 2006b, 2007; fig. 19). The cross-section SSC ranged from 1 to $122 \mathrm{mg} / \mathrm{L}$ during the 2006 water year and stayed similar during the 2007 water year, ranging from 1 to $83 \mathrm{mg} / \mathrm{L}$ (tables 2, 4, and 5).

The increase in sediment discharge data from water year 2006 to 2007 at all sites could be attributed to several factors: the restoration of the East Fork Black River near site 1, which began approximately April 2006 and continued after the study period; the dredging of the lower Taum Sauk reservoir in August 2006; an increase in storm events from November 2006 through March 2007; and because suspended sediment was not collected from October 2005 through mid-January 2006. It is possible that streambank sediment removed during 

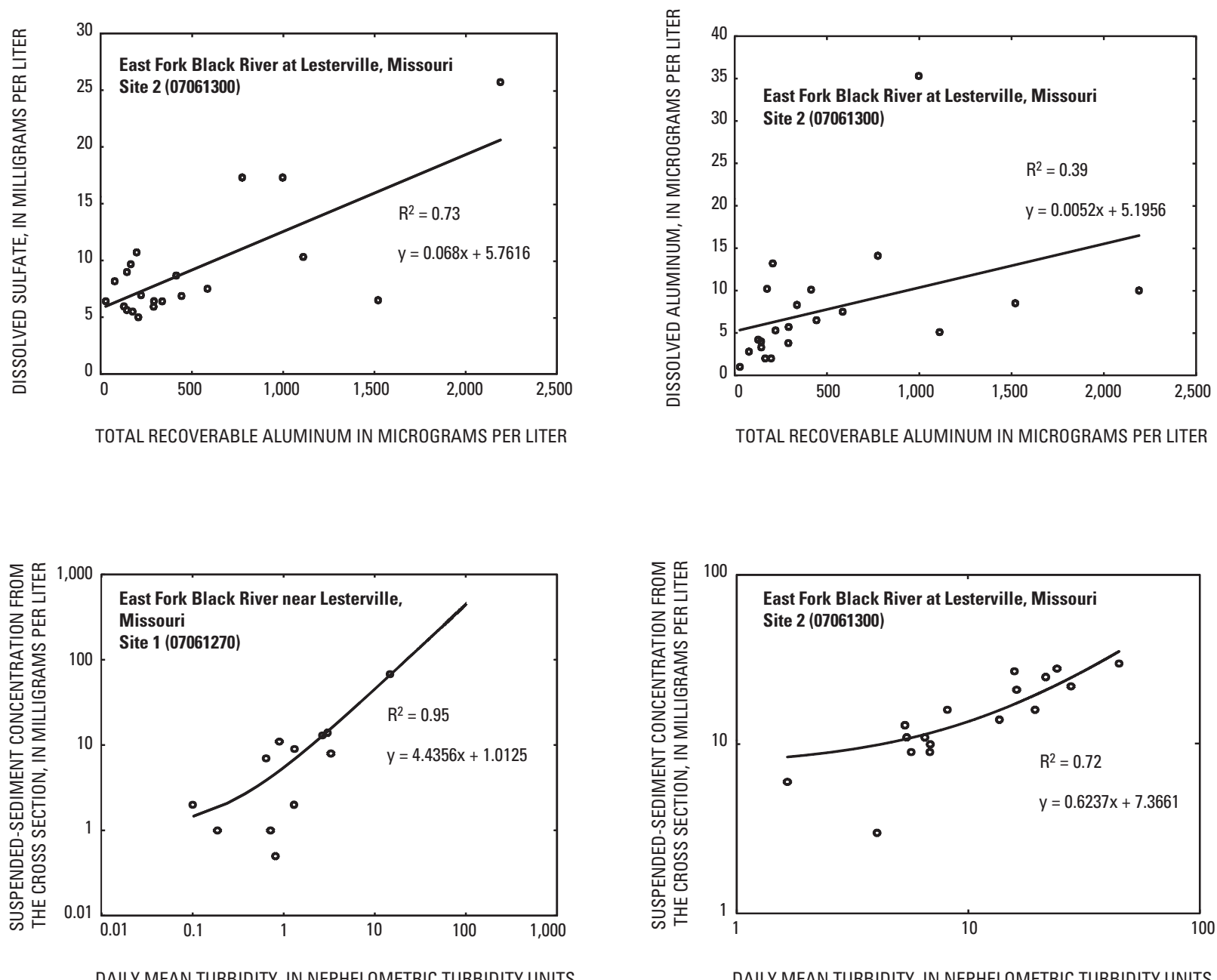

DAILY MEAN TURBIDITY, IN NEPHELOMETRIC TURBIDITY UNITS

DAILY MEAN TURBIDITY, IN NEPHELOMETRIC TURBIDITY UNITS

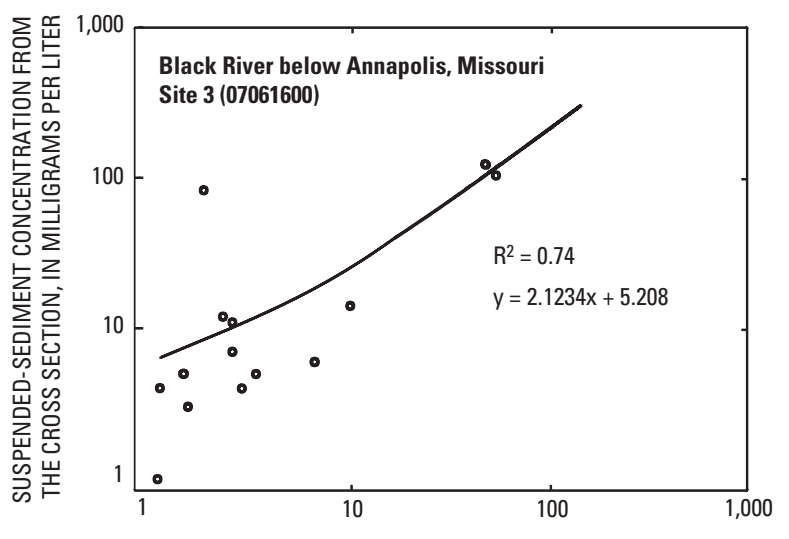

EXPLANATION

$R^{2} \quad$ Correlation coefficient

DAILY MEAN TURBIDITY, IN NEPHELOMETRIC TURBIDITY UNITS

Figure 17. Correlation plots of various surface-water quality constituents. 

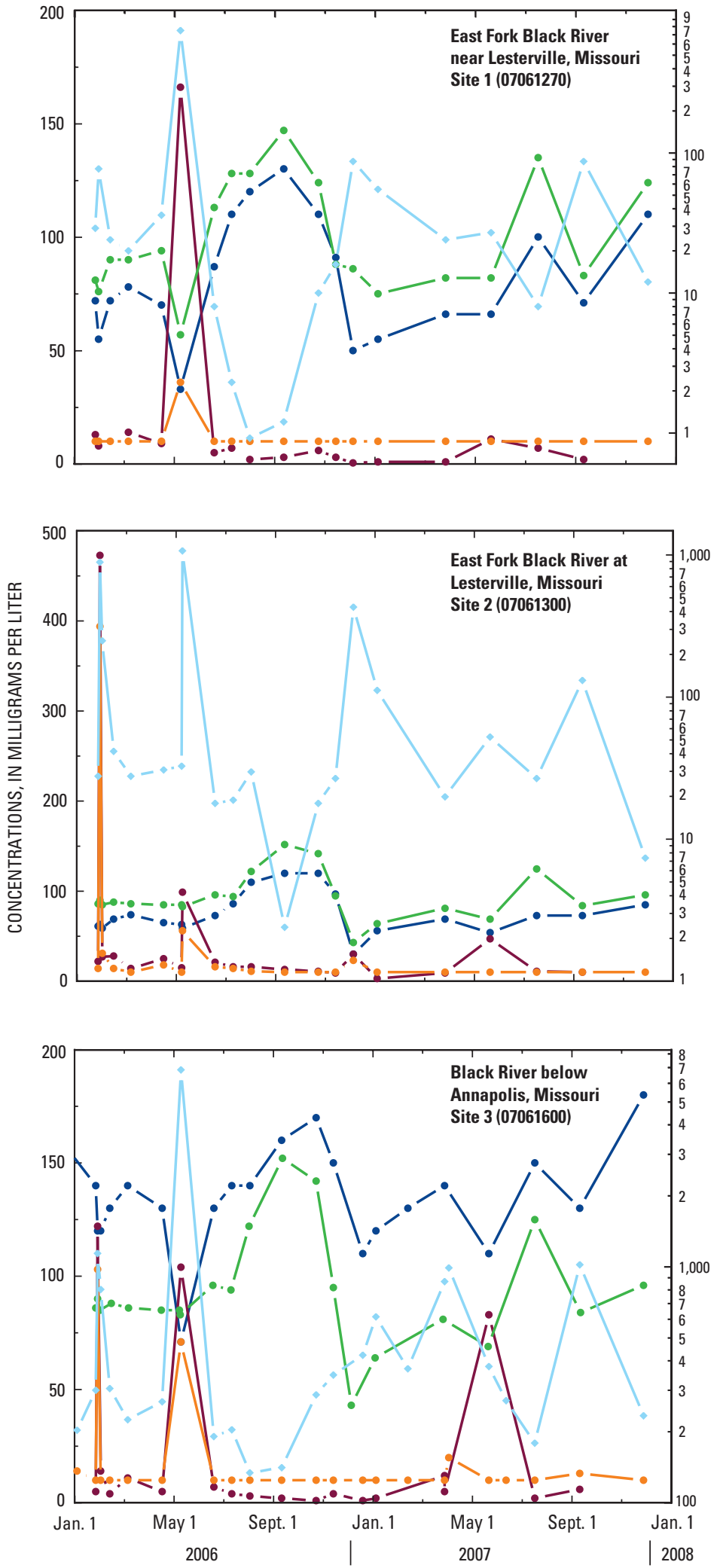

Figure 18. Comparison of surface-water quality constituents with streamflow, January 2006 through December 2007.

\section{EXPLANATION}

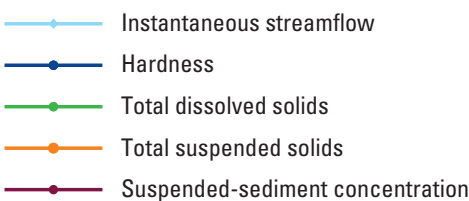

Note: Lines between discrete sampling points and instantaneous streamflow values do not indicate continuous data. They are strictly for the purpose of visualizing trends in the data.

the East Fork Black River reconstruction, as well as bottom materials resuspended during the lower reservoir dredging, could have been remobilized in the stream reaches by runoff during large storm events in November 2006 to January 2007. Figure 19 also shows hydrographs of the daily mean streamflow for each site during the study period. The hydrographs indicate more high-flow events during the 2007 water year than during the 2006 water year. The increase in high flows could have caused more runoff, increasing the suspended-sediment discharge in the second year of the study. Because no sediment data were collected at the three sites during the first three months of the 2006 water year, the annual sediment discharge for the first year of the study may not represent the actual sediment discharge. Sediment discharges would likely be larger during December 2005 and January 2006 because of the upper reservoir embankment breach.

Suspended-sediment and streambed-sediment samples were sent to the USGS Mineral Resource Laboratory in Lakewood, Colorado, for ICP-MS chemical analysis (table 6). A suspended-sediment sample also was collected from the surface of the lower Taum Sauk reservoir shortly after the embankment breach to document early surface-water quality. Larger concentrations of calcium, potassium, aluminum, and iron were measured in the lower reservoir suspended-sediment sample compared to the suspended-sediment samples from the sampling network. The suspended-sediment sample from the lower reservoir was collected prior to the use of the alum flocculent. The suspended-sediment samples from the three sampling sites were collected after the alum flocculent was used and after the lower reservoir release of captured water during the upper reservoir embankment breach.

The suspended-sediment samples were collected during storm events and the streambed sediment was collected during low-flow periods in the summer of 2006. The suspended-sediment aluminum concentrations from site 2 were about 1.4 times larger than the streambed-sediment aluminum concentrations, which 

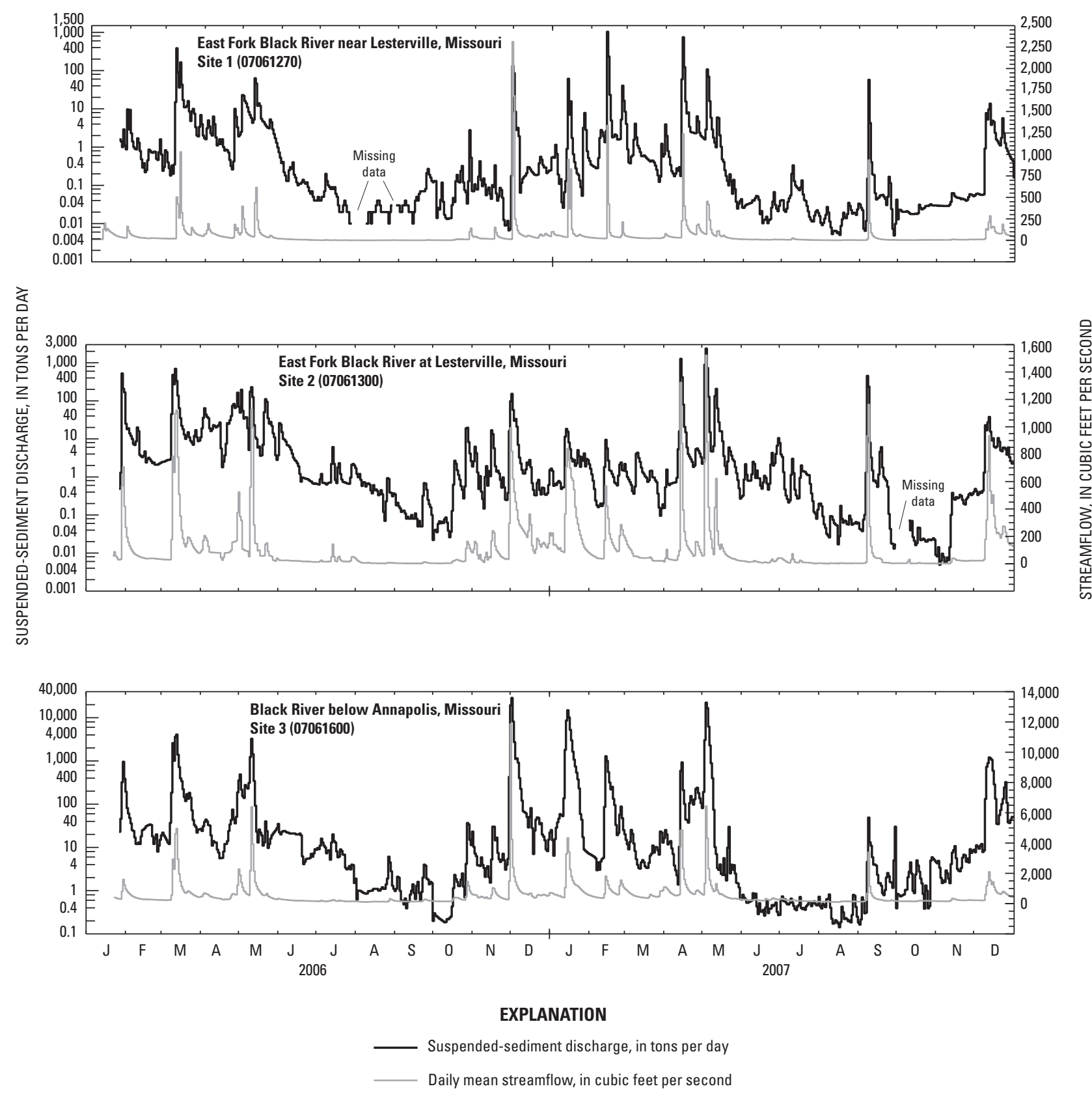

Figure 19. Suspended-sediment discharge in relation to daily mean streamflow, January 2006 through December 2007.

is likely the result of the alum flocculent in the lower reservoir. The suspended-sediment samples collected in October 2006 and January 2007 at sites 1 and 2 show larger concentrations of calcium, arsenic, and strontium than the streambed-sediment samples. The cause of the larger concentrations in the suspended sediments is unknown.

Particle-size analyses of the streambed-sediment samples also were performed, and the results are shown in table 7 . The first sample collected in May 2006 at sites 1 and 2 had the largest silt and clay content. Later samples had much less silt and clay, indicating that much of the finer material had been transported during storm events.
Site 3 has the longest period of record in this study. Historical sediment data from the 1993-97 NAWQA study were available for several of the same constituents analyzed during this study (Davis and others, 1995). These data and data from the current study were analyzed together to identify any trends before or after the embankment breach. The instantaneous streamflow values and SSC data collected in the cross section were used to calculate suspended-sediment discharge.

The nonparametric Kendall's tau test was performed to determine if there was a significant difference (p-value $<$ 0.05 ) in the SSC and suspended-sediment discharge with time. There was no significant difference found between the historical data and the current data $(\mathrm{p}$-value $=0.69)$ for suspended- 


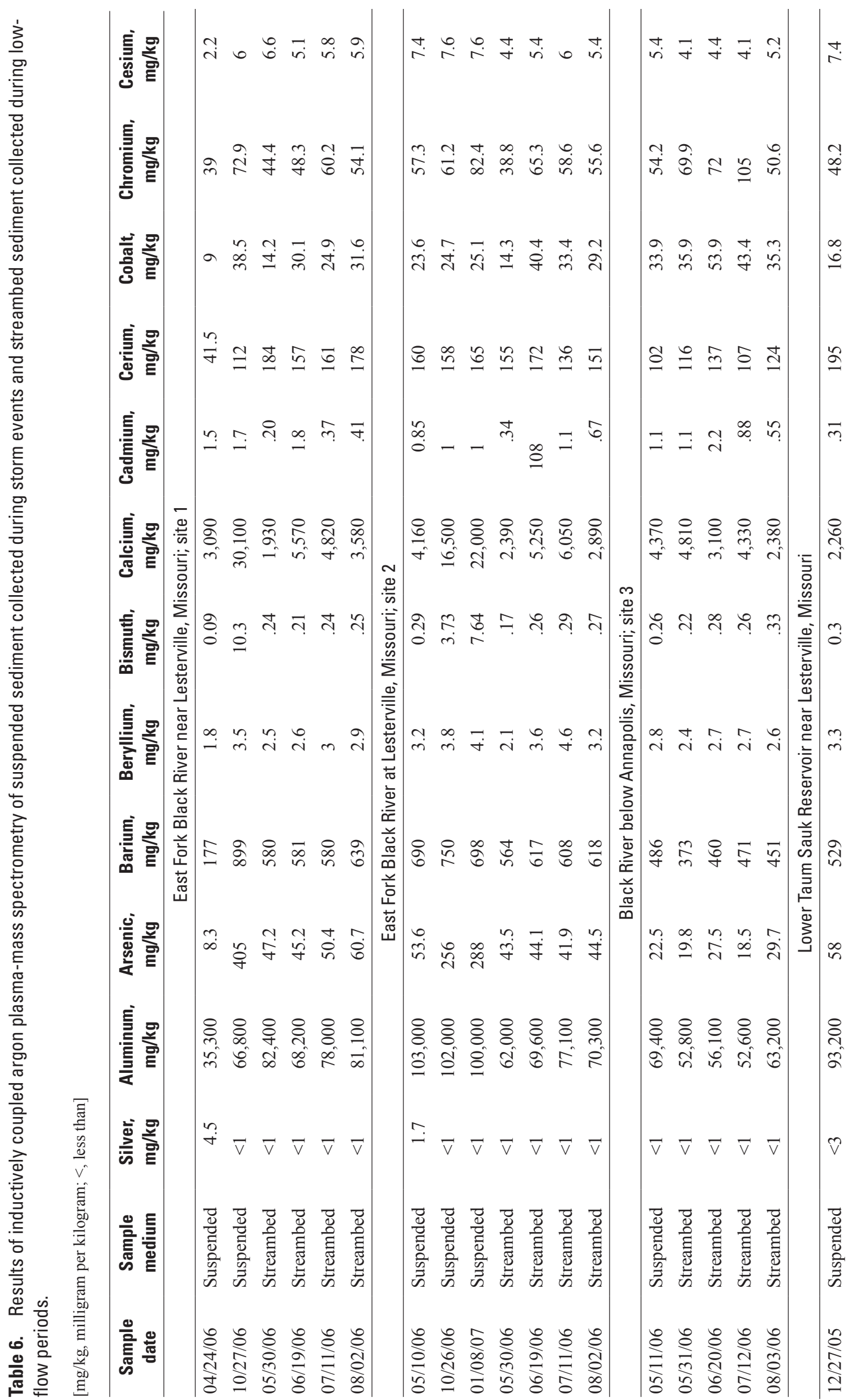




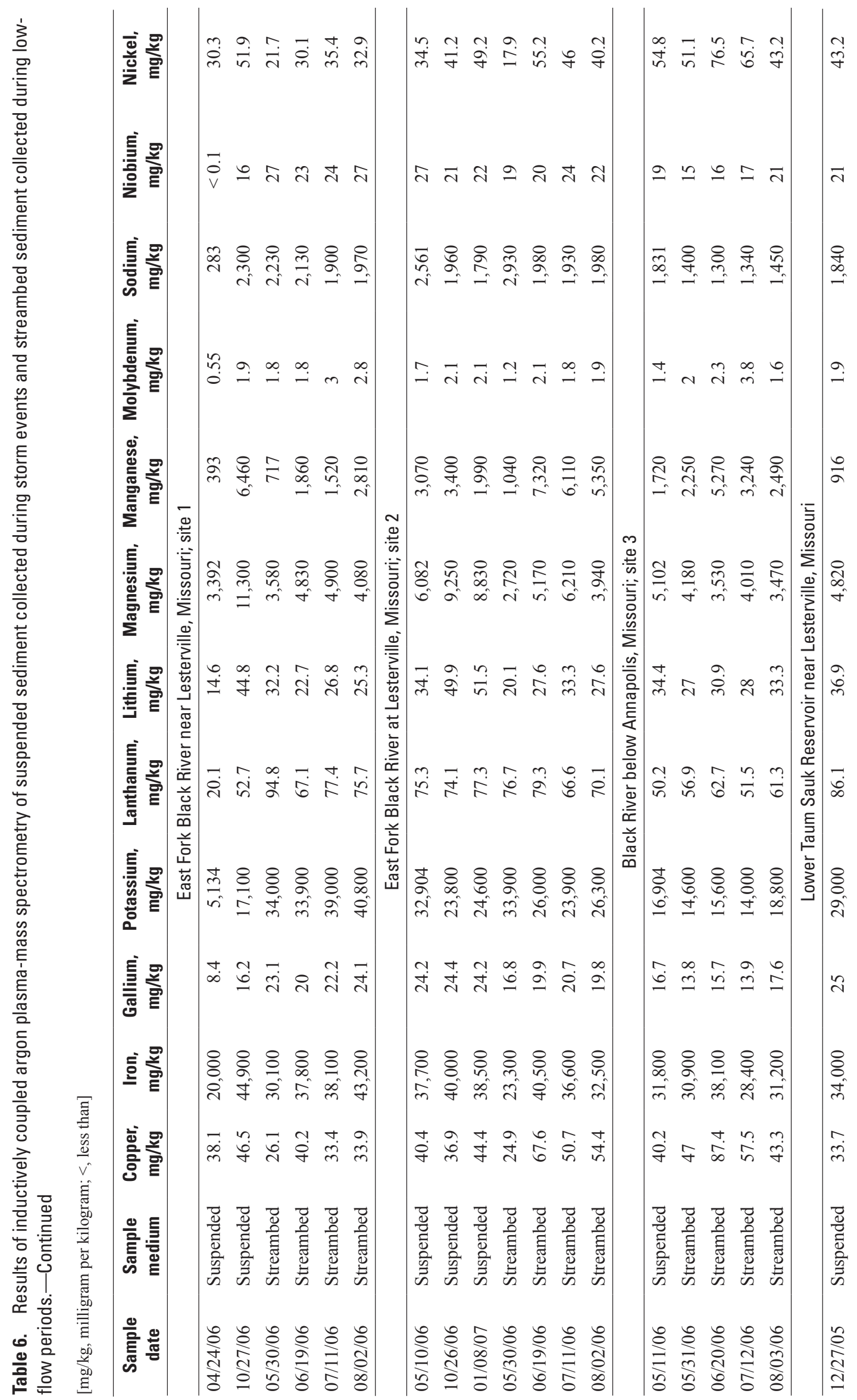




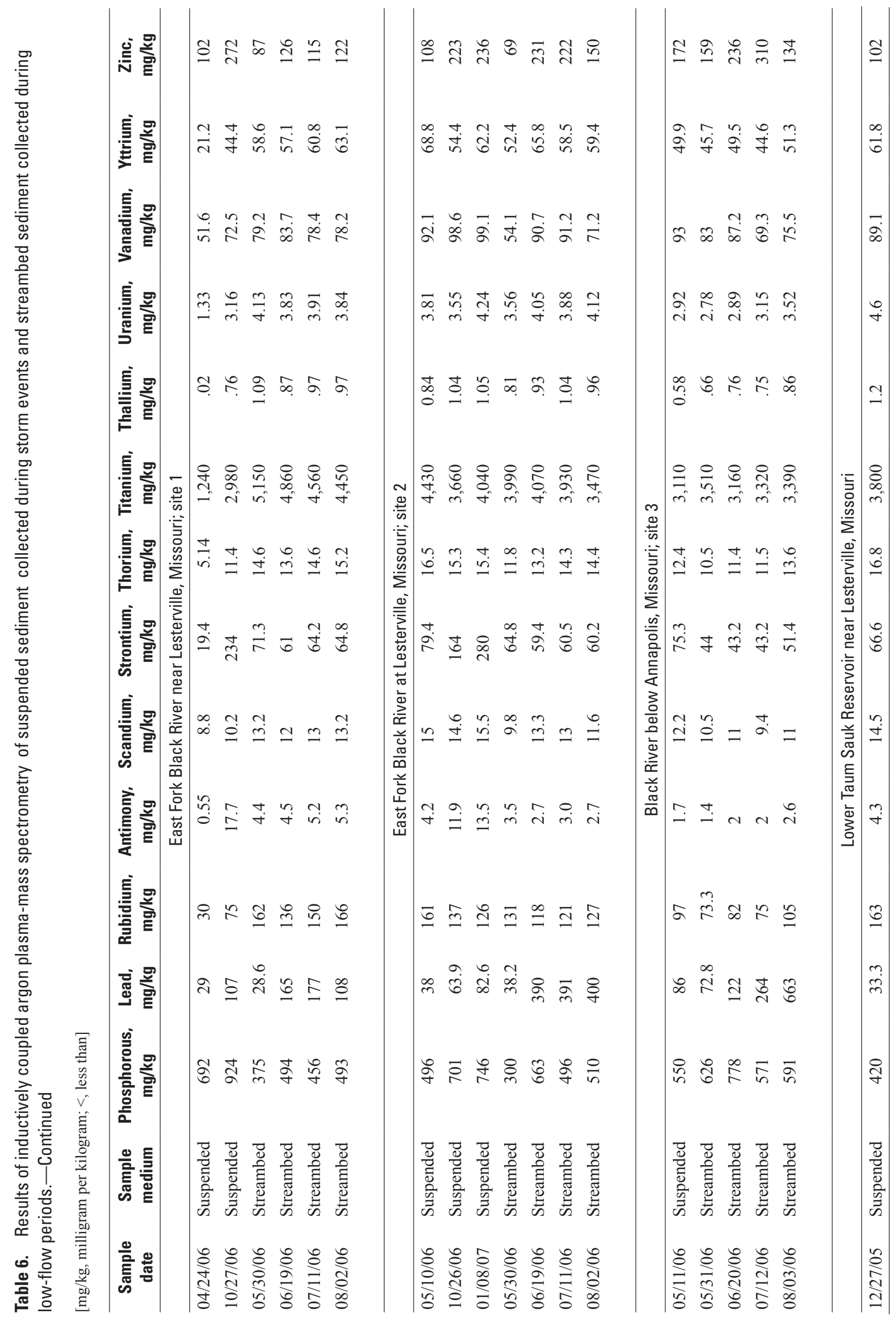


sediment discharge. Kendall's tau was not applicable to the SSC data because of numerous tied (identical) values in the dataset at the minimum reporting level (MRL) of $0.5 \mathrm{mg} / \mathrm{L}$. The historical SSC, TSS, and suspended-sediment discharge data were statistically compared to the current data by using the Wilcoxon rank-sum test to look for trends (fig. 20). Large p-values ( 0.29 for SSC, 0.57 for TSS, and 0.74 for suspendedsediment discharge) indicated that no significant differences were present between the historical and current data. Few differences appear between the streamflow boxplots for site 3 from before and after the reservoir embankment breach in December 2005 (p-value $=0.45$ ). More data outliers are evident before the breach, most of which are from flood events during 1993. Although the SSC data were not significantly different before and after the breach, the median SSC increased and the median suspended-sediment discharge decreased slightly after the embankment breach. The median streamflow did not change before or after the embankment breach. Because the suspended-sediment discharge decreased after the embankment breach while SSC increased, the suspended-sediment discharge seems to be more influenced by streamflow, possibly because the stream velocity is large enough to rapidly transport suspended sediments out of the system.

SSC also were plotted based on instantaneous streamflow ranges (base flow, median flow and high flow) at site 3 to better observe changes that may have occurred from before to after the reservoir embankment breach (fig. 21). The three ranges of streamflow were based on the summary statistics for site 3 (table 5). Most sediment samples collected during the 1993-95 study at site 3 were collected at a median flow (300 to $1,000 \mathrm{ft}^{3} / \mathrm{s}$ ). The samples collected during the 2006-07 study were evenly distributed between base (less than 300 $\mathrm{ft}^{3} / \mathrm{s}$ ) and median flows. Few data are available from both studies for high flows (greater than 1,000 ft3 $/ \mathrm{s}$ ). The base flow SSC for both studies are similar in concentration, with median values of $20 \mathrm{mg} / \mathrm{L}$ for the 1993-95 collection period and $4 \mathrm{mg} / \mathrm{L}$ for the 2006-07 period. A slight increase in SSC at median flow is evident, but only half as many samples were collected in this streamflow range during the current study than in the historical dataset. The median concentration could be skewed slightly in the 2006-07 data because fewer samples were collected than the 1993-95 dataset. A similar situation also is detected for the high streamflow data. The upper far-out value is shown in figure 21 for the historical data set, but the rest of the data are equally distributed in the data range. The current study data have only three values and are shown as individual values in figure 21. The largest SSC measured at site 3 was $270 \mathrm{mg} / \mathrm{L}$ at a streamflow of $28,800 \mathrm{ft}^{3} / \mathrm{s}$ in 1994 . The highest measured concentration during the current study was 122 $\mathrm{mg} / \mathrm{L}$ with a streamflow of $1,140 \mathrm{ft}^{3} / \mathrm{s}$ in January 2006 .

It was noted from January 2006 to approximately November 2007 that the East Fork Black River downstream from the lower Taum Sauk reservoir and the lower reservoir itself appeared to have a peculiar color ranging from bluegreen to dark brown (fig. 22). This discoloration may have been caused by a phenomenon known as "rock flour", which

Table 7. Results of sediment particle-size analyses of streambed sediments used in inductively coupled argon plasma-mass spectrometry analyses.

$[\%$, percent; $<$, less than; $\mathrm{mm}$, millimeter]

\begin{tabular}{|c|c|c|c|c|c|c|c|}
\hline \multirow[b]{2}{*}{$\begin{array}{l}\text { Sample } \\
\text { date }\end{array}$} & \multicolumn{4}{|c|}{ Weights in grams } & \multicolumn{3}{|c|}{ Percent (normalized to $100 \%$ ) } \\
\hline & $\begin{array}{c}\text { Total } \\
\text { recovered }\end{array}$ & Sand & Silt & Clay & $\begin{array}{c}\text { Sand } \\
(<2-0.063 \mathrm{~mm})\end{array}$ & $\begin{array}{c}\text { Silt } \\
(0.063-0.002 \mathrm{~mm})\end{array}$ & $\begin{array}{c}\text { Clay } \\
(<0.002 \mathrm{~mm})\end{array}$ \\
\hline \multicolumn{8}{|c|}{ East Fork Black River near Lesterville; site 1} \\
\hline $5 / 30 / 2006$ & 31.3 & 8.0 & 15.8 & 7.5 & 25.4 & 50.6 & 24 \\
\hline $6 / 19 / 2006$ & 74.2 & 70.2 & 2.8 & 1.2 & 94.6 & 3.7 & 1.7 \\
\hline $7 / 11 / 2006$ & 31.3 & 29.3 & 1.4 & .6 & 93.6 & 4.4 & 2.0 \\
\hline $8 / 2 / 2006$ & 29.8 & 27.8 & 1.4 & .6 & 93.4 & 4.5 & 2.1 \\
\hline \multicolumn{8}{|c|}{ East Fork Black River at Lesterville; site 2} \\
\hline $5 / 30 / 2006$ & 31.8 & 7.6 & 20.8 & 3.5 & 23.9 & 65.2 & 10.9 \\
\hline $6 / 19 / 2006$ & 65.7 & 64.2 & .9 & .5 & 97.8 & 1.4 & .8 \\
\hline $7 / 11 / 2006$ & 28.0 & 25.6 & 1.5 & .9 & 91.4 & 5.4 & 3.2 \\
\hline $8 / 2 / 2006$ & 32.1 & 31.0 & .8 & .4 & 96.4 & 2.3 & 1.3 \\
\hline \multicolumn{8}{|c|}{ Black River below Annapolis; site 3} \\
\hline $5 / 31 / 2006$ & 52.4 & 50.3 & 1.3 & .9 & 95.9 & 2.5 & 1.6 \\
\hline $6 / 20 / 2006$ & 90.7 & 90.3 & .2 & .2 & 99.5 & .3 & .2 \\
\hline $7 / 11 / 2006$ & 30.3 & 29.7 & .3 & .3 & 98.1 & 1.0 & .8 \\
\hline $8 / 3 / 2006$ & 26.8 & 26.3 & .2 & .2 & 98.4 & .8 & .7 \\
\hline
\end{tabular}



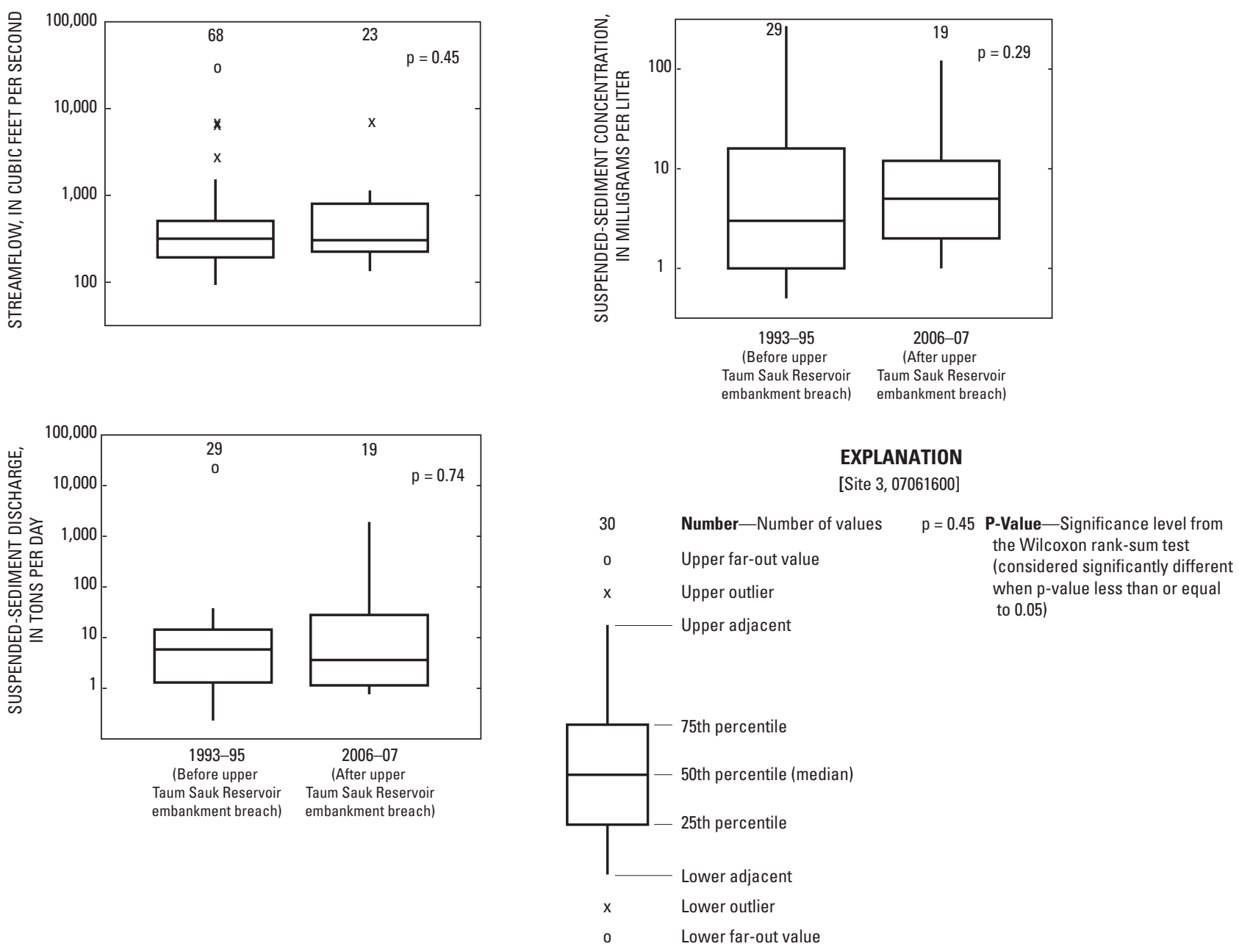

Figure 20. Streamflow, suspended-sediment concentration, and suspended-sediment discharge from Black River below Annapolis, Missouri, 1993-95 and 2006-07.

is defined as the presence of fine-grained, silt and clay-sized sediments formed by a mechanical erosion of bedrock. When the extremely small sediment particles stay suspended in the water, the water body can appear brown, gray, irridecent bluegreen, or milky white (Molina, 2004). Rock flour is typically a glacial term, but the large amount of water that grinded the bedrock of Proffit Mountain during the upper reservoir embankment breach could be the source of the fine silt and clay particles in the East Fork Black River and the lower reservoir. The extremely fine sedment particles stayed suspended in the lower reservoir, which resulted in suspension of the particles in the riverine system downstream as water from the reservoir was released into the stream. The discoloration also could be attributed to the alum-based flocculent that was added to the lower reservoir to rapidly settle out suspended sediments that became trapped in the lower reservoir after the embankment breach. Aluminum sulfate-based flocculent can have a green to white coloration (U.S. Department of Commerce, 2009). Because no baseline data are available for the East Fork Black River prior to the embankment breach, it is difficult to determine the source of the discoloration.

\section{Continuous Water Quality}

The continuous data collected at each site were used to observe daily changes during the study period. These data were published in the USGS annual water data reports summarized as daily extremes (maximum, minimum, mean, and or median; U.S. Geological Survey, 2006b, 2007). Monthly median values were calculated from each daily mean value and used to determine any seasonal trends at the three sites (fig. 23). The streamflow hydrographs showed similar trends at all three sites, but with different flow rates. Similar seasonal trends in both water temperature and dissolved oxygen monthly median values were identified at all three sites. Because all three sites are regionally proximate, the observations are expected. Specific conductance has a seasonal trend at each site with site 3 having values approximately one order of magnitude larger than the other two sites. This may be because site 3 is located on the main stem of the Black River downstream from the junction of the East, Middle, and West Fork Black Rivers. Associated with larger specific conductance measurements at site 3 are increased calcium, 


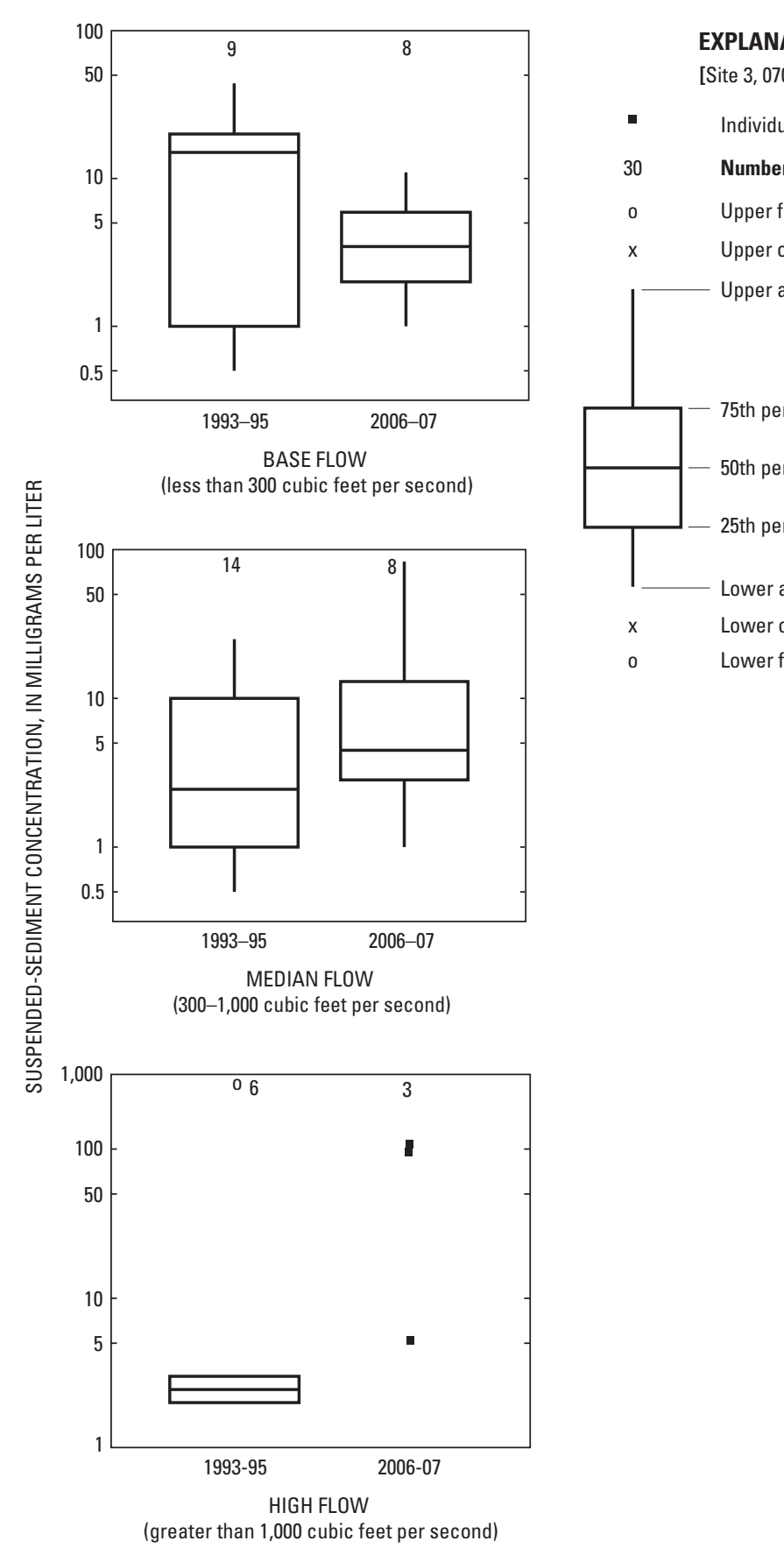

Figure 21. Suspended-sediment concentration data from Black River below Annapolis, Missouri, May 1993 through December 2007.

magnesium, potassium, sulfate, and TDS concentrations (table 5). Water temperature values were higher in the summer months and lower in the winter months. Dissolved oxygen, which is affected by water temperature, was larger in the winter months and smaller in the summer months.

Monthly median turbidity and SSC values were different at each site. These constituents are affected by streamflow, which varies at each site. Monthly median turbidity values were similar at sites 1 and 3 ; however, site 2 had much larger turbidity values. The larger turbidity values could have been caused by the sediments that were captured in the lower Taum Sauk reservoir during the upper Taum Sauk reservoir embankment breach or by the of the alum-base flocculent. Large amounts of water released from the lower reservoir tended to cause particles to resuspend in the stream, especially early in the study period, when water was released from the lower sluice. Over time, the turbidity at this site began to steadily decrease as construction at the lower reservoir also decreased. Monthly median SSC values were much higher at site 2 , which also could be caused by the large amounts of sediment or flocculent released from the lower reservoir. SSCs at site 3 were generally smaller than at site 2 because of dilution by the inflow of the Middle and West Fork Black Rivers. All three sites

show large SSCs early in the study during storm events, which caused runoff and reintroduced fine sediments that had been deposited along the banks from the reservoir embankment breach.

Although long-term effects of the elevated turbidity, major trace metals, and suspended-sediments in the study area as a result of the upper reservoir embankment breach are not expected, there could possibly be other effects not measured during this study that could potentially affect the surface-water quality, such as loss of riparian habitat, changes in biological ecosystems, and large-scale reworking of sediments.

\section{Summary}

On December 14, 2005, a 680-ft wide section of the upper reservoir embankment at the Taum Sauk hydroelectric powerplant located in Reynolds County, Missouri, failed. This failure resulted in the sudden release of approximately 1.5 billion gallons of water from the upper reservoir at the top of Proffit Mountain, down the western slope of the mountain, and into and across the East Fork Black River. The flood wave deposited large quantities of soil, rock, and vegetation into Johnson's Shut-Ins State Park and the downstream reaches of the East Fork Black River. The U.S Geological Survey in collaboration with Ameren United Electric Company evaluated the effects of the embankment breach on the surface-water quality and sediments of the East Fork Black River and the Black River.

The data collection performed by the U.S. Geological Survey encompassed routine, event-based, and continuous surface-water quality monitoring as well as suspended- and streambed-sediment sampling. Surface-water quality samples collected monthly during the first year and bimonthly during the second year, were analyzed for a 


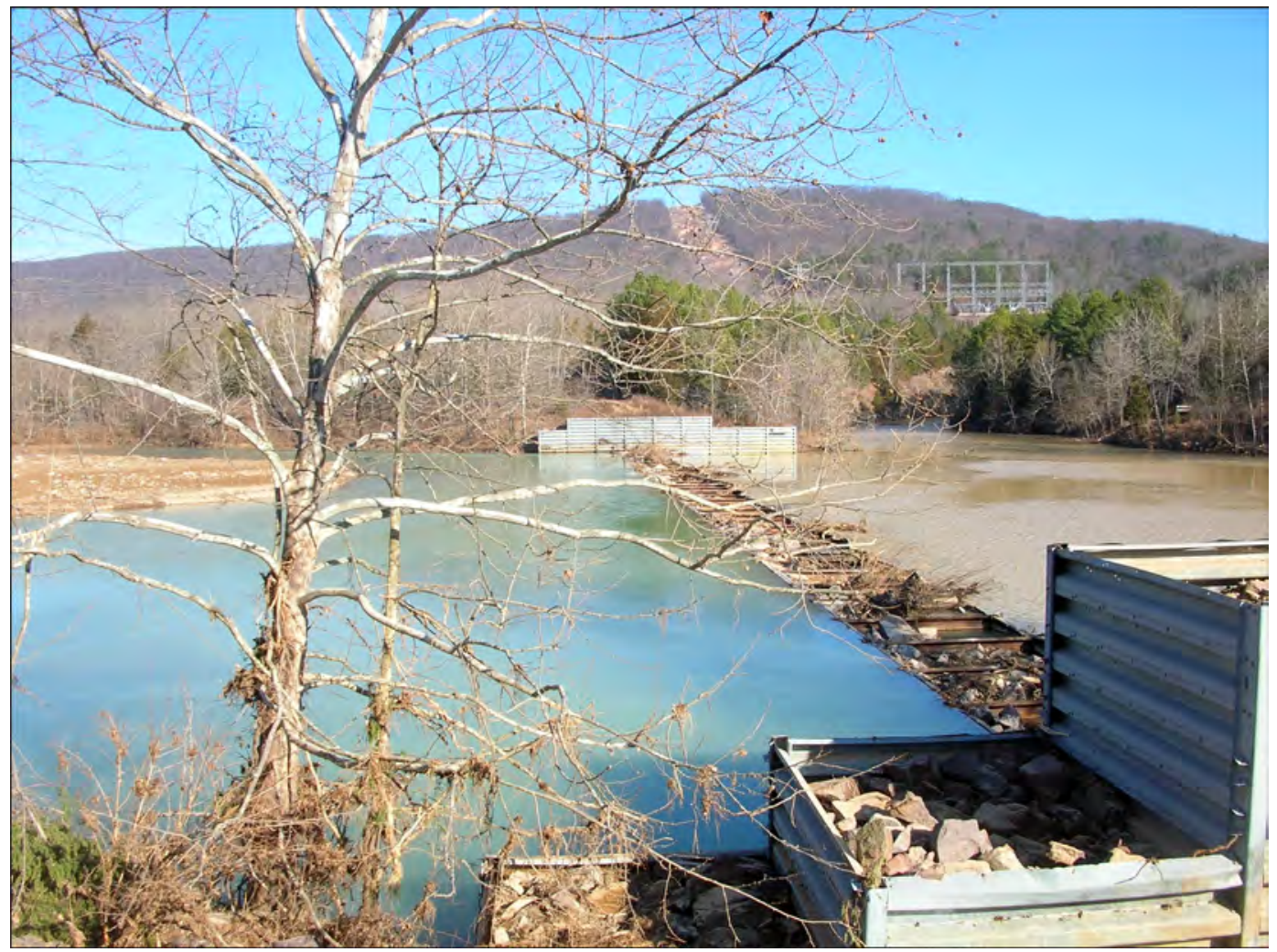

Lower Taum Sauk reservoir near sediment catchment. Note the extreme color difference.

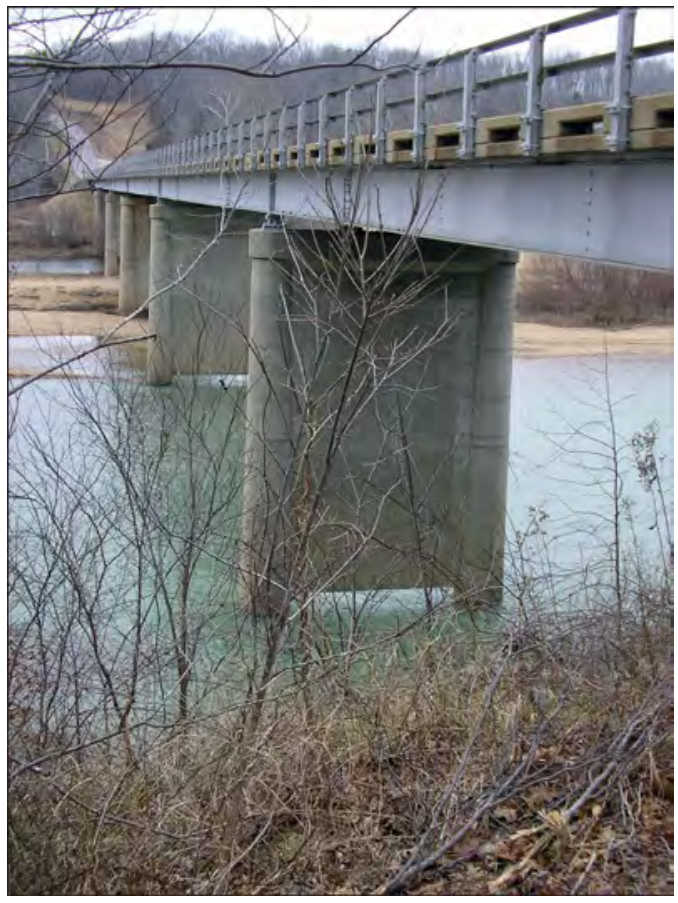

Black River below Annapolis, Missouri, (site 3) at State Highway K, from the left edge of water.

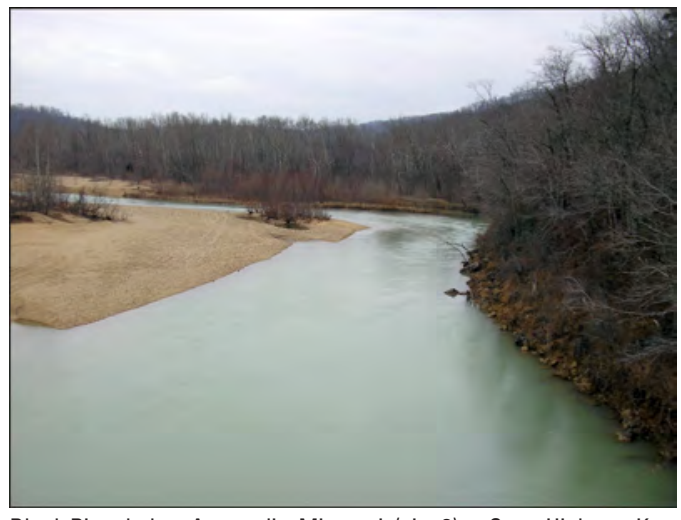

Black River below Annapolis, Missouri, (site 3) at State Highway K, looking upstream.

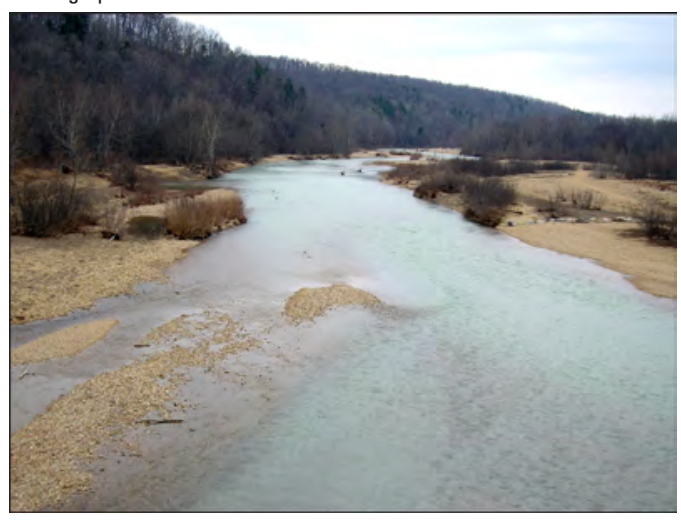

Black River below Annapolis, Missouri, (site 3) at State Highway K, looking downstream.

Figure 22. Photographs of selected stream reaches. 

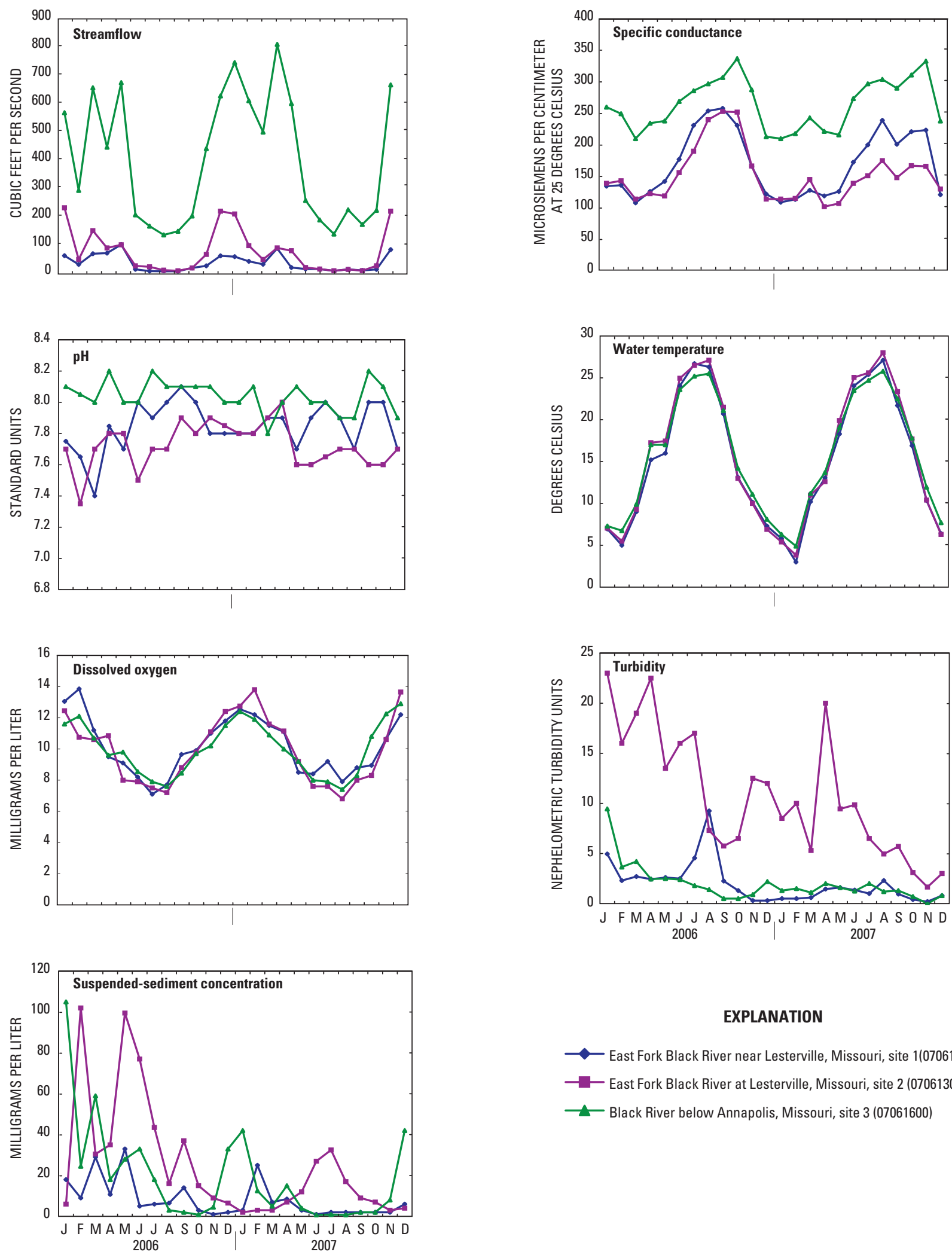

EXPLANATION

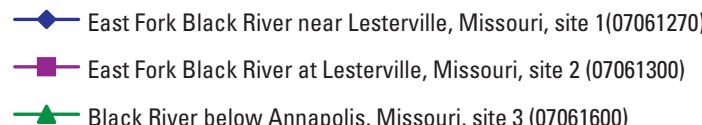

Figure 23. Monthly median values for streamflow, continuous water-quality constituents, and suspended-sediment concentrations. 
suite of physical and chemical constituents including: turbidity; nutrients; major ions such as calcium, magnesium, and potassium; total suspended solids; total dissolved solids; trace metals such as aluminum, iron, and lead; and suspended-sediment concentrations. Daily suspendedsediment discharges were calculated from daily and cross-section suspended-sediment samples. The real-time water-quality monitoring data were provided to the public through the internet on the U.S. Geological Survey's National Water Information System website.

Some similarities in various constituents existed between the sites but not all sites had the same relations. Seasonal trends were evident, mostly at site 2 , for turbidity, dissolved and total recoverable aluminum, and suspended sediment. These constituents showed a gradual decrease from winter to fall collections. Dissolved aluminum showed a slight increase in concentrations during the summer months. This increase could have been from the dredging activity at the lower reservoir which occurred during August 2006. Surface-water cross-section data showed good correlation with related properties, such as streamflow and turbidity, water temperature and dissolved oxygen, and specific conductance and water hardness, which were expected.

Daily SSC were collected at all three sites and used to compute daily suspended-sediment discharge. The range of cross-section SSC decreased at each site over the study period, while the total annual suspended-sediment discharges and annual mean streamflow increased during 2007. The increase in suspended-sediment discharge could be attributed to the large amount of construction along the East Fork Black River in the State park boundary, which began approximately April 2006 and continued after the study ended; dredging of the lower reservoir in August 2006; increased storm events in the spring of 2007; or the few data available during the 2006 water year.

Concentrations of trace metals and major ions also were measured in suspended- and streambed-sediment samples. No significant differences between the suspended-sediment and bed-material data were observed. Samples collected at site 2 showed some elevated concentrations of calcium, phosphorous, aluminum, and strontium in suspended-sediment samples collected during events in October 2006 and January 2007, which could have been caused by the alum-based flocculent used to settle suspended sediments in the lower Taum Sauk reservoir.

Data collected at Black River below Annapolis (site 3), the furthest downstream site, were compared to historical data collected at this site to identify any existing trends in the data from the event. Suspendedsediment concentrations (SSC) were not significantly different before and after the breach, however, the median SSC slightly increased as the median suspendedsediment discharge decreased slightly after the event. The median streamflow showed no change before to after the embankment breach and seems to have a greater influence on the suspended-sediment discharge than the SSC values, possibly because the stream velocity is high and tends to rapidly transport suspended sediments out of the system.

SSC also were observed by three ranges of streamflow; base, median, and high flow, using step- trend analysis with available data before and after the embankment breach. Median SSC collected at base-flow conditions decreased after the embankment breach and increased in median-flow conditions. High-flow conditions were not as easy to determine because only three event samples were collected after the embankment breach.

A peculiar blue-green to brown color was evident along the lower reaches of the East Fork Black River, the lower reservoir, and the Black River from January 2006 to approximately November 2007. It is possible this phenomenon was caused by "rock flour" a result of mechanical erosion of silt and clay-sized sediments as approximately 1.5 billion gallons of water scoured the side of Proffit Mountain during the upper reservoir embankment breach. The coloration could also have been from the alum-based flocculent used to reduce turbidity in the lower Taum Sauk reservoir. The flocculent used was composed primarily of aluminum sulfate, which can have a green to white color. The flocculent may have been introduced to the downstream portion of the East Fork Black River during water releases from the lower reservoir.

The continuous water-quality monitor data were analyzed and proved to be good representations of the entire stream reach at each site, as cross-section measurements of field parameters correlated well with the continuous waterquality monitor data. Median monthly values for specific conductance, water temperature, and dissolved oxygen show similar seasonal trends. Streamflow, turbidity, and SSC were significantly different for each site, mainly because of stream size, deposition, drainage area, and the influence of the lower reservoir. Site 2, located downstream from the lower Taum Sauk reservoir, showed the largest range of turbidity and SSC. The largest turbidity values and SSC were observed in high streamflow samples collected between January and June 2006, then decreased from July 2006 to December 2007, as most of the sediments and debris from the embankment breach were removed from the riverene system.

Although long-term effects of the elevated turbidity, major trace metals, and suspended-sediments in the study area as a result of the upper reservoir embankment breach are not expected, there could possibly be other effects not measured during this study that could potentially affect the surface-water quality, such as loss of riparian habitat, changes in biological ecosystems, and large-scale reworking of sediments. 


\section{References}

Alexander, T.W., and Wilson, G.L., 1995, Techniques for estimating the 2- to 500-year flood discharges on unregulated streams in rural Missouri: U.S. Geological Survey WaterResources Investigations Report 95-4231, 33 p.

American Public Health Association, American Water Works Association, and Water Environment Federation, 1998, Standard methods for the examination of water and wastewater $\left(20^{\text {th }}\right.$ ed.): Washington, D.C., V.2130, p. 2-8 to $2-11$.

Davis, J.V., Petersen, J.C., Adamski, J.C., Freiwald, D.A, 1995, Water-quality assessment of the Ozark Plateaus study unit, Arkansas, Kansas, Missouri, and Oklahoma-Analysis of information on nutrients, suspended sediment, and suspended solids, 1970-92: U.S. Geological Survey WaterResources Investigations Report 95-4042, 120 p.

Edwards, T.K., and Glysson, G.D., 1999, Field methods for measurement of fluvial sediment: U.S. Geological Survey Techniques of Water-Resources Investigations, book 3, chap. C2, 89 p.

Faires, L.M., 1993, Methods of analysis by the U.S. Geological Survey National Water Quality Laboratory-Determination of metals in water by inductively coupled plasma-mass spectrometry: U.S. Geological Survey Open-File Report 92-634, 28 p.

Federal Energy Regulatory Commission, 2006, FERC Taum Sauk investigation team staff report, Report of findings on the overtopping and embankment breach of the upper dam-Taum Sauk pumped storage project: FERC No. 2277, 239 p., accessed November 2008 from http:/www.ferc.gov/ industries/hydropower/safety/projects/taum-sauk/staff-rpt/ full-rpt.pdf

Fenneman, N.M., 1938, Physiography of eastern United States: New York, McGraw-Hill Book Co., Inc., 689 p.

Fishman, M.J., ed., 1993, Methods of analysis by the U.S. Geological Survey National Water Quality LaboratoryDetermination of inorganic and organic constituents in water and fluvial sediments: U.S. Geological Survey OpenFile Report 93-125, 217 p.

Fishman, M.J., and Friedman, L.C., 1989, Methods for determination of inorganic substances in water and fluvial sediments: U.S. Geological Survey Techniques of WaterResources Investigations, book 5, chap. A1, 545 p.

Garbarino, J.R., and Damrau, D.L., 2001, Methods of analysis by the U.S. Geological Survey National Water Quality Laboratory-Determination of organic plus inorganic mercury in filtered and unfiltered natural water with cold vaporatomic fluorescence spectrometry: U.S. Geological Survey Water-Resources Investigations Report 01-4132, 16 p.
Garbarino, J.R., Kanagy, L.K., and Cree, M.E., 2006, Determination of elements in natural-water, biota, sediment, and soil samples using collision/reaction cell inductively coupled plasma-mass spectrometry: U.S. Geological Survey Techniques and Methods, book 5, section B, chap. 1, 88 p.

Garbarino, J.R., and Struzeski, T.M., 1998, Methods of analysis by the U.S. Geological Survey National Water Quality Laboratory-Determination of elements in whole-water digests using inductively coupled plasma-optical emission spectrometry and inductively coupled plasma-mass spectrometry: U.S. Geological Survey Open-File Report 98-165, $101 \mathrm{p}$.

Gray, J.R., Glysson, G.D, Turcois, L.M., and Schwarz, G.E., 2000, Comparability of suspended-sediment concentration and total suspended solids data: U.S. Geological Survey Water-Resources Investigations Report 00-4191, 20 p.

Guy, H.P., 1969, Laboratory theory and methods for sediment analysis: U.S. Geological Survey Techniques of WaterResources Investigations, book 5, chap. C1, 58 p.

Hayes, W.C., and Beveridge, T.R., 1961, Guidebook to the geology of the St. Francois Mountain area: Report of investigations No. 26, October, 1961, State of Missouri Department of Business and Administration, Division of Geological Survey and Water Resources, 137 p.

Helsel, D. R., and Hirsch, R.M., 1992, Statistical methods in water resources: U.S. Geological Survey Techniques of Water-Resources Investigations, book 4, chap. A3, 510 p.

Hendron, A.J., Ehasz, J.L., and Paul, K., 2006, Technical reasons for the breach of December 14, 2005, Taum Sauk Upper Dam Breach: FERC No. P-2277, 134 p.

Koltun, G.F, Eberle, Michael, Gray, J.R., and Glysson, G.D., 2006. User's manual for the Graphical Constituent Loading Analysis System (GCLAS): U.S. Geological Survey Techniques and Methods, book 4, Chap. C1, 51 p.

Molina, B.F., 2004, Glossary of glacier terminology: A glossary providing the vocabulary necessary to understand the modern glacier environment: U.S. Geological Survey Open File Report 2004-1216, accessed October 2008 from http:// pubs.usgs.gov/of/2004/1216/.

Missouri Department of Natural Resources, 2008, Missouri state parks and historic sites website, accessed January 2009 from http://www.mostateparks.com/jshutins/recovery.htm

Missouri Spatial Data Information Service, 2005, Land use/ land cover data: Columbia, Missouri, accessed May 2008 from http://msdis.missouri.edu/.

Myers, D.N., Stoeckel, D.M., Bushon, R.N., Francy, D.S., and Brady, A.M.G., 2007, Fecal indicator bacteria: U.S. Geological Survey Techniques of Water-Resources Investigations, book 9, chap. A7, section 7.1, (ver. 2.0) accessed May 2008 at http://pubs.water.usgs.gov/twri9A7/. 
National Oceanic and Atmospheric Administration, 2006, Climatologic data annual summary, Missouri: Asheville, North Carolina, National Climatic Data Center.

National Oceanic and Atmospheric Administration, 2007, Climatologic data monthly summaries, January through December, Missouri: Asheville, North Carolina, National Climatic Data Center.

Patton, C.J., and Truitt, E.P., 2000, Methods of analysis by the U.S. Geological Survey National Water Quality Laboratory-Determination of ammonium plus organic nitrogen by a Kjeldahl digestion method and an automated photometric finish that includes digest cleanup by gas diffusion: U.S. Geological Survey Open-File Report 00-170, 31 p.

Porterfield, G., 1972. Computation of fluvial-sediment discharge: U.S. Geological Survey Techniques of WaterResources Investigations, book 3, chap. C3, 66 p.

River Valley Region Association, 2008, Missouri vacations website, accessed December 2008 at http://missourivacations.com/johnson's-shutins-state-park/index.htm

Rydlund, Jr., P.H., 2006. Peak discharge, flood profile, flood inundation, and debris movement accompanying the failure of the upper reservoir at the Taum Sauk pump storage facility near Lesterville, Missouri: U.S. Geological Survey Scientific Investigations Report 2006-5284, 48 p.

Struzeski, T.M., DeGiacomo, W.J., and Zayhowski, E.J., 1996, Methods of analysis by the U.S. Geological Survey National Water Quality Laboratory-Determination of dissolved aluminum and boron in water by inductively coupled plasma-atomic emission spectrometry: U.S. Geological Survey Open-File Report 96-149, 17 p.

University of Missouri, 2001, Population for Missouri counties, municipalities, and legislative districts 1990 and 2000: Office of Social and Economic Data Analysis, accessed May 2008 at $h t t p: / / m c d c . m i s s o u r i . e d u$
U.S. Department of Commerce, 2009, National Oceanic and Atmospheric Administration, Office of Response and Restoration, CAMEO chemical database, accessed February 2009 at http://cameochemicals.noaa.gov/ chemical/8226\#section5

U.S. Geological Survey, 1999, Water resources data-Missouri, water year 1999, U.S. Geological Survey Water-Data Report MO-99-1.

U.S. Geological Survey, 2006a, Collection of water samples (ver. 2.0): U.S. Geological Survey Techniques of WaterResources Investigations, book 9, chap. A4, September, accessed April 2008 at http://pubs.water.usgs.gov/ twri9A4/.

U.S. Geological Survey, 2006b, Water resources data of the United States, annual water data report, WDR-US-2006, accessed May 2008 at http://wdr.water.usgs.gov/.

U.S. Geological Survey, 2007, Water resources data of the United States, annual water data report, WDR-US-2007, accessed May 2008 at http://wdr.water.usgs.gov/.

Wagner, R.J. Boulger, R.W., Jr., Oblinger, C.J., and Smith, B.A., 2006, Guidelines and standard procedures for continuous water-quality monitors-Site operation, record computation, and data reporting: U.S. Geological Survey Techniques and Methods 1-D3, 51 p. plus 8 attachments; accessed April 2008 at http://pubs.water. usgs.gov/tm 1 d 3

Wilde, F.D., Radtke, D.B., Gibs, Jacob, and Iwatsubo, R.T., eds., 2004, Processing of water samples (version 2.1): U.S. Geological Survey Techniques of Water-Resources Investigations, book 9, chap. A5, April, accessed April 2008 at http://pubs.water.usgs.gov/twri9A5/.

Wilde, F.D., ed., chapter sections variously dated, Field measurements: U.S. Geological Survey Techniques of WaterResources Investigations, book 9, chap. A6, accessed April 2008 at $h$ ttp://pubs.water.usgs.gov/twri9A6 

Table 2 


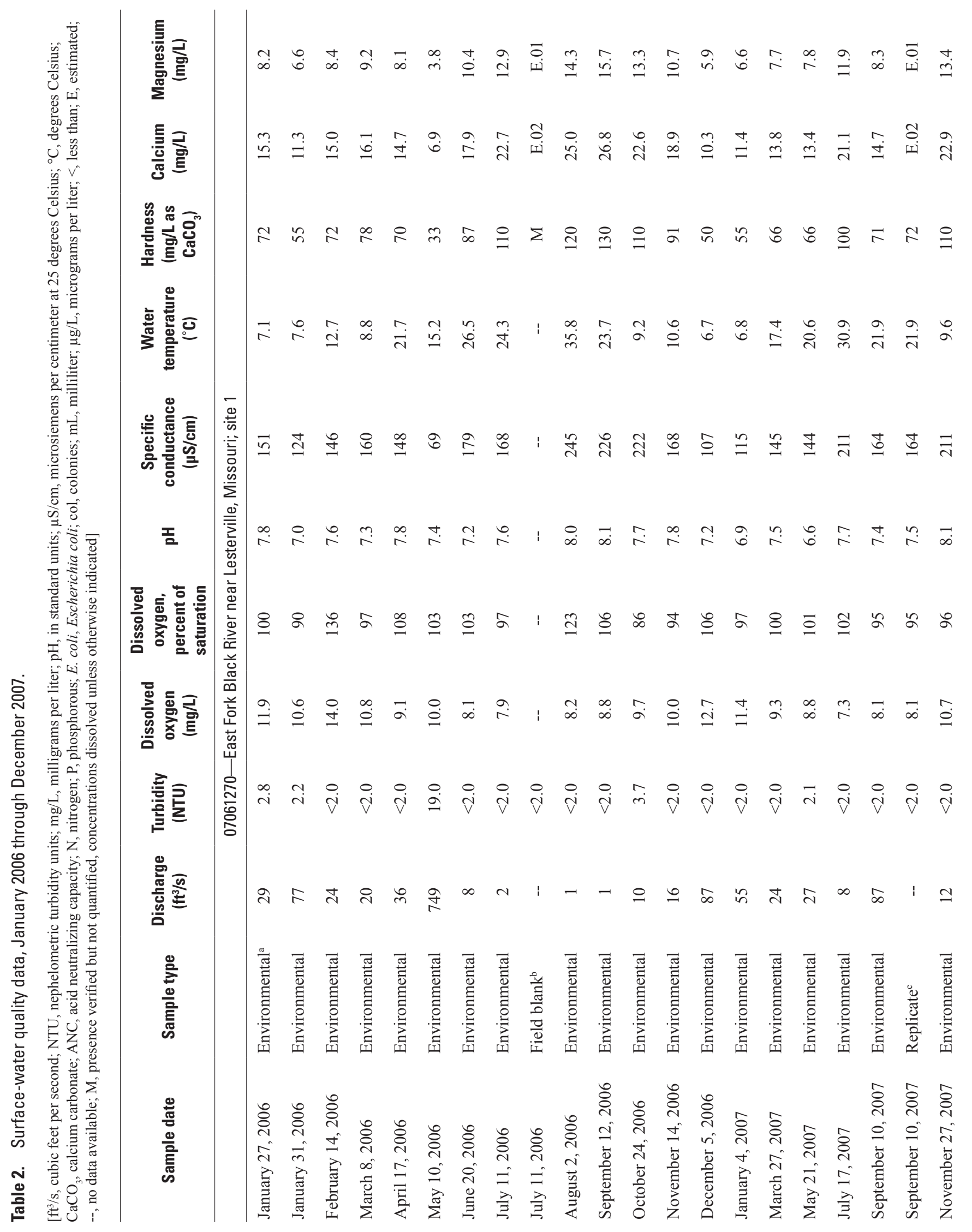




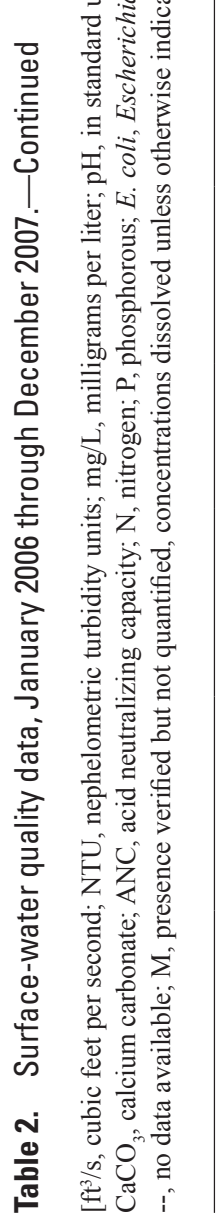

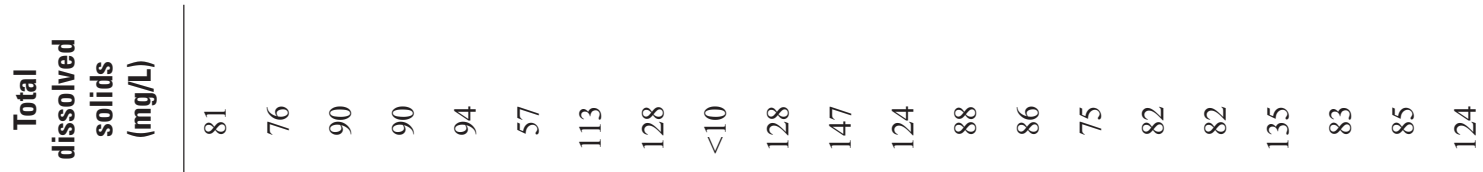

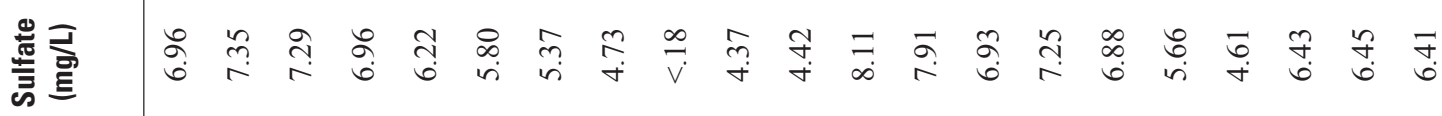

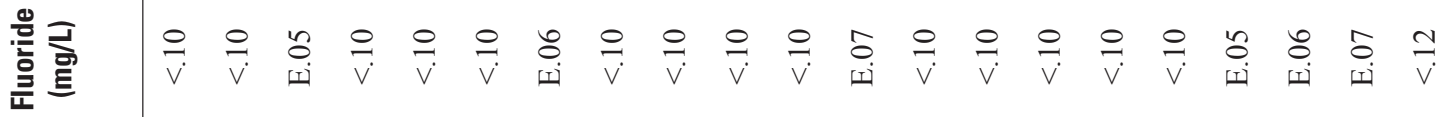

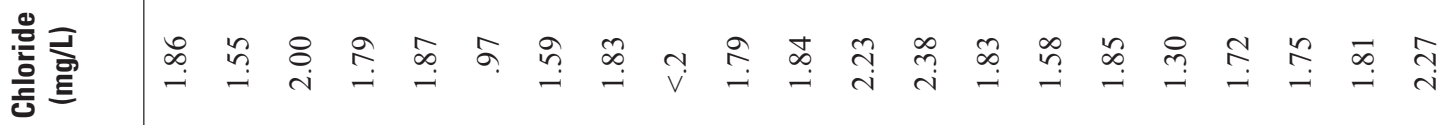

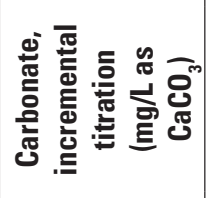

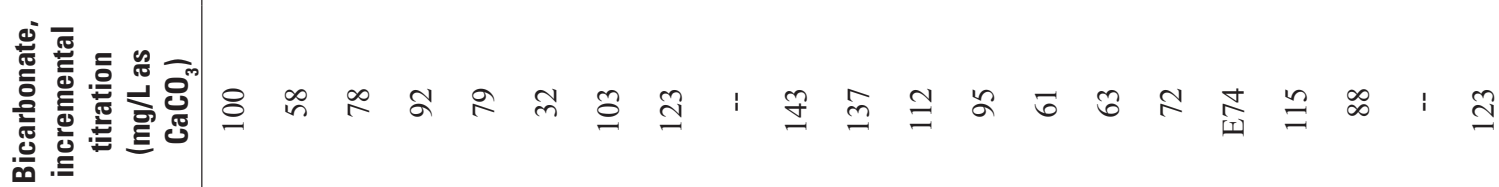

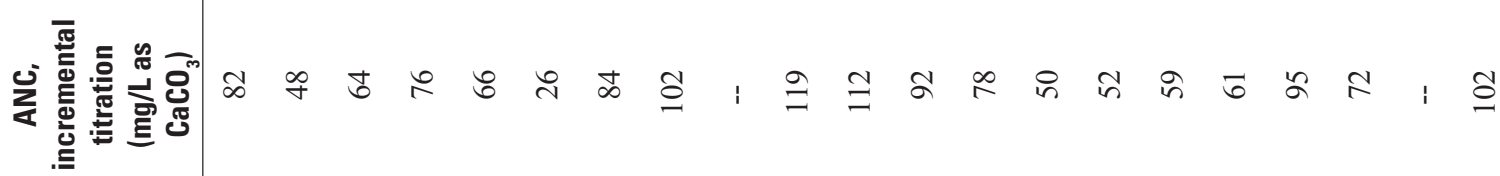

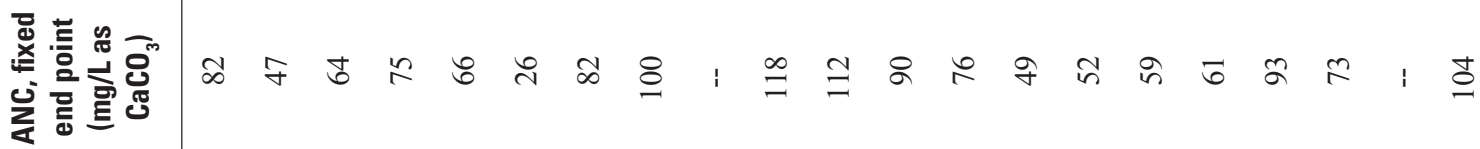

$$
\begin{aligned}
& \text { 衰需 }
\end{aligned}
$$

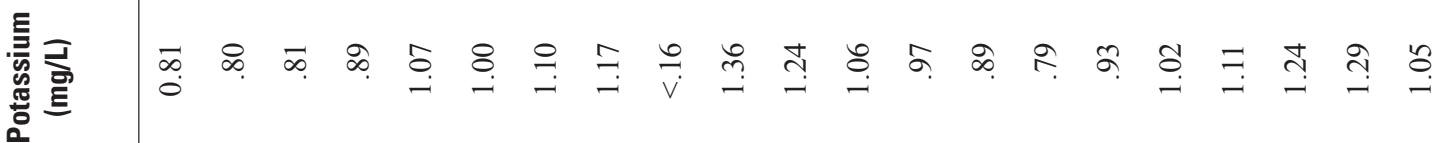

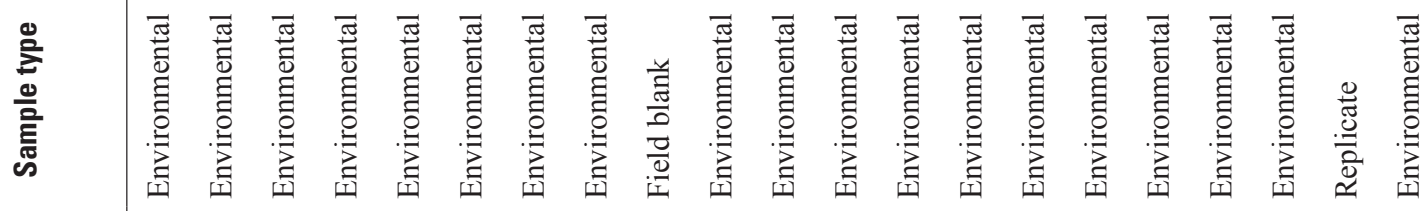

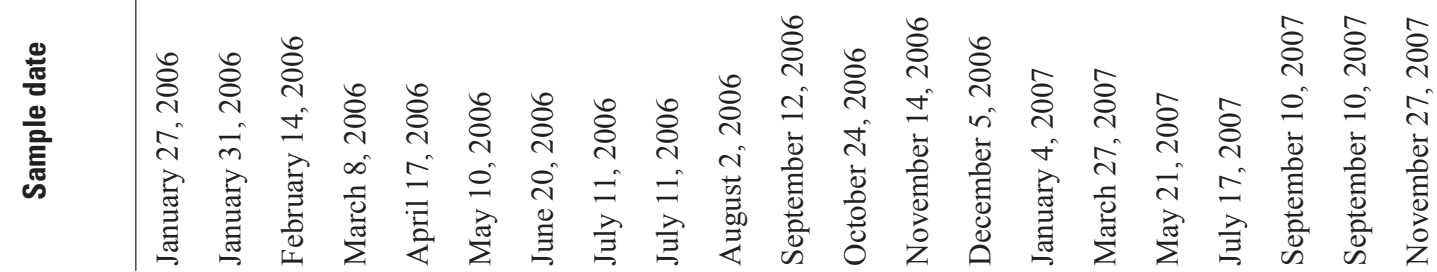




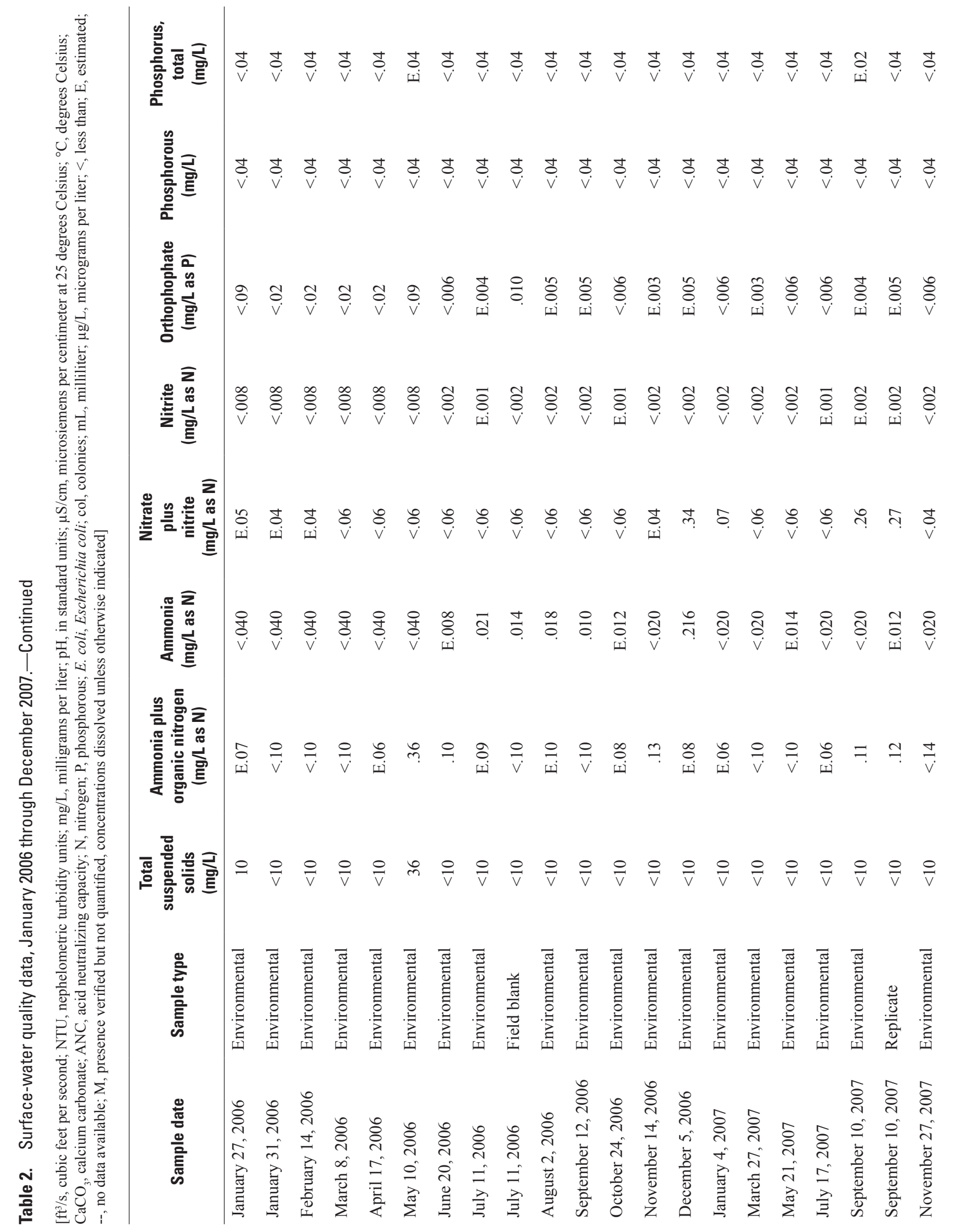




$$
\begin{aligned}
& \text { 言莺 }
\end{aligned}
$$

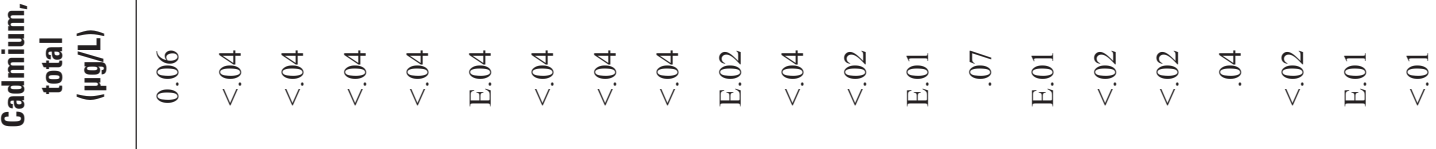

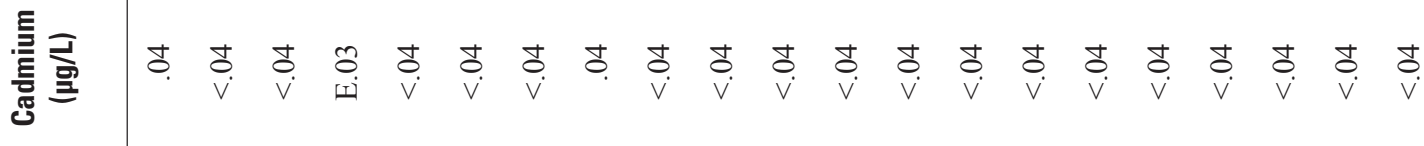

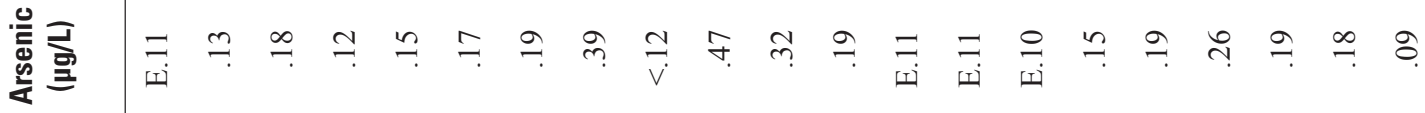

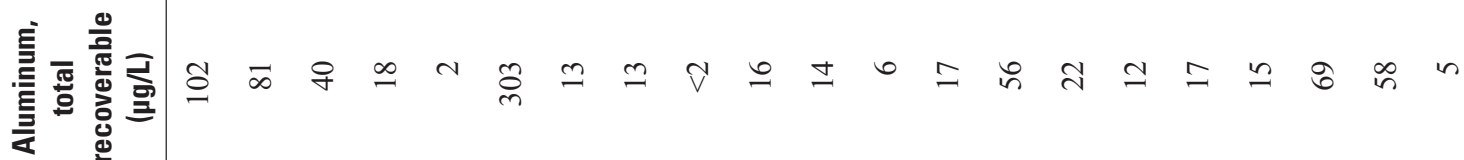

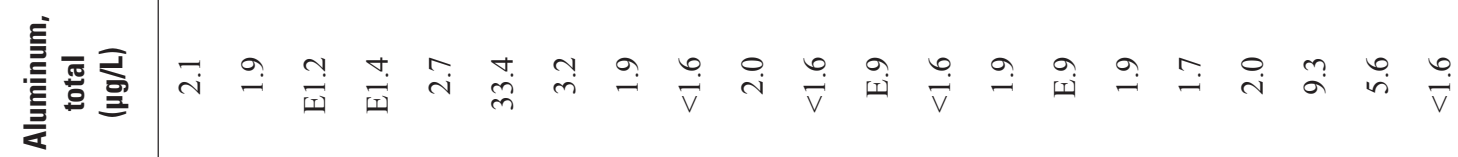

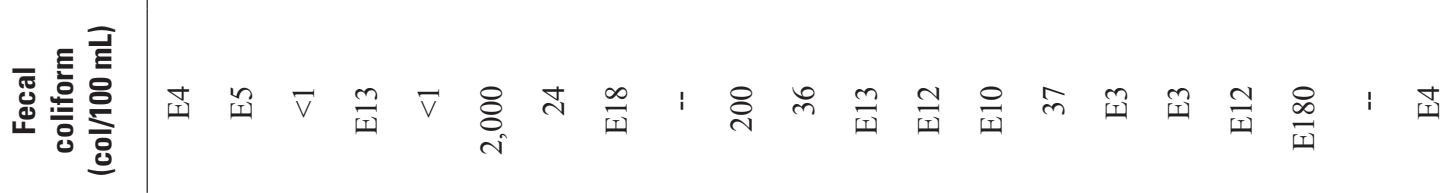

$$
\begin{aligned}
& \text { 容旁 }
\end{aligned}
$$

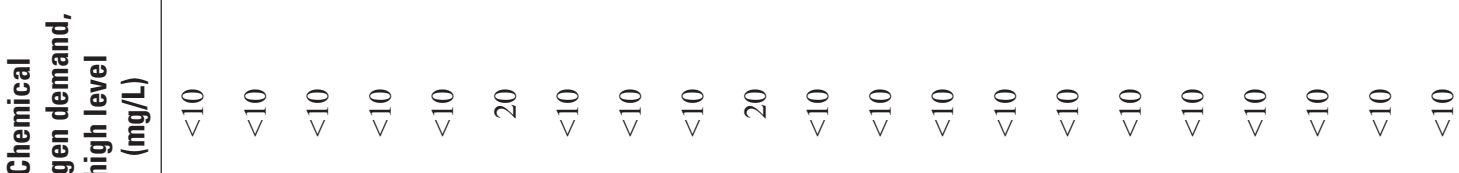

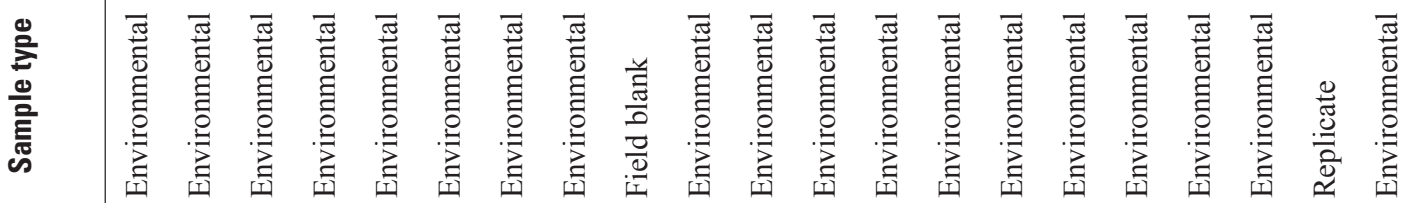

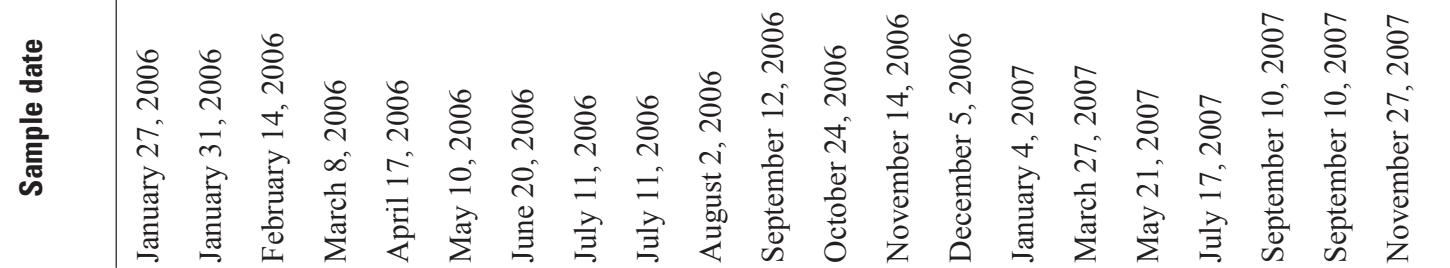




$$
\begin{aligned}
& \text { | }
\end{aligned}
$$

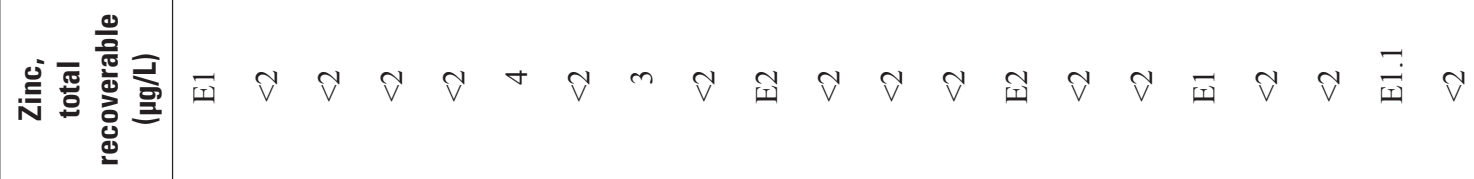

$$
\begin{aligned}
& \text { 号寻 号 } \\
& \text { 产 }
\end{aligned}
$$

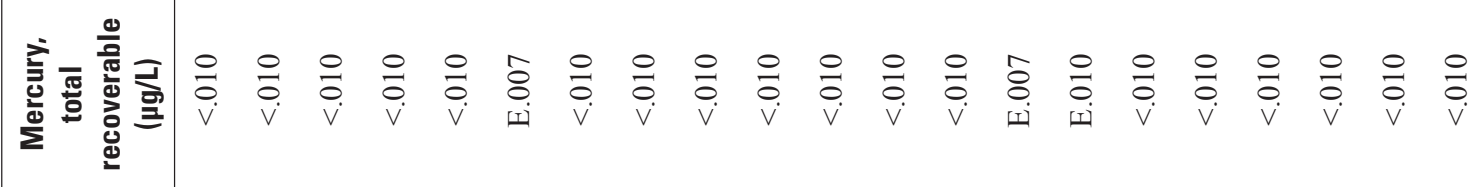

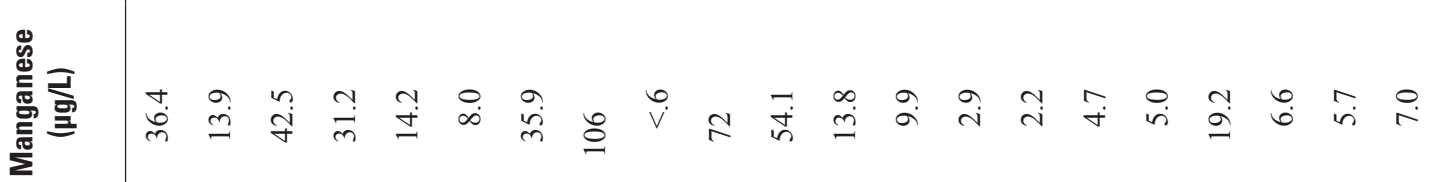

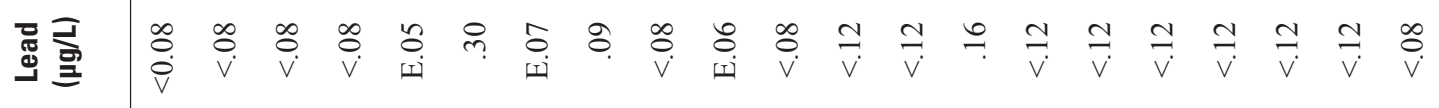




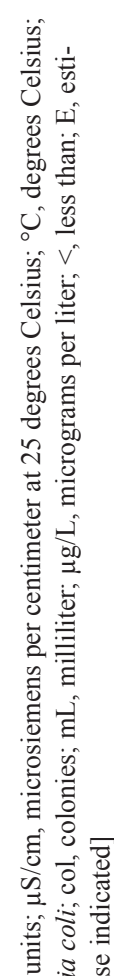

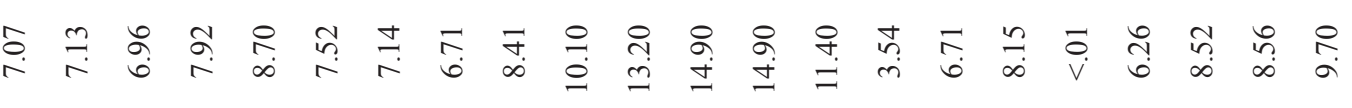

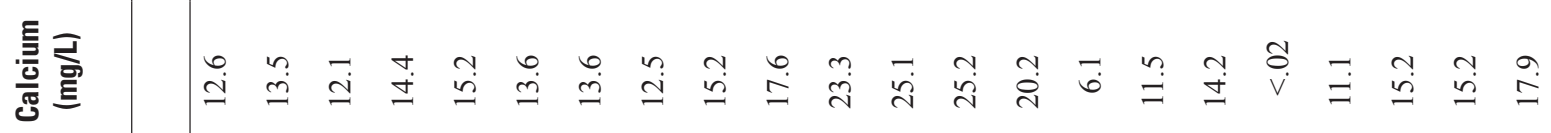

可

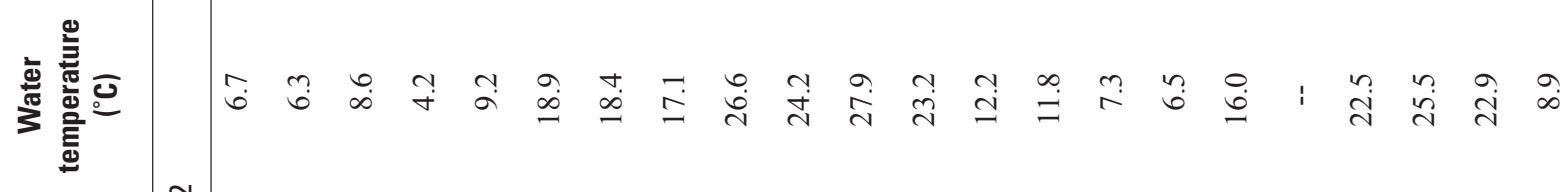

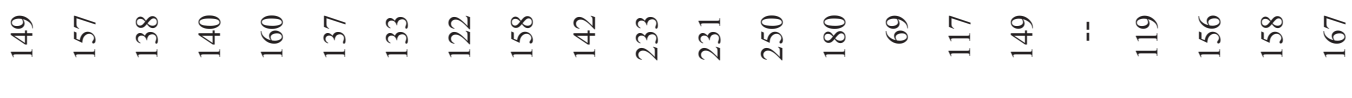

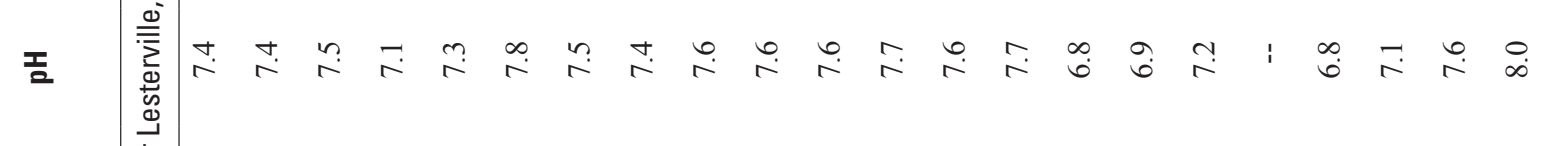

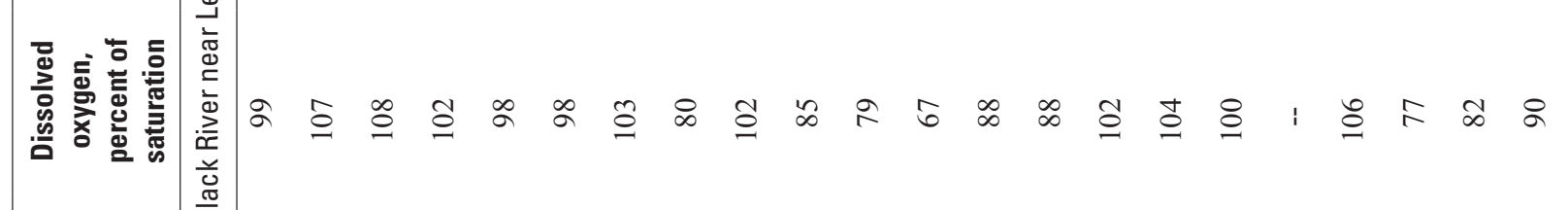

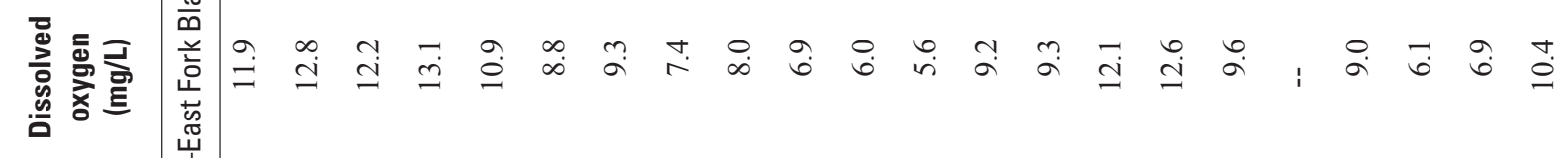

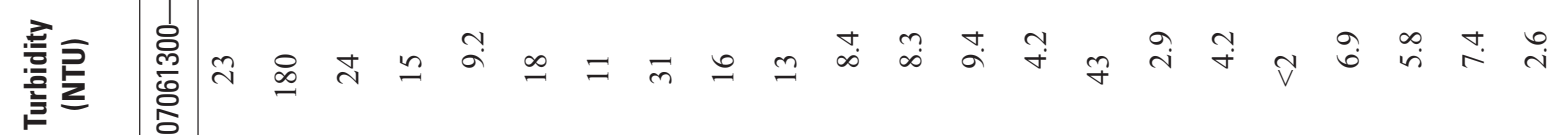
兽产 


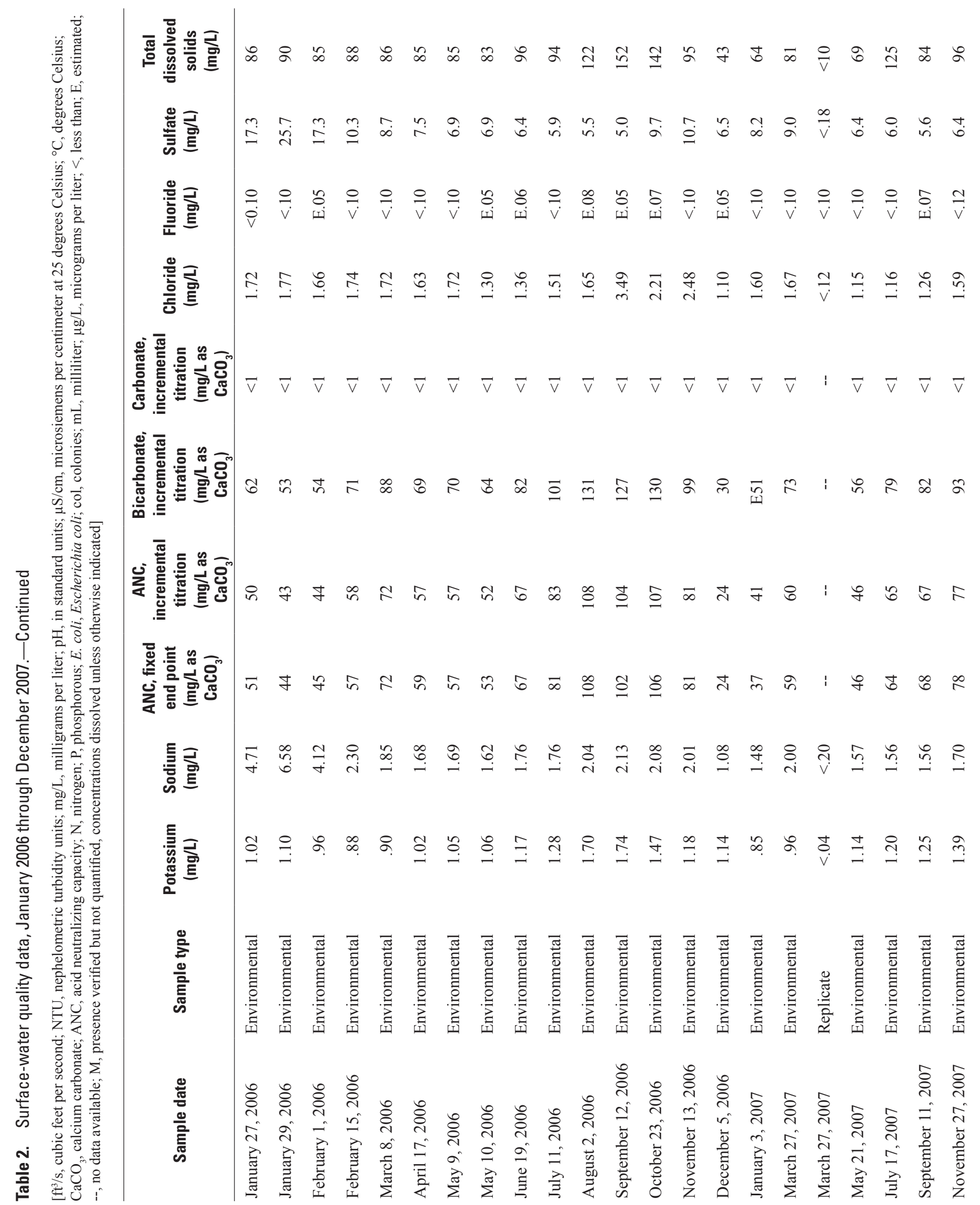




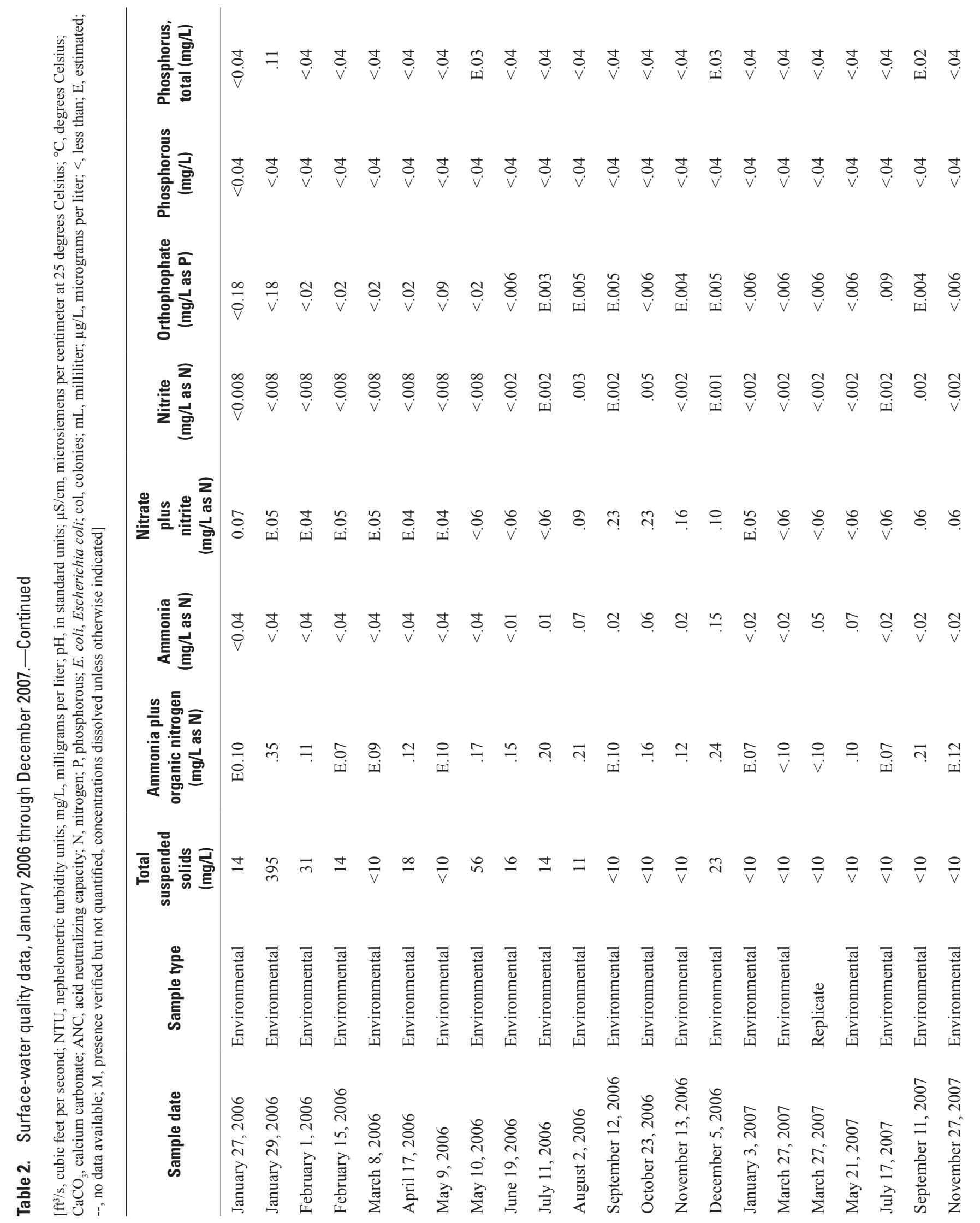




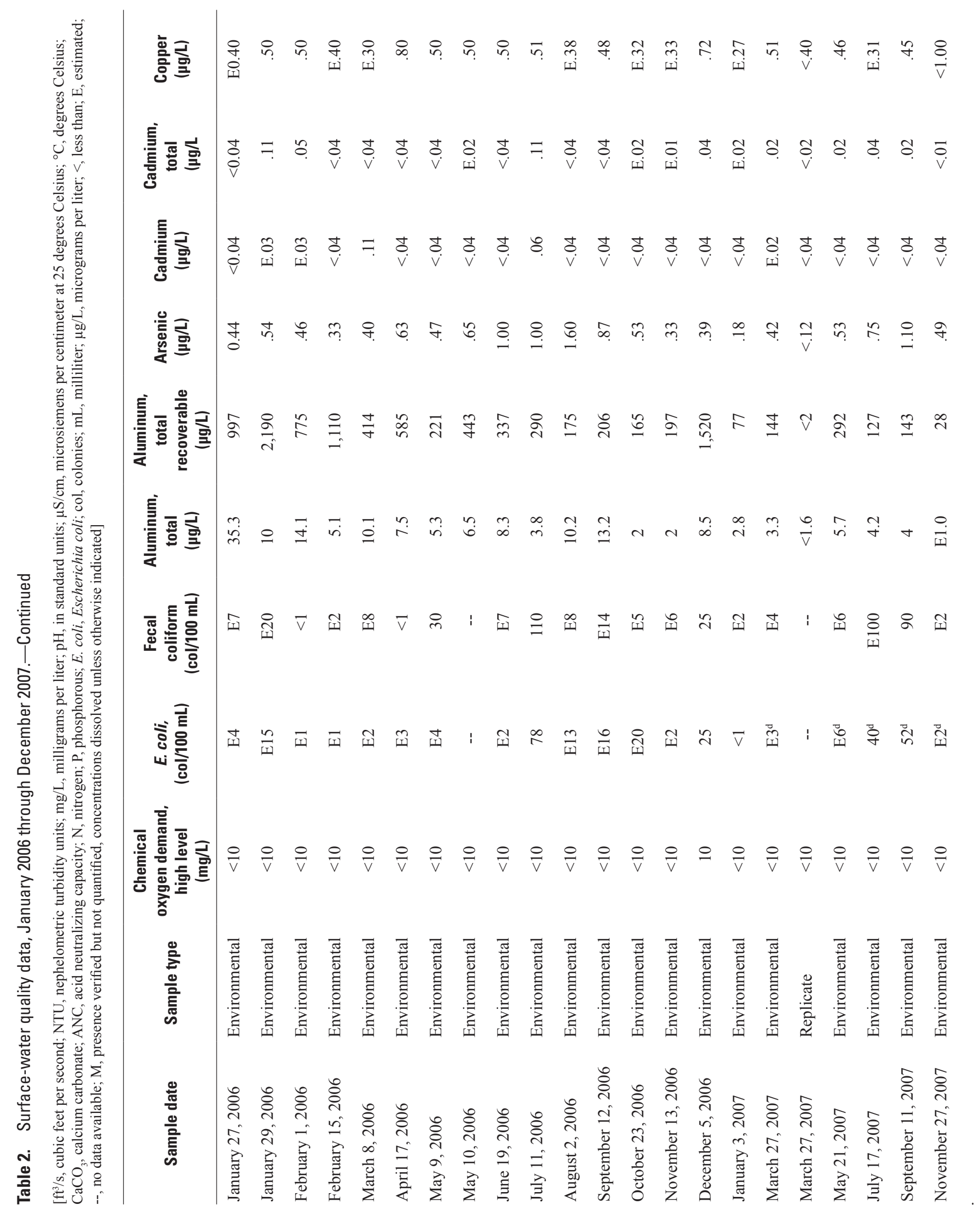




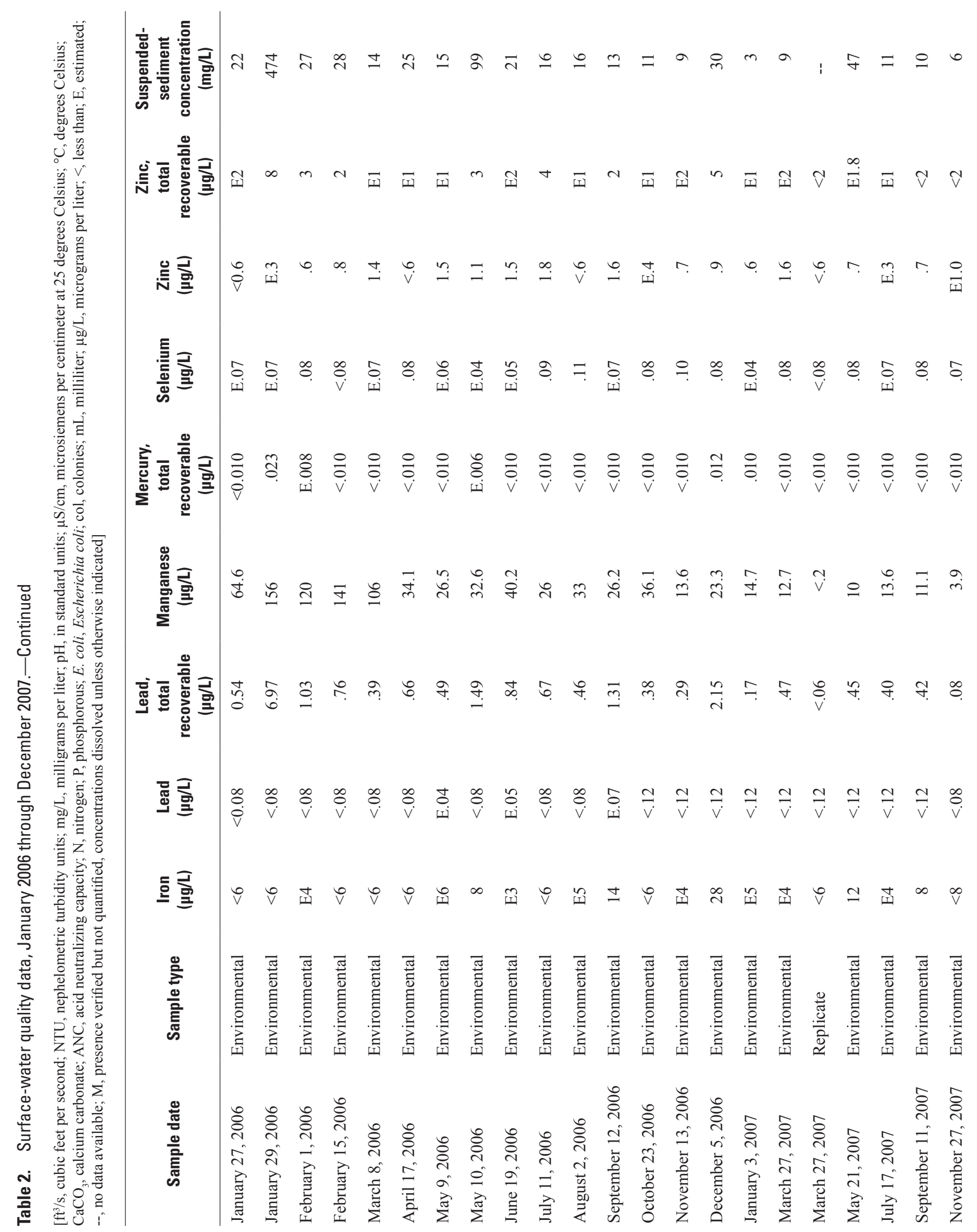




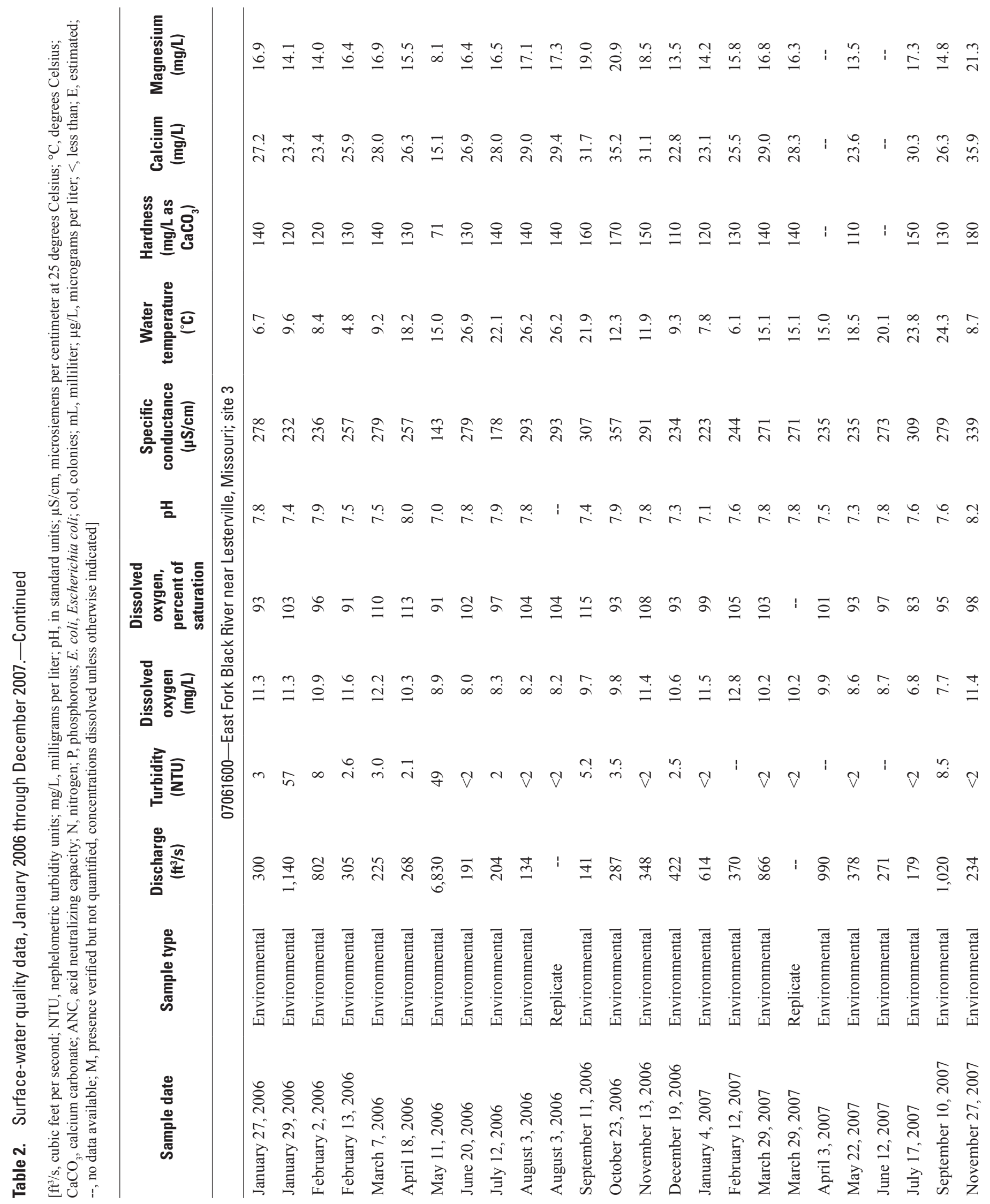




\section{蛋}

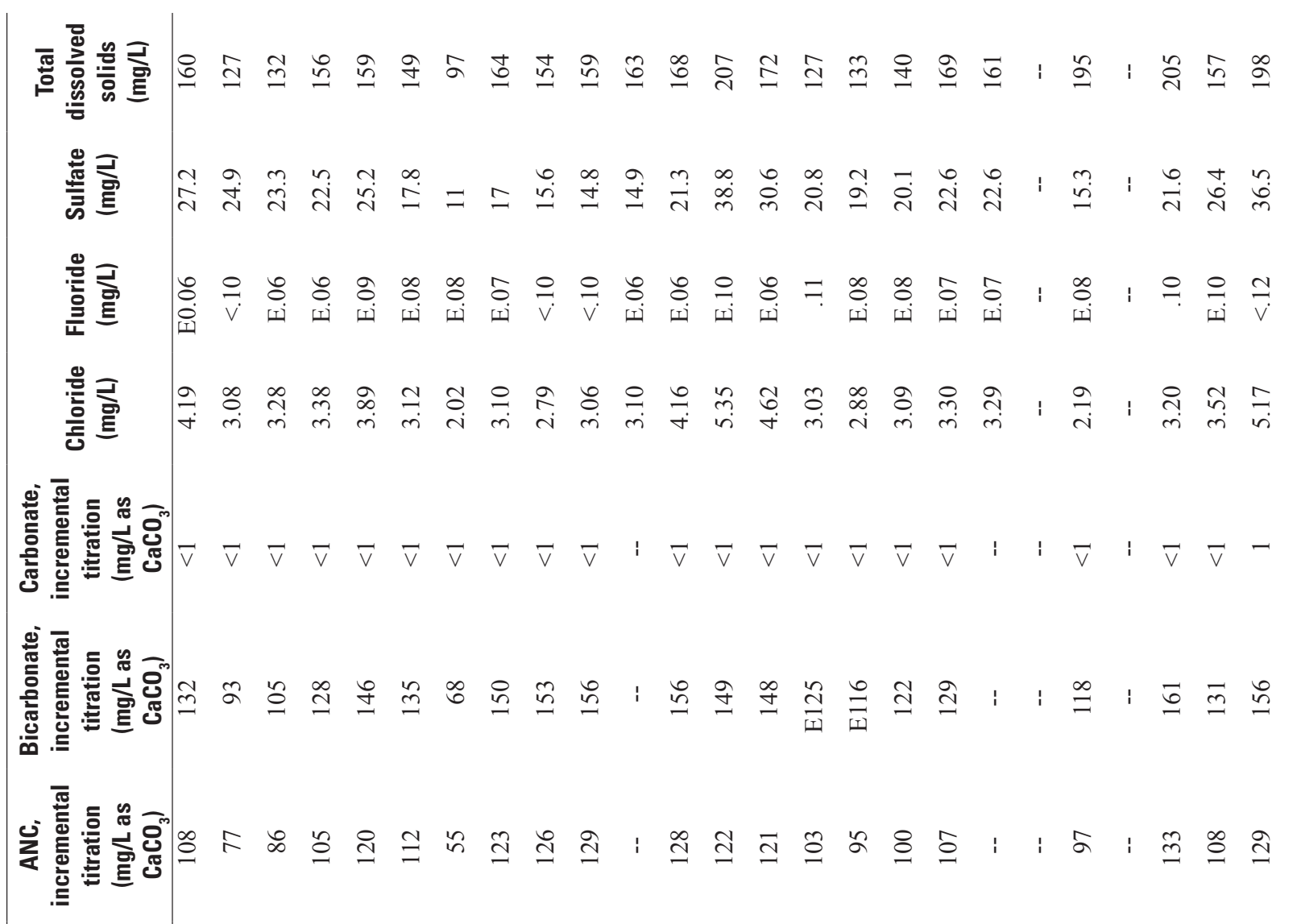

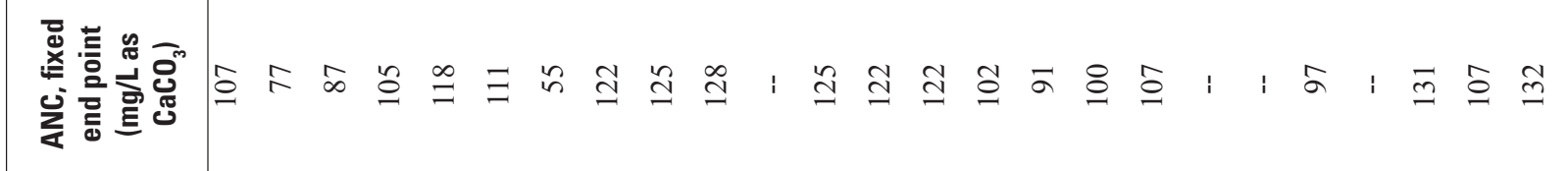

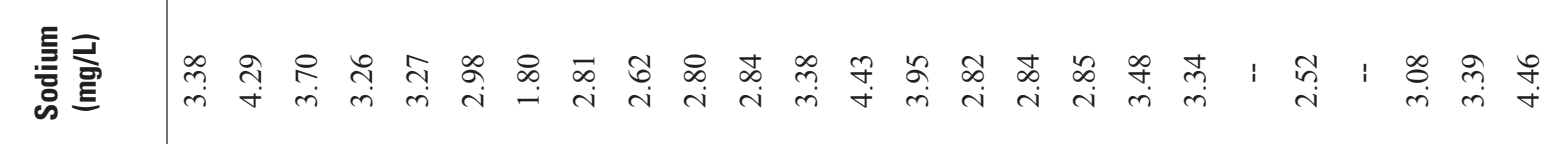
耪疋

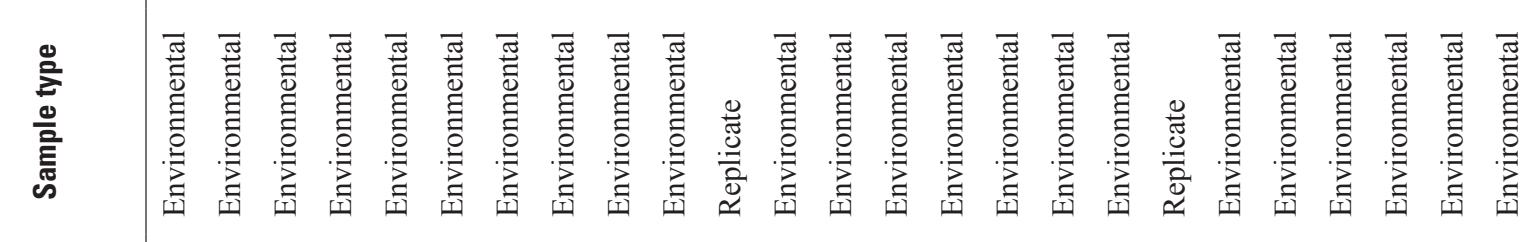
包艺 


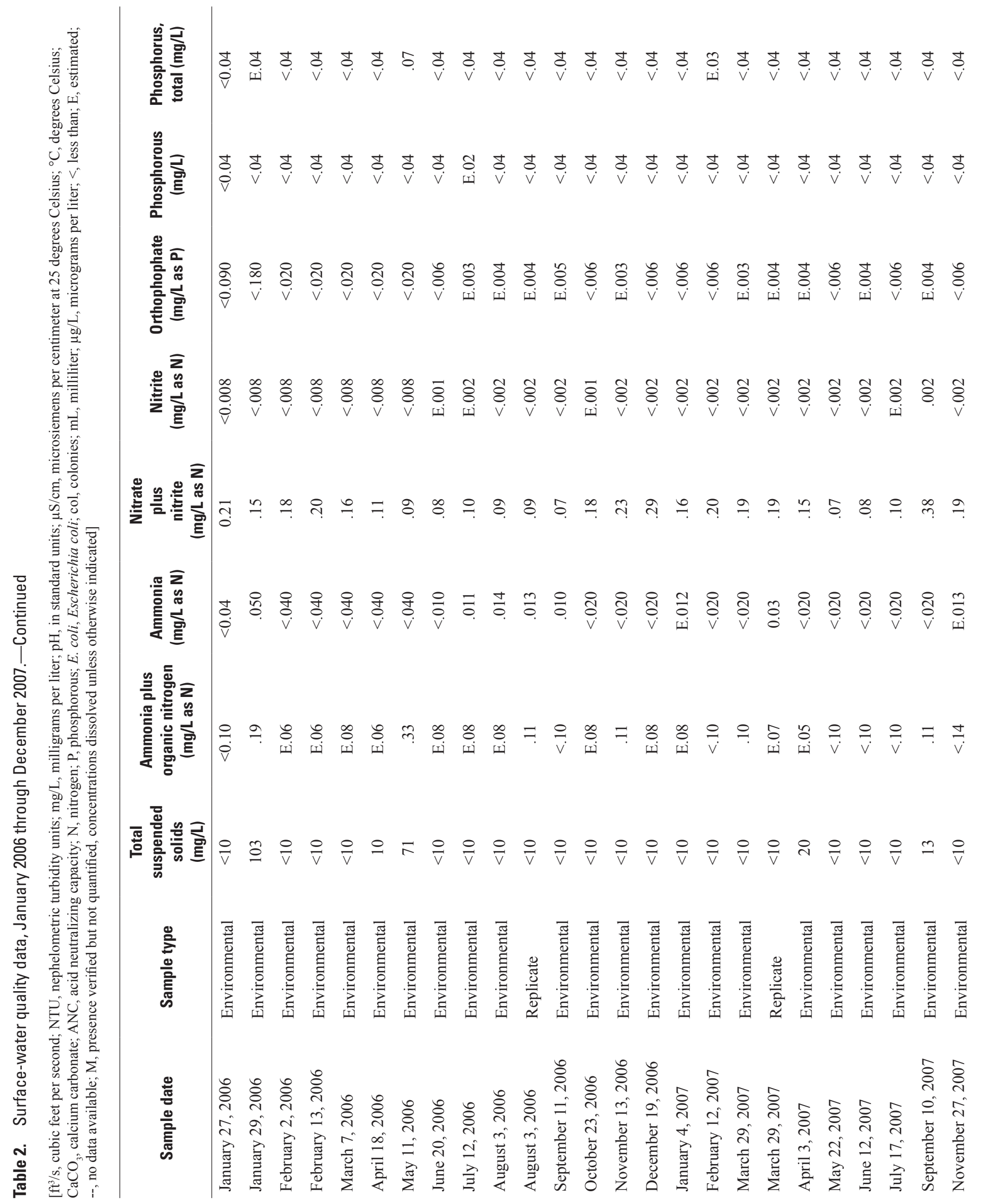




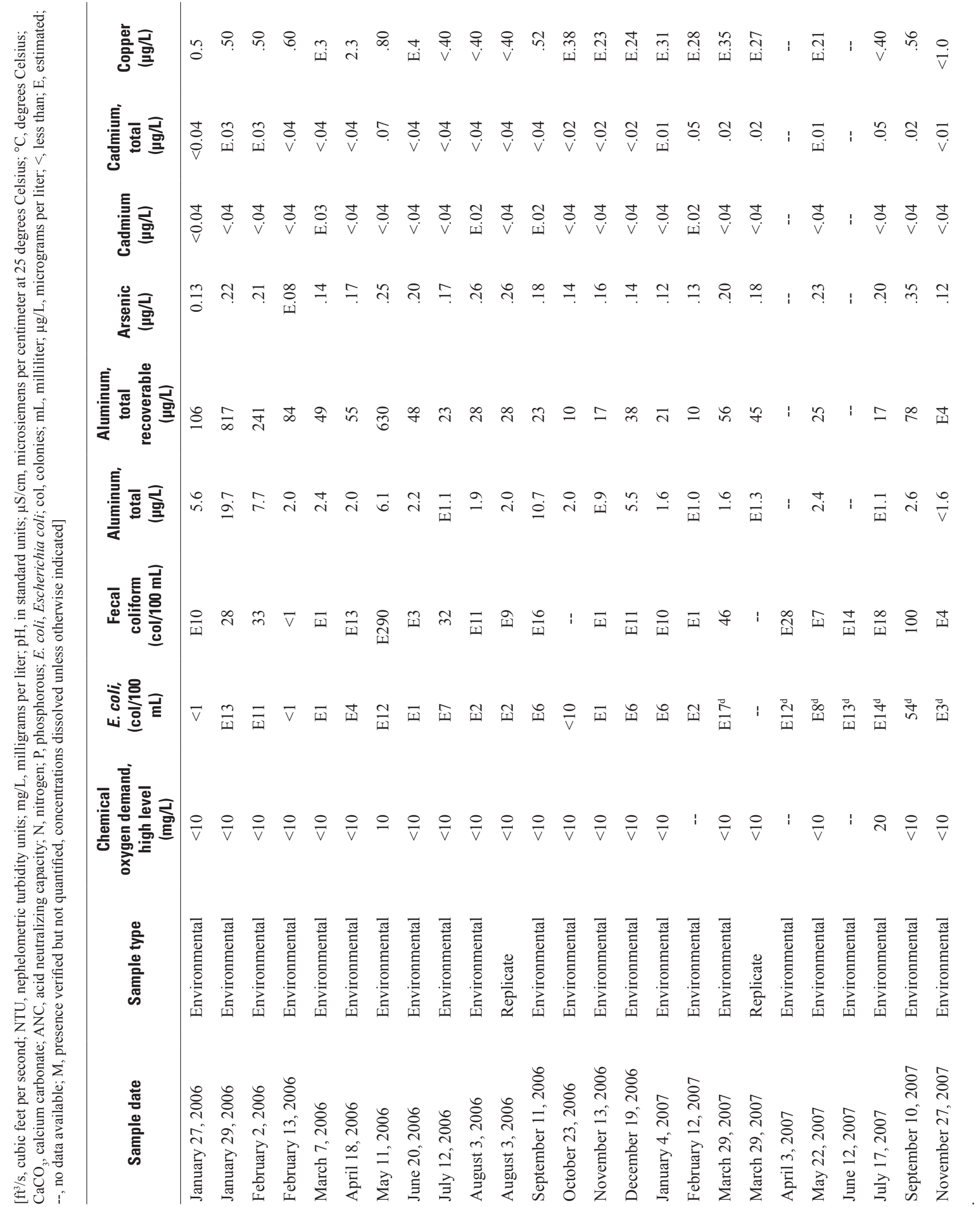




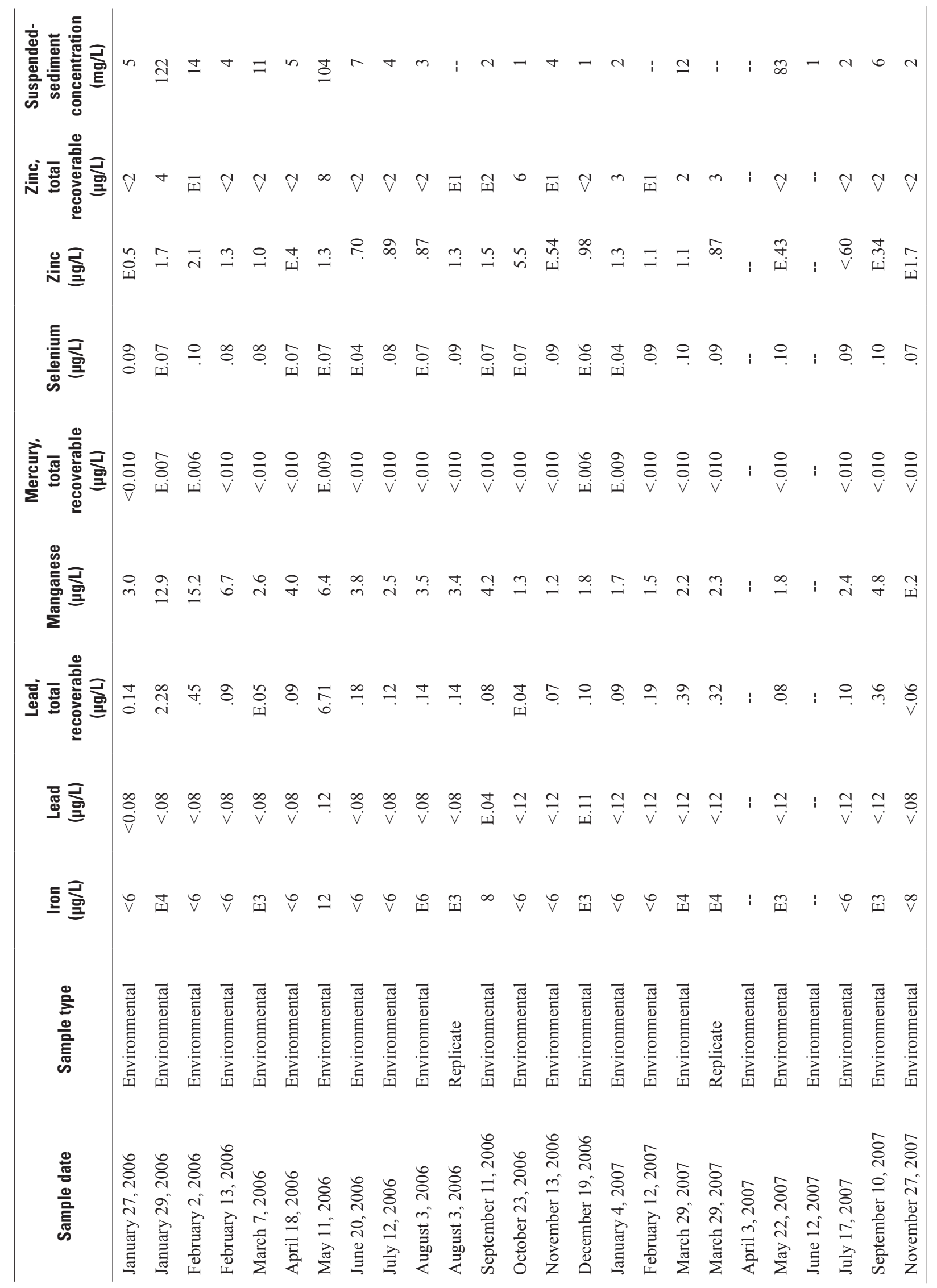




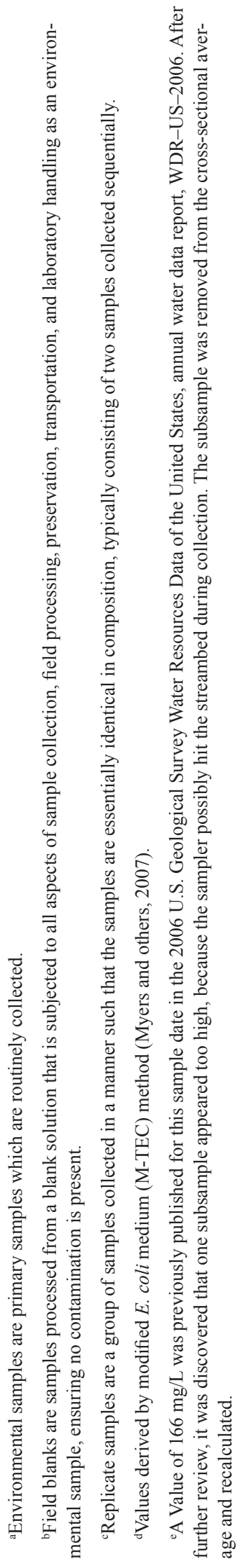


Publishing support provided by:

Rolla Publishing Service Center

For more information concerning this publication, contact:

Director

U.S. Geological Survey

Missouri Water Science Center

1400 Independence Road

Rolla, M0 65401

(573) 308-3667

Or visit the Missouri Water Science Center website at: http://mo.water.usgs.gov 

